Pacific Northwest National Laboratory

Operated by Battelle for the U.S. Department of Enery

\section{Facility Effluent Monitoring Plan for Pacific Northwest National Laboratory Balance-of-Plant Facilities}

March 1999

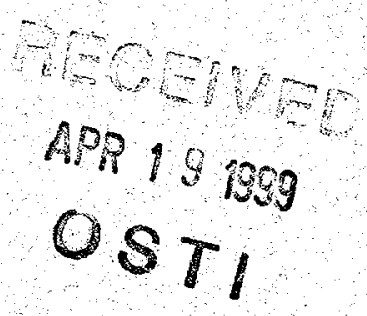

Prepared for the U.S. Department of Energy under Contract DE-AC06-76RLO 1830 


\section{Facility Effluent Monitoring Plan for Pacific Northwest National Laboratory Balance-of-Plant Facilities}

March 1999

Prepared for the U.S. Department of Energy under Contract DE-AC06-76RLO 1830

Pacific Northwest National Laboratory

Richland, Washington 99352 


\title{
DISCLAIMER
}

This report was prepared as an account of work sponsored by an agency of the United States Government. Neither the United States Government nor any agency thereof, nor Battelle Memorial Institute, nor any of their employees, makes any warranty, express or implied, or assumes any legal liability or responsibility for the accuracy, completeness, or usefulness of any information, apparatus, product, or process disclosed, or represents that its use would not infringe privately owned rights. Reference herein to any specific commercial product, process, or service by trade name, trademark, manufacturer, or otherwise does not necessarily constitute or imply its endorsement, recommendation, or favoring by the United States Government or any agency thereof, or Battelle Memorial Institute. The views and opinions of authors expressed herein do not necessarily state or reflect those of the United States Government or any agency thereof.

\author{
PACIFIC NORTHWEST NATIONAL LABORATORY \\ operated by \\ BATTELLE \\ for the \\ UNITED STATES DEPARTMENT OF ENERGY \\ under Contract DE-AC06-76RLO 1830
}

\author{
Printed in the United States of America \\ Available to DOE and DOE contractors from the \\ Office of Scientific and Technical Information, P.O. Box 62, Oak Ridge, TN 37831; \\ prices available from (615) $576-8401$. \\ Available to the public from the National Technical Information Service, \\ U.S. Department of Commerce, 5285 Port Royal Rd., Springfield, VA 22161
}




\section{DISCLAIMER}

Portions of this document may be illegible in electronic image products. Images are produced from the best available original document. 
Environmental Management Services

\section{FACILITY EFFLUENT MONITORING PLAN FOR PACIFIC NORTHWEST NATIONAL LABORATORY BALANCE-OF-PLANT FACILITIES}

Prepared by:

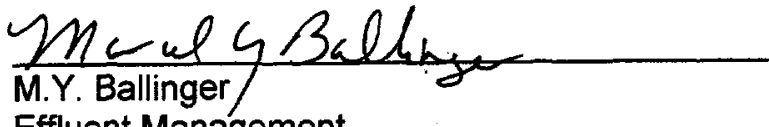

Effluent Management

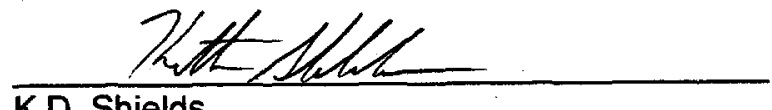

Effluent Management

Approved for Use and Application by:
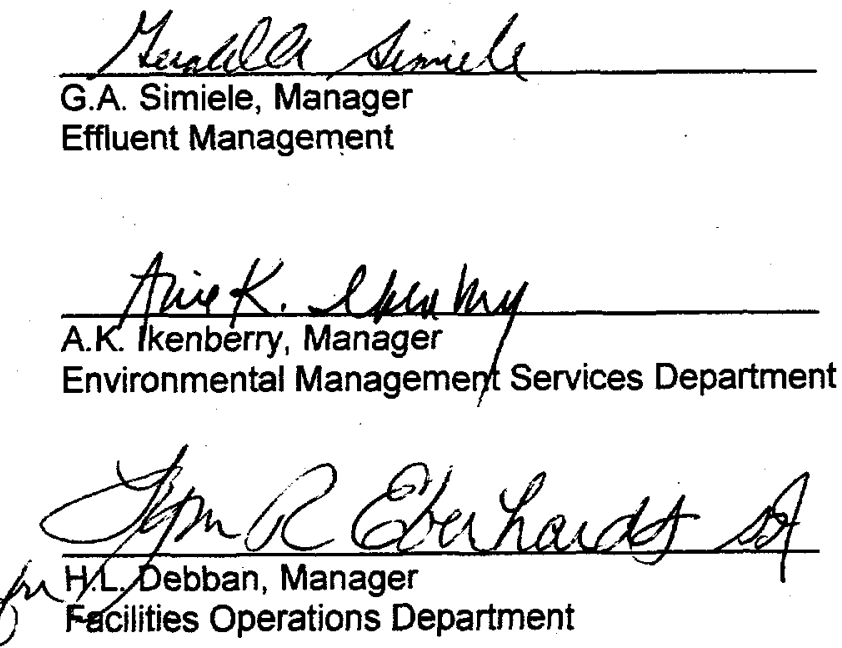

Pacific Northwest National Laboratory

Operated by Battelle for the

U. S. Department of Energy 


\section{Summary}

The Pacific Northwest National Laboratory (PNNL) operates a number of research and development (R\&D) facilities for the Department of Energy on the Hanford Site. According to DOE Order 5400.1, a Facility Effluent Monitoring Plan is required for each site, facility, or process that uses, generates, releases, or manages significant pollutants or hazardous materials. Three of the R\&D facilities: the 325 , 331 , and 3720 Buildings, are considered major emission points for radionuclide air sampling and thus individual Facility Effluent Monitoring Plans (FEMPs) have been developed for them. Because no definition of "significant" is provided in DOE Order 5400.1 or the accompanying regulatory guide DOE/EH-0173T, this FEMP was developed to describe monitoring requirements in the DOE-owned, PNNL-operated facilities that do not have individual FEMPs. The remainder of the DOE-owned, PNNLoperated facilities are referred to as Balance-of-Plant (BOP) facilities.

Activities in the BOP facilities range from administrative to laboratory and pilot-scale R\&D. R\&D activities include both radioactive and chemical waste characterization, fluid dynamics research, mechanical property testing, dosimetry research, and molecular sciences. The mission and activities for individual buildings are described in the FEMP.

Potential radioactive airborne emissions in the BOP facilities are estimated annually using a building inventory-based approach. The methods used are derived from 40 CFR 61 Appendix D. Sampling at individual BOP facilities is based on the potential to emit assessment. Some of these facilities are considered minor emission points and thus are sampled routinely, but not continuously, to confirm the low emission potential. Sampling systems are located downstream of control technologies and just prior to discharge to the atmosphere.

The need for monitoring airborne emissions of hazardous chemicals is established in the Hanford Site Air Operating Permit and in Notices of Construction. Based on the current potential-to-emit, the permit does not contain general monitoring requirements for BOP facilities. However, the permit identifies monitoring requirements for specific projects and buildings. Needs for future monitoring will be established by future permits issued pursuant to the applicable state and federal regulations.

A number of liquid effluent discharge systems serve the BOP facilities: sanitary sewer, process sewer, and retention process sewer. None of these systems discharge to the environment; they all either discharge to treatment plants or to long term storage. Routine compliance sampling of liquid effluents is only required at the Environmental Molecular Sciences Laboratory. Liquid effluents from other BOP facilities may be sampled or monitored to characterize facility effluents or to investigate discharges of concern. Liquid effluent characterization data is summarized in the FEMP.

Effluent sampling and monitoring for the BOP facilities depends on the inventories, activities, and environmental permits in place for each facility. A description of routine compliance monitoring for BOP facilities is described in the BOP FEMP. 
This page intentionally left blank. 


\section{Contents}

Page No.

Summary i

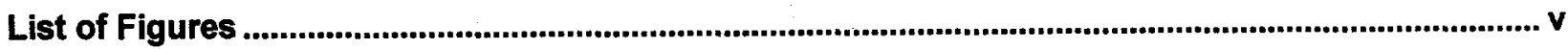

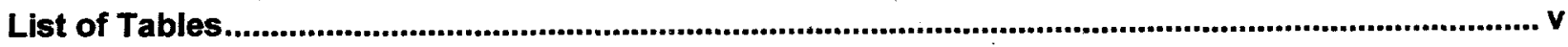

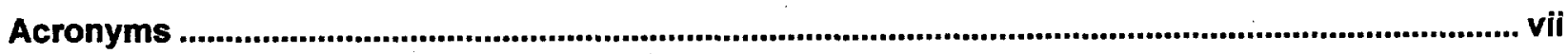

1.0 INTRODUCTION .........................................................................................1.1

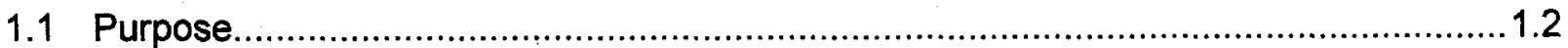

1.2 Scope

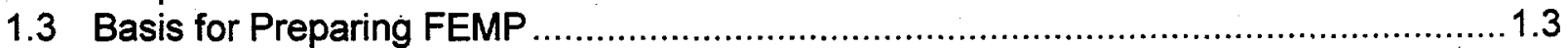

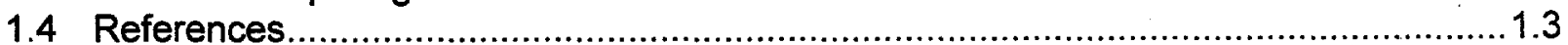

2.0 FACILITY DESCRIPTION ............................................................................2.1

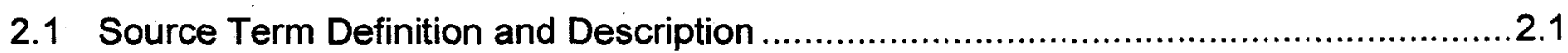

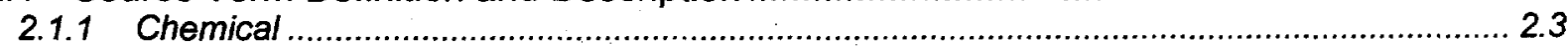

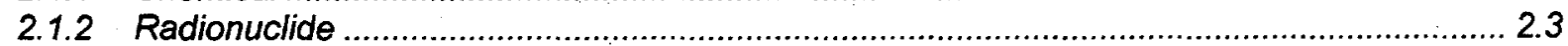

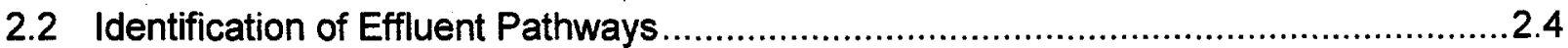

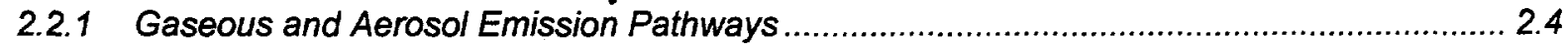

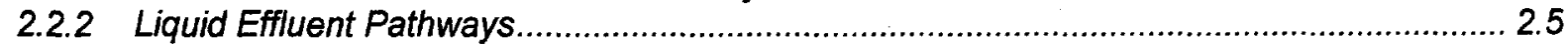

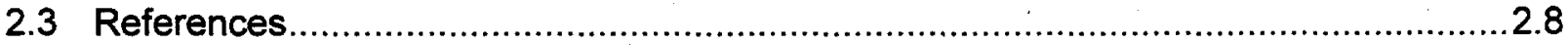

\subsection{RATIONALE AND DESIGN CRITERIA FOR SAMPLING AND MONITORING .3.1}

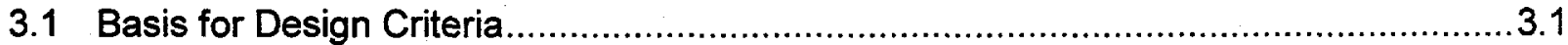

3.2 Criteria for Radiological Air Emission Sampling \& Monitoring ....................................

3.2.1 Sampling System Performance Criteria ....................................................................... 3.3

3.2.2 Sampling System Design Criteria .................................................................................... 3.3

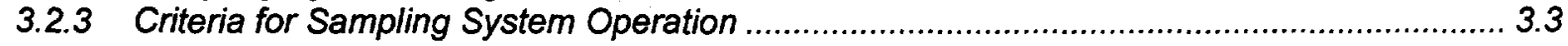

3.3 Historical Sampling Data for Effluent Streams ....................................................

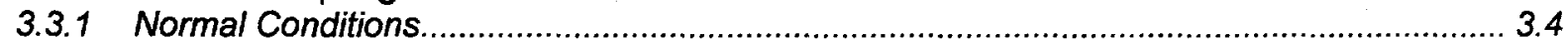

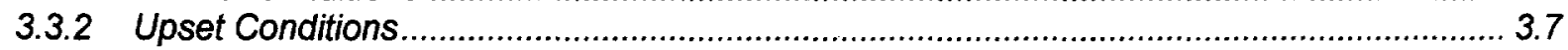

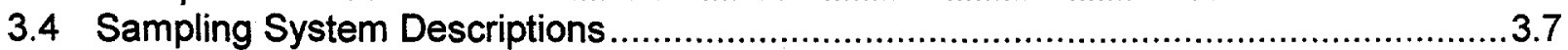

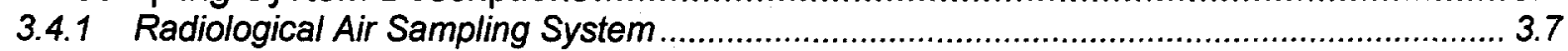

3.4.2 Criteria for Air Chemical Emission Sampling ............................................................... 3.9

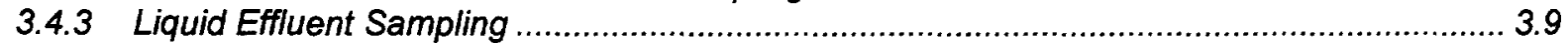

3.5 Sampling System Performance ...................................................................... 12

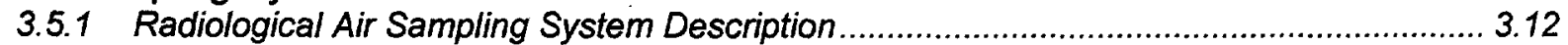

3.6 Handling of Sampling Data............................................................................. 3.12

3.7 Calibration and Maintenance of Equipment ..................................................... 3.13

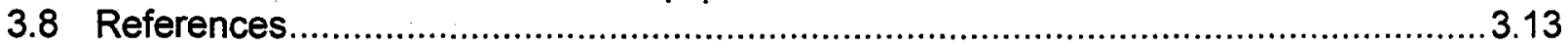

4.0 LABORATORY ANALYSES .....................................................................4.1

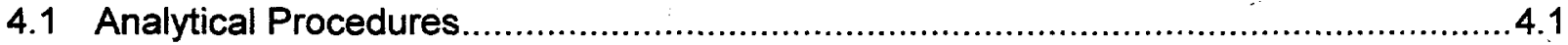

4.1.1 Determination of Alpha and Beta Activity on Particulate Air Filters ................................. 4.1

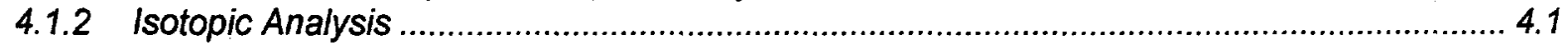

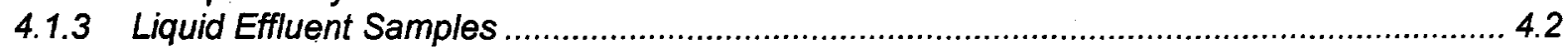

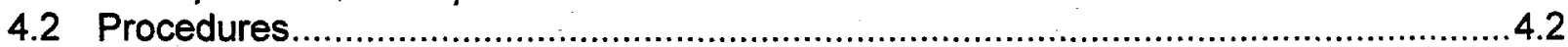

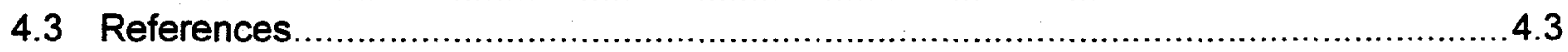


5.0 QUALITY ASSURANCE REQUIREMENT

5.1 Quality Assurance Plan

5.2 Internal and External Plan Review..

5.3 References

6.0 PROGRAM IMPLEMENTATION PROCEDURES.............................................

6.1 Interface with the Near-facility Environmental Monitoring Program .............................6.1

6.2 Interface with the Operational Environmental Surveillance Program ...........................6.1

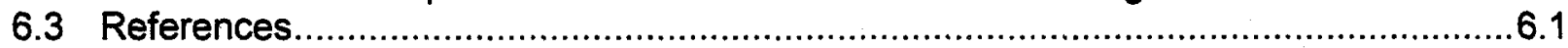

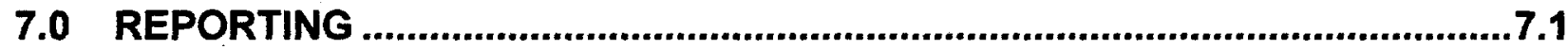

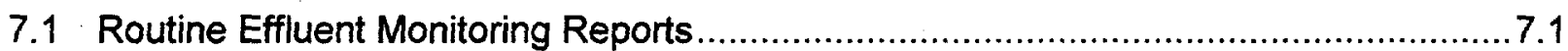

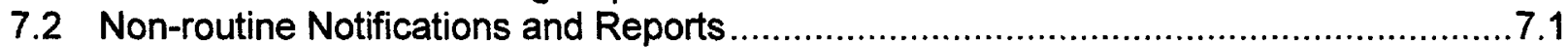

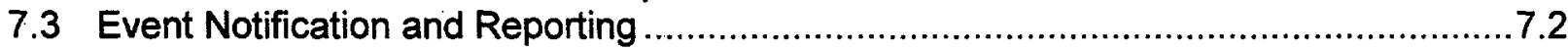

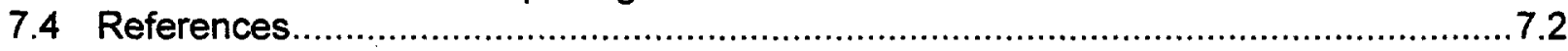

APPENDIX A - INFORMATION ON CURRENT BALANCE OF PLANT FACILITIES

APPENDIX B - SUPPORTING CALCULATIONS 


\section{Figures}

2.1 ActiveDOE-owned, PNNL-operated Facilities in the 300 Area of Hanford ................................ 2.2

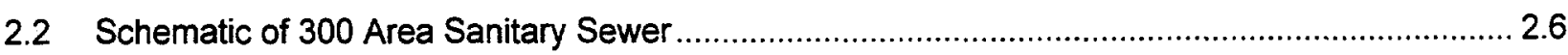

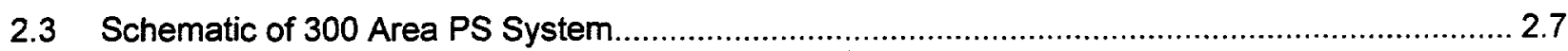

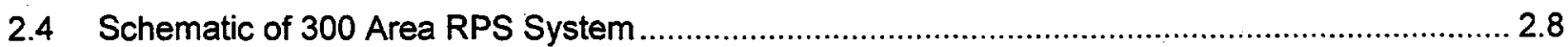

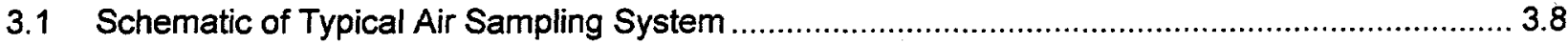

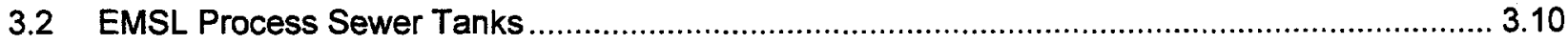

3.3 Location of the 320 Liquid Effluent Sampling and Monitoring System .................................... 3.11

3.4 Location of the 326 and 329 Liquid Effluent Sampling and Monitoring System ....................... 3.11

\section{Tables}

3.1 Radionuclide Air Emissions from BOP Facilities

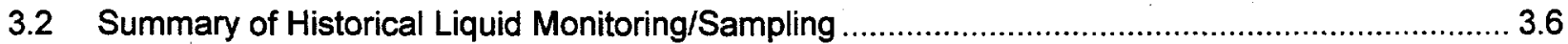

3.3 Off-Normal and Unusual Occurrences in the BOP Facilities .................................................... 3.7

3.4 Detectable Activity from BOP Minor Emission Points ........................................................... 3.12

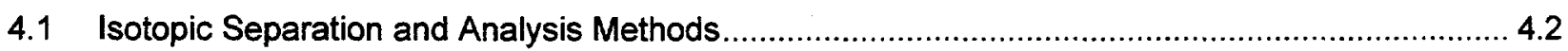


This page intentionally left blank. 


\section{ACRONYMS}

ALE - Fitzner/Eberhardt Arid Lands Ecology Reserve

AMAD - Activity Median Aerodynamic Diameter

ANSI - American National Standards Institute

BCAA - Benton Clean Air Authority

BOP - Balance of Plant

CMS - Chemical Management System

COC - Chain of Custody

DEPO - Deposition Code

DMR - Discharge Monitoring Report

DOE - Department of Energy

DOE/RL - Department of Energy Richland Operations Office

EMP - Environmental Monitoring Plan

EMSL - Environmental Molecular Sciences Laboratory

EPA - Environmental Protection Agency

FEMP - Facility Effluent Monitoring Plan

FUA - Facility Use Agreement

GED - Gaseous Effluent Database

HEPA - High Efficiency Particulate Air

MBA - Material Balance Area

MDA - Minimum Detectable Activity

NESHAP - National Emission Standards for Hazardous Air Pollutants

NOC - Notice of Construction

OED - Offsite Emission Dose

ONE - Off-Normal Event

ONO - Off-Normal Occurrence

PNNL - Pacific Northwest National Laboratory

POTW - Publicly Owned Treatment Works

PS - Process Sewer

QA - Quality Assurance

QC - Quality Control

R\&D - Research and Development

RAT - Radioanalytical Application Team

RIDS - Records Inventory and Disposition Schedule

RLWS - Radioactive Liquid Waste System

RPS - Retention Process Sewer

$R Q$ - Reportable Quantity

SAR - Safety Analysis Report

SBMS - Standards Based Management System

SNM - Special Nuclear Material

SNS - Sanitary Sewer

SOP - Standard Operating Procedure

TEDF - Treated Effluent Disposal Facility

UO - Unusual Occurrence

WDOH - Washington State Department of Health

WMHC - Waste Management Hanford Company 
This page intentionally left blank. 


\subsection{Introduction}

It is the policy of the U.S. Department of Energy (DOE) and the Pacific Northwest National Laboratory (PNNL) to monitor effluents to determine if the public and the environment are adequately protected during DOE operations and whether operations are in compliance with DOE and other applicable federal, state, and local standards and requirements. It is also DOE and DOE-contractor policy that effluent monitoring programs meet high standards of quality and credibility.

\subsection{Purpose}

DOE Order 5400.1 (DOE 1988), "General Environmental Protection Programs" states the following objective for environmental monitoring programs:

demonstrate compliance with legal and regulatory requirements imposed by applicable Federal, State, and local agencies; confirm adherence to DOE environmental protection policies; and support environmental management decisions (Section IV-1).

Plans must be prepared for each site, facility, or process that uses "significant pollutants or hazardous materials" (DOE 1988, Section, IV-2). These requirements are being met through the environmental monitoring program conducted for the Hanford Site and described by the DOE Richland Operations Office (DOE/RL) in the Hanford Site Environmental Monitoring Plan (EMP) (DOE 1997).

The EMP identifies and discusses two major activities as specified by DOE 5400.1: a) effluent monitoring and $b$ ) environmental surveillance. Because the Hanford Site contains a number of facilities with effluent monitoring needs, individual effluent-monitoring plans are prepared for those facilities to support the discussion of effluent monitoring in the EMP. Individual facility effluent monitoring plans (Facility Effluent Monitoring Plans [FEMPs]) were prepared for the following PNNL-operated facilities primarily because these facilities have "major" (potential to emit of $>0.1 \mathrm{mrem} / \mathrm{yr}$ ) emission points for radionuclide air emissions according to the annual National Emission Standards for Hazardous Air Pollutants (NESHAP) assessment performed in 1997. These "major" facilities are: 325,331 , and 3720 . FEMPs are prepared for those facilities to implement the effluent monitoring requirements found in the EMP. This report supplies information on effluent monitoring in all DOE-owned, PNNL-operated facilities other than 325 , 331 , and 3720. A complete listing of these Balance-of-Plant (BOP) facilities is provided in Appendix A. Facilities that are inactive or used only for administrative purposes (office buildings) are listed in Appendix $A$, but are not required to be monitored, so are not addressed further. The information provided in this FEMP is current as of the time of FEMP issuance. DOE Order 5400.1 requires the EMP to be reviewed annually and updated every 3 years. Update of this FEMP will also occur on a 3 year schedule.

\subsection{Scope}

Characterizing the radioactive and nonradioactive constituents in inventories and in waste streams provides the underlying rationale for sampling and monitoring programs. Currently, confirmatory sampling for radionuclide air emissions is required for some of the BOP facilities. Routine sampling for air chemical emissions is not required for any of these facilities. However, confirmatory sampling of total carbon from some BOP stacks is conducted as required to confirm calculations submitted in permit applications or notices of construction (NOCs). For liquid waste streams, Waste Management Hanford Company (WMHC) performs compliance sampling of process liquid waste streams, and DynCorp performs compliance sampling of sanitary sewer discharges, as required, from the 300 Area (except the Environmental Molecular Sciences Laboratory [EMSL]). PNNL performs compliance sampling for process liquid streams discharged from EMSL. No routine liquid-effluent monitoring is required for DOEowned, PNNL-operated facilities in other areas.

A major activity of the FEMP effort is to identify the liquid and air release pathways (e.g., identify all access points to the various sewers and all radioactive emission release pathways) under normal operations and during process upset conditions. These are verified on as-built drawings that are maintained in PNNL's Essential Drawings System. This verification was performed for the following BOP facilities because they have the greatest potential for environmental release based on their radioactive or chemical inventories: 306-W (ventilation drawings), 326 and 329 (ventilation and effluent piping drawings). 
The method of characterization discussed in this plan identifies potential pollutants at the point of generation and potential upset conditions that are likely to occur, and evaluates the potential for those materials to enter an effluent stream.

\subsection{Basis for Preparing FEMP}

A FEMP is required for each site, facility, or process that uses, generates, releases, or manages significant pollutants or hazardous materials. No definition of "significant" is provided in DOE Order 5400.1 (DOE 1988) or the accompanying regulatory guide DOE/EH-0173T (DOE 1991), so this BOP FEMP is prepared to describe monitoring requirements in the DOE-owned, PNNL-operated facilities that do not have individual FEMPs.

\subsection{References}

DOE 1988. General Environmental Protection Program, DOE 5400.1. United States Department of Energy Order. United States Department of Energy, Washington, D.C.

DOE 1991. Environmental Regulatory Guide for Radiological Effluent Monitoring and Environmental Surveillance, DOE/EH-0173T. United States Department of Energy Order. United States Department of Energy, Washington, D.C.

DOE 1997. Environmental Monitoring Plan, DOE/RL-91-50, Rev 2, United States Department of Energy, Richland Operations Office, Richland, Washington. 


\subsection{Facility Description}

Facility use and mission may change, and modifications may be made that significantly affect effluent monitoring. Therefore, this section will discuss the range of physical descriptions, missions, activities that generate effluents, and effluent pathways for all DOE-owned, PNNL-operated facilities. A listing of the BOP facilities at the time of writing this FEMP is provided in Appendix A along with more detailed information on these facilities.

DOE-owned, PNNL-operated facilities are located primarily in the 300 Area of Hanford (see Figure 2.1). These range from small storage facilities to multi-level high-bay research facilities. Over 50 facilities fall into the BOP category. Of these, a few buildings are office or administrative only, about one-quarter are research and development (R\&D) facilities, another one-quarter are R\&D support (e.g., storage, maintenance services, waste operations), and the rest are inactive.

The mission of the BOP facilities is to support the U.S. Department of Energy's Strategic Plan and Strategic Laboratory Mission Plan. In this plan, PNNL is designated as a principal laboratory in the environmental quality mission, a major contributing laboratory in both science and technology and energy, and a participating laboratory in national security. A majority of PNNL's work is in environmental science, environmental technology, or both. Also, the projects in support of DOE's national security and energy missions often draw heavily on capabilities PNNL has developed in support of the environmental mission.

Activities in individual facilities range from administrative to laboratory and pilot-scale R\&D. R\&D activities include both radioactive and chemical waste characterization, fluid dynamics research, mechanical property testing, and dosimetry research. R\&D work is performed on a project basis, and projects are evaluated for a number of factors, including environmental risk, before being initiated. Activities are evaluated for specific facilities through a preparatory and risk analysis process that includes reviewing the project activities against building current operational boundaries. Appendix $A$ gives a brief description of the type of work performed in individual active BOP facilities.

Facility Use Agreements (FUAs) have been prepared for most of the active BOP facilities. These FUAs describe the mission and activities for work in individual facilities and specify the limiting boundaries for facility operations. They also describe the physical structure and facility operating design parameters. In addition, facility drawings of BOP facilities are maintained through the PNNL F\&O Division. This division also manages facility modifications.

\subsection{Source Term Definition and Description}

The characteristics of releases that could contribute to each effluent stream during normal operating and upset conditions are described in this section. Unconfined contact with ventilation air is the only prerequisite for an inventory to contribute a gas or aerosol source term to the air-effluent stream. Thus, all "passive" inventories stored in open containers, as well as those used in "active" processes, can potentially produce gas or aerosol source terms. The following subsections discuss potential source terms under normal and upset ${ }^{\mathrm{a}}$ conditions.

The building and local inventories of radionuclides and toxic chemicals are important to effluent characterization because of their potential for release. This section provides information on the types and forms of chemicals and radionuclides in the BOP facilities under current and foreseen operations. For the purposes of this section, a source term is a description of the nature and location of potential sources of releases of radioactive and/or chemical materials within the building. The release could be to the atmosphere or the sewers due to process activities.

a The Environmental Regulatory Guide for Radiological Effluent Monitoring and Environmental Surveillance (DOE 1991) states that "provisions for monitoring of airborne emissions during accident situations should* be considered." The term "upsets" is used in this document to refer to accidents that might be expected to occur in a facility and for which monitoring should be considered. 


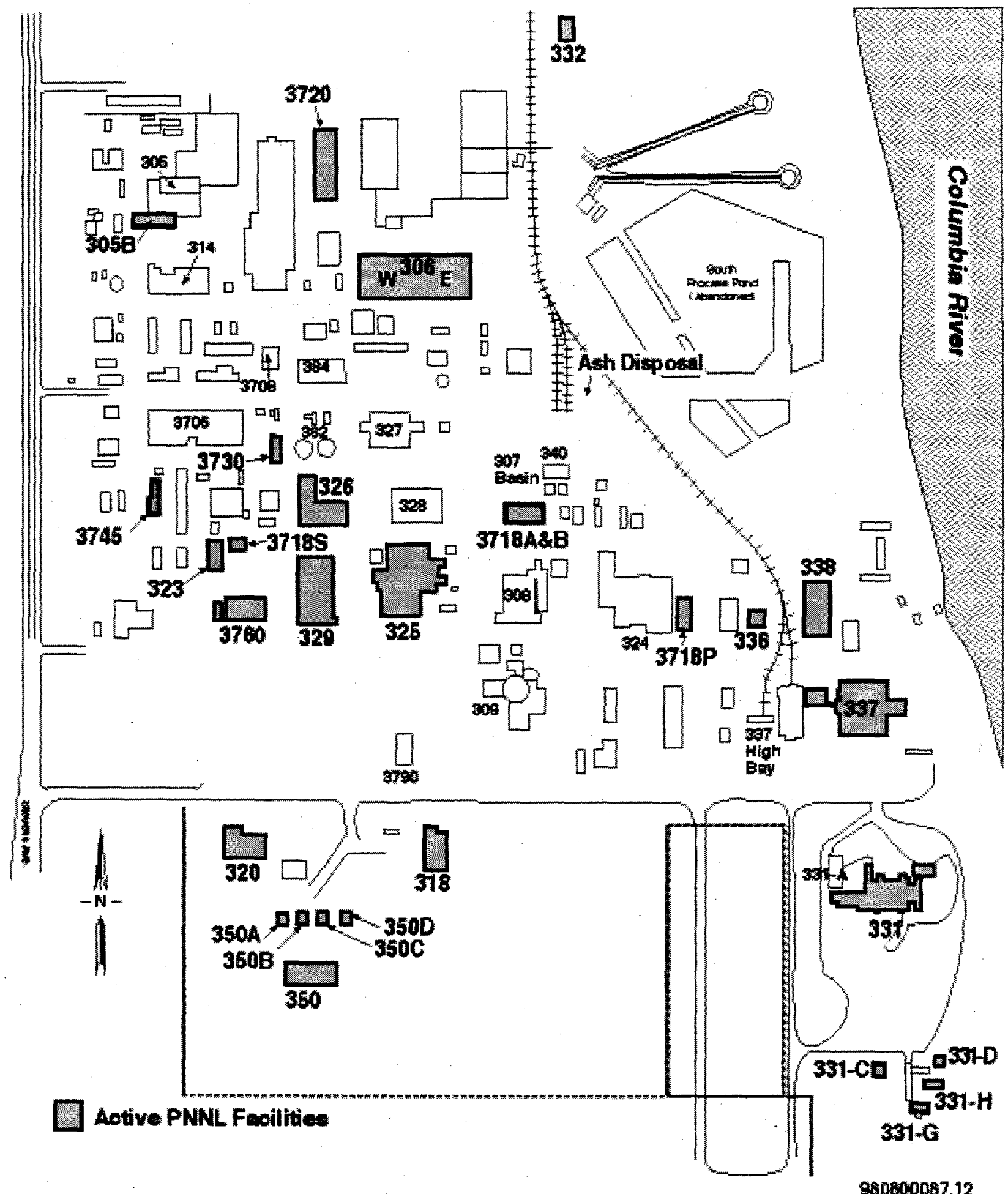

Figure 2.1 Active DOE-owned, PNNL-operated Facilities in the 300 Area of Hanford 


\section{Normal Operations}

Under normal operations, most of the BOP facilities have ventilation systems that maintain a negative pressure in the building. Air is drawn into the building, through work areas, and carried through ducts to one or more emission points. Radionuclide air emissions from projects are evaluated on a case-by-case basis to determine compliance with permitting requirements for air emissions. The need for monitoring airborne emissions of hazardous chemicals is established in the Hanford Site Air Operating Permit. Based on the current potential-to-emit, the permit does not contain general monitoring requirements for BOP facilities. However, the permit identifies monitoring requirements for specific projects and buildings Needs for future monitoring will be established by future permits issued pursuant to the applicable state and federal regulations, e.g. WAC 173-400 General Regulations for Air Pollution Sources, and WAC 173460 Controls for New Sources of Toxic Air. Pollutants.

Facilities are equipped with liquid effluent systems that transport liquid waste streams to centralized treatment facilities. Under normal operations, liquid wastes are generated, designated as regulated or non-regulated, and only discharged to sewer systems after determining that the waste meets the appropriate discharge criteria.

\section{Upset Conditions}

Upset conditions for air emissions include failure of the building ventilation system resulting in air emissions following a different pathway or inadvertent or unusual generation of airborne materials resulting in unexpected emissions. Section 3.5.2 discusses upset conditions that have been classified as off-normal or unusual occurrences. Failure of the building ventilation system (due to power outage or malfunction in the exhaust system) is the predominant type of upset.

Upset conditions for liquid effluents are similar in that a failure (break in the piping, pump malfunction) may occur, causing effluents to be spilled, or material may be inadvertently discharged to a sewer system resulting in unexpected effluents. Very few of these types of upsets have actually occurred (see Section 3.5.2). However, liquid effluent monitoring is performed as needed to respond to these events.

\subsubsection{Chemical}

Chemical storage and usage are well dispersed throughout the BOP facilities and consist of bulk materials (solvents, acids/bases), small volume chemicals, and standards used in conducting laboratory experiments. All chemicals within each facility are inventoried and tracked via an electronic database.

Of the more than a thousand different chemicals in the BOP Facilities, only a fraction have the potential for exceeding the reportable quantities (RQs) specified in EPA (1997). RQs are the amounts which, if released to the environment from a facility, require notification to the National Response Center. All chemicals, their locations, and quantities, are tracked using PNNL's Chemical Management System (CMS). Each of the BOP facilities has an FUA that provides the capabilities and limitations on chemical usage for the facility.

Many of the laboratories contain satellite accumulation areas for liquid and solid hazardous wastes. An active inventory of the waste contents is maintained. Liquid and solid wastes are disposed of in accordance with guidelines described in PNNL's Standards Based Management System (SBMS). The SBMS is available electronically on the Internet at http://sbms.pnl.gov:2080/. The SBMS elements on waste management and effluent control are PNL-MA-8, Waste Management and Environmental Compliance (PNNL 1997), and the following Subject Areas: Managing Non-radioactive Chemical Waste, Managing Liquid Effluents, and Airborne Emissions (SBMS Managing Non-radioactive Chemical Waste, Managing Liquid Effluents, and Airborne Emissions, and Airborne Emissions)

\subsubsection{Radionuclide}

Radioactive material storage and usage are dispersed throughout many BOP facilities and include a large number of isotopes. These materials are found in several forms, including solid, liquid, particulate, and gas. Some of these materials may be heated during R\&D activities producing vapors. 
A current inventory for each building is assessed yearly to determine radiological air emission monitoring. This inventory list is a combination of the following three lists:

- Part 1 - Inventory Estimates provided by staff responsible for radioactive materials, which is any radionuclide material that is not included in the Part 2 or Part 3 inventories.

- Part 2 - Composite Radioactive Material Inventory, which contains data on sealed sources that are assigned to custodians and accounted for by PNNL Health and Safety Department.

- Part 3 - Nuclear Materials Inventory, which is the inventory of special nuclear material (SNM) that is maintained in a material balance area (MBA) and assigned to an MBA custodian.

The assessment methodology is documented in Ballinger, Jette, and Sula (1995). Appendix A provides information on the types of radionuclides found in each active BOP facility.

\subsection{Identification of Effluent Pathways}

The term "point-of-discharge," as used in this section, refers to the point at which the effluent leaves PNNL control. For airborne emissions; the discharge point coincides with the point of effluent entry into the uncontrolled environment. Thus, "discharges" of airborne emissions must comply with DOE, U.S. Environmental Protection Agency (EPA), and Washington State Department of Health (WDOH) emission control and monitoring requirements.

Liquid effluents originating in all the BOP Facilities, on the other hand, remain in a controlled system at the "point-of-discharge." At these points, the responsibility for the effluent stream, including its ultimate disposition, passes from PNNL to the site operations contractors: WMHC for process sewer in the 300 Area, DynCorp for sanitary sewer in the 300 Area, the City of Richland for the 700 Area, and EMSL ${ }^{a}$. As such, these contractors are responsible for monitoring and controlling environmental discharges of liquid effluents. However, PNNL is responsible for characterizing effluents originating in its facilities and for exercising appropriate control over the discharge of these effluents. In addition, because of an industrial wastewater permit, PNNL is responsible for monitoring the process sewer discharges at EMSL that are batch discharged to the City of Richland Publicly Owned Treatment Works (POTW).

\subsubsection{Gaseous and Aerosol Emission Pathways}

As-built ventilation drawings were prepared for the following BOP facilities: $306 \mathrm{~W}, 326$, and 329 . These drawings have been identified as "essential drawings." Any facility modification that changes building flow paths 1) must receive prior concurrence of the building manager (per PNL-MA-8), and 2) requires updating of the appropriate drawing before project close-out. The PNNL SBMS ${ }^{b}$ Subject Area "Creating or Modifying Engineering Calculations, Drawings, and Specifications" (SBMS, Creating or Modifying Engineering Calculations, Drawings, and Specifications)gives the requirements for controlling facility modifications.

The FUAs contain information on ventilation-system capabilities, including control features for air emissions. The most predominant air-emission control is high-efficiency particulate air (HEPA) filtration because work with radioactive materials is the primary concern for most of the BOP facilities. Potentially radioactively contaminated airflow usually passes through a HEPA filter before exiting the building through a stack or vent.

a PNNL-operated facilities at the Fitzner/Eberhardt Arid Lands Ecology Reserve (ALE) are only storage buildings and do not produce facility effluents that require monitoring. The $622-R$ facility in the 600 area has primarily normal sanitary effluents and is connected to a nearby sanitary system. No monitoring is required for $622-R$.

b The SBMS provides staff with Laboratory-wide standards, procedures, and guidelines for the work they perform. The Laboratory develops standards, procedures, and guidelines based on an evaluation of external requirements documents, including orders, directives, and federal, state and local laws, as well as Battelle policy. 
Most of the air emission points in the BOP facilities are part of the ventilation exhaust system. However, vents may include elevator shaft vents and sewer system vents. Under normal operations, airborne emissions travel through facility ductwork to one or more emission points from the building. If airemission sampling is required, the sampling system is located downstream of control technologies and before the location at which the air is discharged to the atmosphere. However, some BOP facilities or sections of facilities are passively ventilated, and some do not have an emission point or points. Appendix A contains information on ventilation systems for the active BOP facilities.

\subsubsection{Liquid Effluent Pathways}

Liquids effluents are discharged from the BOP Facilities via liquid waste systems. In the 300 Area (except EMSL) these include the sanitary sewer system (SNS), the process sewer system (PS), and the retention process sewer system (RPS). After they exit the buildings, these systems come under the control of DynCorp for the SNS and WHMC for the PS and RPS. Figures 2.2, 2.3, and 2.4 show the general layout of liquid effluent systems in the 300 Area.

Radioactive liquid wastes generated under normal operations are collected at individual facilities and transported to the 325 Building.(RPL) where they are discharged to the Radioactive Liquid Waste System tank. The tank contents will be transferred to a tanker for transportation to the 200 Area for disposal on an as-needed basis.

Liquid effluents from the 600 area (622-A, B, C, and R) are discharged to a nearby sanitary septic system $^{a}$. Effluents from these facilities are primarily from bathrooms and sinks in 622-R, and no wastewater monitoring is required. Almost all facilities at ALE are inactive, and liquid effluents are no longer generated.

Stormwater systems are on the outside of some BOP facilities and may drain to the soil at various locations around the building. A listing of injection wells and stormwater outfalls for PNNL facilities is maintained by PNNL's Effluent Management (EM) Group. The potential for radioactive or chemical contamination to be washed into the soil with stormwater is considered low, and no monitoring is required.

\section{Sanitary Sewer}

The 300 SNS receives effluent primarily from restrooms, lunchrooms, change rooms, some cooling processes, and other water uses in which no contamination is believed to be likely. Under normal operating conditions, no regulated materials are present in the SNS effluent. The sanitary wastewater is discharged into the 300 Area SNS, operated by DynCorp under contract with DOE. The 300 Area SNS discharges to the City of Richland POTW under a contract agreement between DOE and the City.

Sanitary effluents from EMSL and 747A also discharge to the City of Richland POTW and do not require a permit. Liquid effluents from the 622 complex are primarily sanitary, and all discharge to a nearby sanitary septic system.

\section{Process Sewer}

The PS receives process wastewater from the 300 Area, such as equipment cooling water and laboratory wastewater. In all 300 BOP facilities except EMSL, the PS discharges to the 300 Area PS System, which flows to the Treated Effluent Disposal Facility (TEDF) for treatment before discharge to the Columbia River. EMSL process water is held up in effluent tanks that are sampled before discharge to the City of Richland POTW.

a Arywell servicing discharges from a 622R kitchen sink and fume hood was identified in 1998. Carboys were installed to suspend discharges to the drywell and the inactive well was added to the list of miscellaneous streams. 


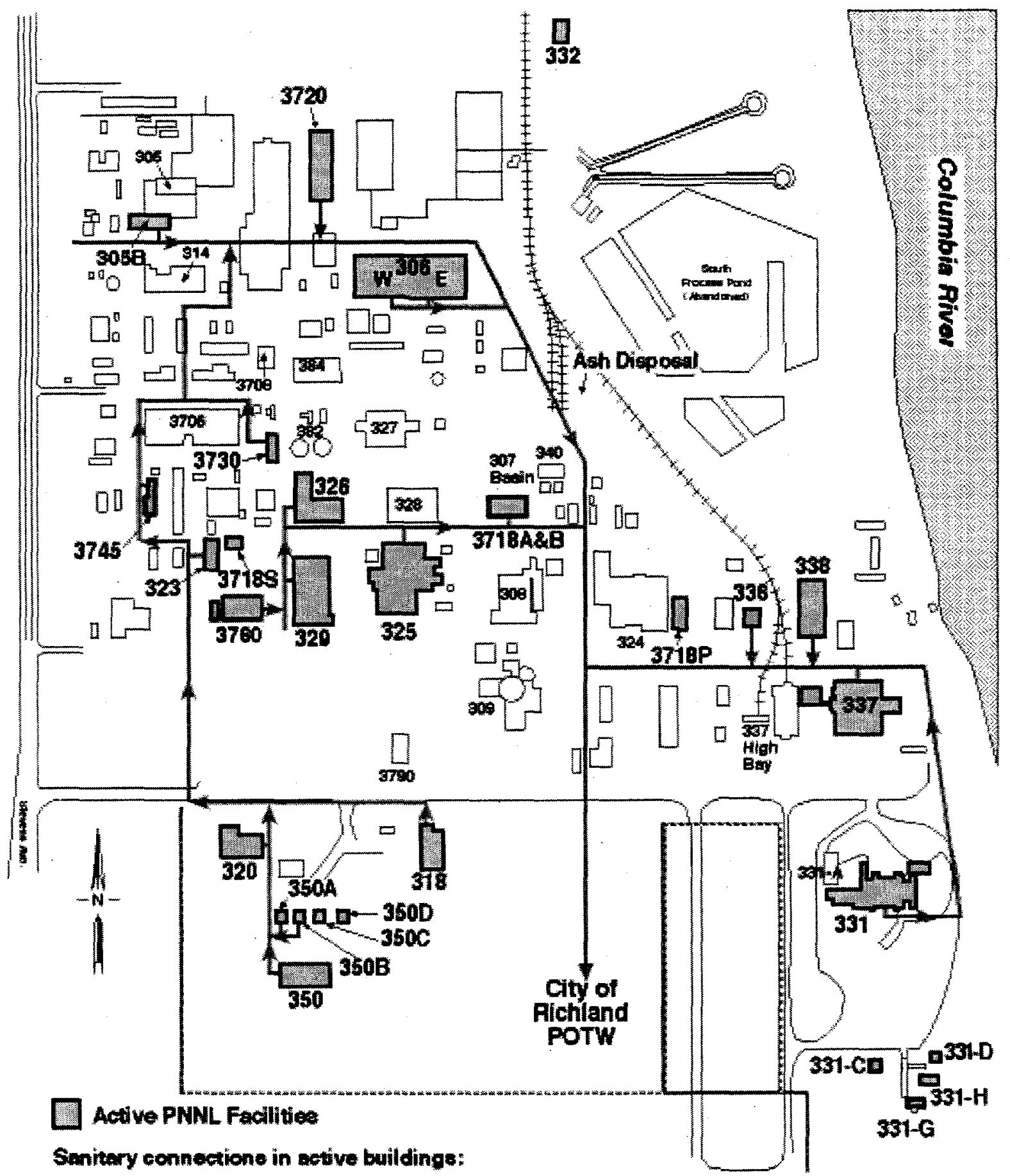

$325,3720,331,3058,308 W, 318,320,329,326,329,336,337$ 338, $350,350 \mathrm{~A}, 350 \mathrm{~B}, 3718 \mathrm{ARB}, 3730,3745,3760$

900900087.12 .

Figure 2.2 Schematic of 300 Area Sanitary Sewer 


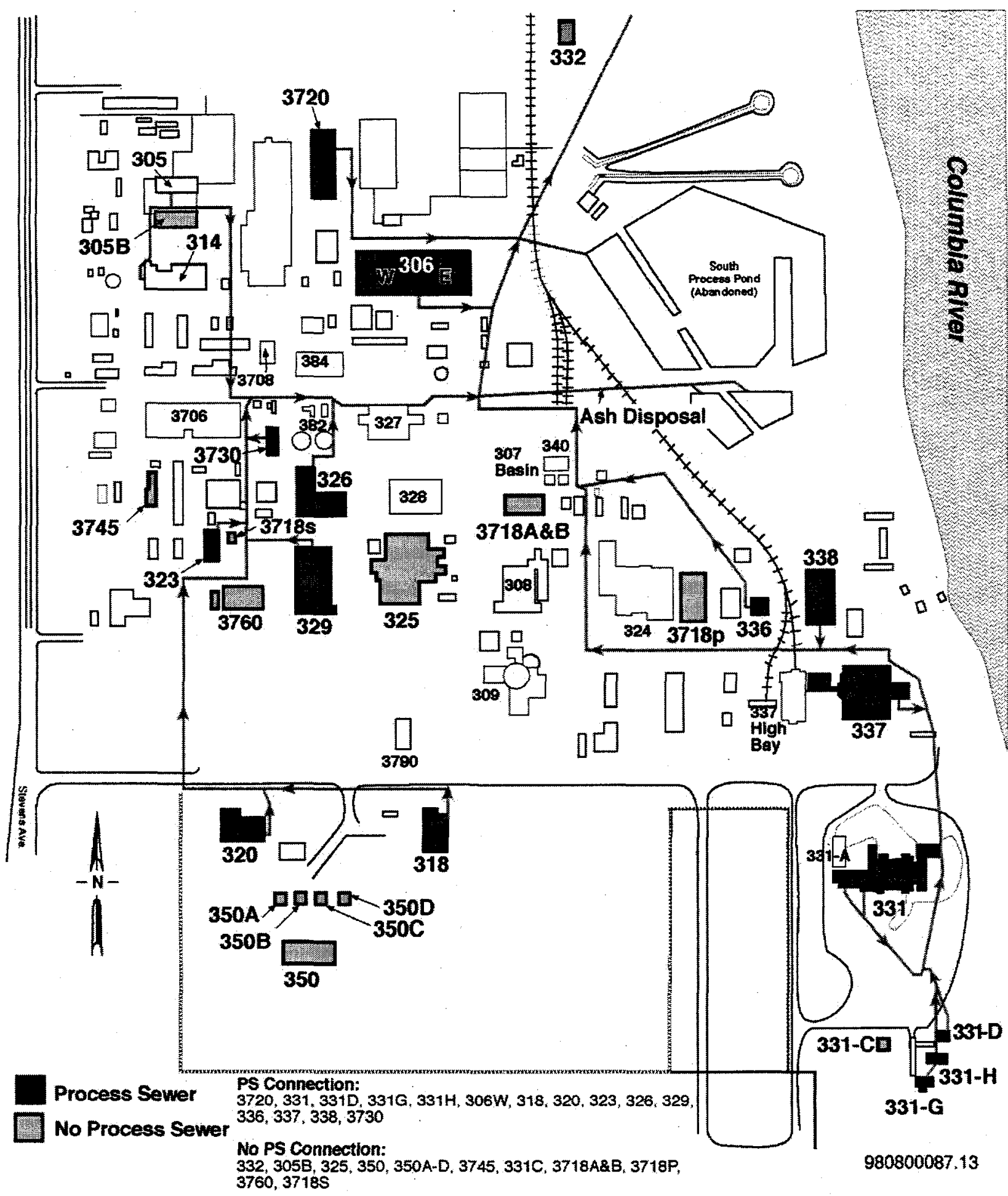

Figure 2.3 Schematic of 300 Area PS System 
The RPS receives wastewater, such as equipment cooling water, laboratory wastewater, and floor drain water, that is normally free of radioactive contamination, but has potential for such contamination in the event of a failure of an engineered barrier or administrative procedure. The only BOP Facilities that are connected to the RPS are 326 and 329 . RPS piping is routed to a diverter station inside the facility that provided automatic diversion to the RLWS before 1998 in the event of radioactive contamination being detected. The diverter station consists of a lead-shielded, gamma-radioactivity counting instrument, an automatically operated three-way valve, and associated alarms for diverting liquid flow from the RPS to RLWS if radioactivity in the waste exceeded a preset level of $5000 \mathrm{pCi} / \mathrm{L}$ of ${ }^{137} \mathrm{Cs}$ equivalent. In 1998 the diverters were modified to remove the diversion capability. The diverters will now function to provide alarm to the 340 Complex if radioactivity in the waste exceeds the preset level. The diverter station is operated and maintained by WMHC. After passing the diverter stations, the RPS liquid wastes are subsequently discharged to the 307 basins in the 340 Complex operated by WMHC. If the diverter alarms the RPS is to be diverted to a dedicated basin at the 340 Complex, if not the effluent is then screened at the 307 basins for alpha radioactivity before being discharged to the PS. Liquid effluent sampling systems for the RPS system are in place and maintained in the 326 and 329 BOP facilities. The system is sampled by PNNL on an as needed basis.

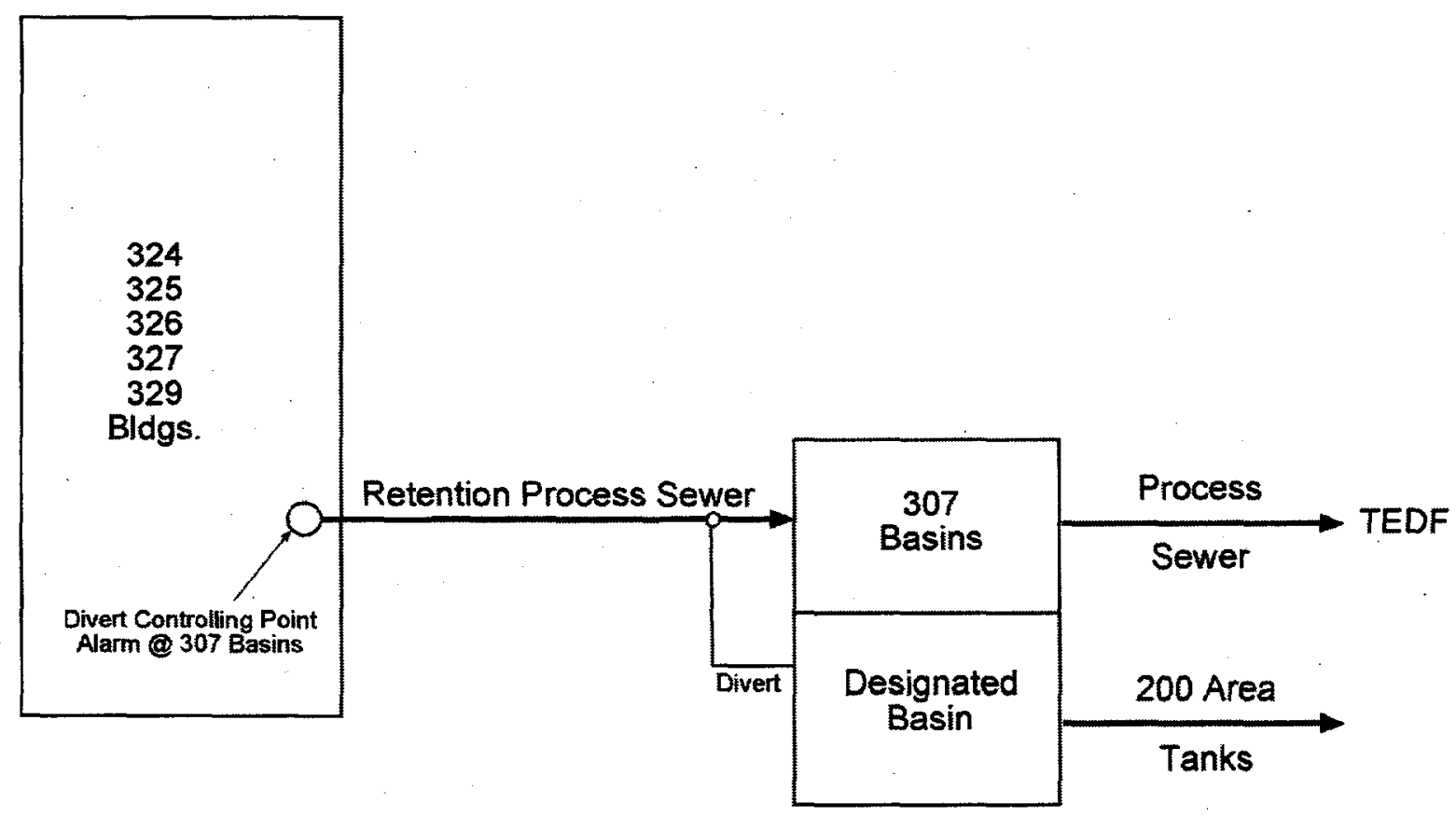

980800087.1

Figure 2.4 Schematic of 300 Area RPS System

\subsection{References}

Ballinger, M.Y., S.J. Jette, and M.J. Sula. 1995. Assessment of Unabated Facility Emission Potentials for Evaluating Airborne Radionuclide Monitoring Requirements at Pacific Northwest National Laboratory 1995, PNL-10855, Pacific Northwest National Laboratory, Richland, Washington.

DOE 1991. Environmental Regulatory Guide for Radiological Effluent Monitoring and Environmental Surveillance, DOE/EH-0173T. U.S. Department of Energy. Washington D.C.

EPA 1997. Reportable Quantities. 40 CFR 302.4. U.S. Code of Federal Regulations. U.S. Environmental Protection Agency. Washington D.C.

PNNL 1997. Waste Management and Environmental Compliance. Standards-Based Management System A-Manual PNL-MA-8 (http://sbms.pnl.gov:2080/amanuals/ma08/a008t010.htm), Pacific Northwest National Laboratory, Richland, Washington. 
SBMS, Airborne Emissions. 1998. Airborne Emissions. SBMS Subject Area

(http://sbms.pnl.gov:2080/standard/0g/0g00t010.htm), Pacific Northwest National Laboratory, Richland, Washington.

SBMS, Creating or Modifying Engineering Calculations, Drawings, and Specifications. 1997. Creating or Modifying Engineering Calculations, Drawings, and Specifications. Standards-Based Management System Subject Area (http://sbms.pnl.gov:2080/standard/91/9100t010.htm), Pacific Northwest National Laboratory, Richland, Washington.

SBMS Managing Liquid Effluents. 1998. Managing Liquid Effluents. SBMS Subject Area (http://sbms.pnl.gov:2080/standard/0q/0q00t010.htm), Pacific Northwest National Laboratory, Richland, Washington.

SBMS, Managing Nonradioactive Chemical Waste. 1998. Managing Nonradioactive Chemical Waste. Standards-Based Management System Subject Area

(http://sbms.pnl.gov:2080/standard/Of/0f00t010.htm), Pacific Northwest National Laboratory, Richland, Washington.

Washington Administrative Code 173-400, General Regulations for Air Pollution Sources

Washington Administrative Code 173-460, Controls for New Sources of Toxic Air Pollutants 
This page intentionally left blank. 


\subsection{Rationale and Design Criteria for Sampling and Monitoring}

This section discusses design criteria for the BOP Facilities effluent measurement program. Criteria are established to ensure that effluents are measured according to applicable regulations and guidance and are appropriate for current facility operations.

In this section, the terms "sampling" and "monitoring" are used to distinguish between two types of airborne or liquid effluent measurement processes:

- "Sampling" refers to collecting a representative portion of the emission over a period of time, with subsequent analysis for constituents of interest. "Sampling" is an "after-the-fact" measurement.

- "Monitoring," on the other hand, is measuring emission rates by means of a detector located in the sample stream. "Monitoring" is a "real-time" measurement.

Airborne or liquid effluents sampling is performed to demonstrate compliance with emission standards, to identify emission trends, and to provide evidence regarding the effectiveness of emission control systems (procedures and equipment). Effluent sampling may also be performed to characterize waste streams or investigate discharges of concern.

Effluent streams are monitored as a means to provide timely indication of a significant change in emission rate. Currently, monitoring is not required at any of the BOP facilities, although liquid-effluent monitoring systems are provided in some BOP facilities (see Appendix A) as a tool to investigate potential problematic discharges.

\subsection{Basis for Design Criteria}

The following regulations and guidance were considered in effluent sampling and monitoring system design and operation:

Regulations on Standards of Performance for New Stationary Sources, Appendix A: Reference Methods. Environmental Protection Agency, U.S. Code of Federal Regulations, 40 CFR 60. (EPA 1971)

National Emission Staridards for Hazardous Air Pollutants. Environmental Protection Agency, U.S. Code of Federal Regulations, 40 CFR 61 (EPA 1990).

Guide to Sampling Airborne Radioactive Materials in Nuclear Facilities. American National Standards Institute ANSI N13.1-1969 (ANSI 1969).

Specifications and Performance of Onsite Instrumentation for Continuously Monitoring Radioactivity in Effluents. American National Standards Institute ANSI N42.18 1980b (ANSI 1980).

Industrial Wastewater Permit to Environmental Molecular Sciences Laboratory (EMSL). CR-IU005. City of Richland. (City of Richland 1997).

Richland Pretreatment Program. City of Richland Ordinance No. 7-96. City of Richland. (City of Richland 1996)

Hanford Site Air Operating Permit. Washington State Department of Ecology and Washington State Department of Health. HNF-AOP-97-1 (WDOE and WDOH 1999).

Radiation Protection - Air Emissions. Washington Department of Health. Washington Administrative Code, WAC 246-247 (WAC 1994).

General Environmental Protection Program. U.S. Department of Energy. DOE 5400.1 (DOE 1988). 
Radiation Protection of the Public and the Environment. U.S. Department of Energy. DOE 5400.5 (DOE 1990).

General Design Criteria. U.S. Department of Energy. DOE 6430.1A (DOE 1987).

Environmental Regulatory Guide for Radiological Effluent Monitoring and Environmental Surveillance. U.S. Department of Energy. DOE/EH-0173T (DOE 1991).

The following are additional requirements for sampling/monitoring at the BOP Facilities as prescribed in PNNL operational and programmatic documents:

Standards-Based Management System Subject Area Airborne Emissions. Pacific Northwest National Laboratory, Richland, Washington. (SBMS, Airborne Emissions)

Standards-Based Management System Subject Area Managing Nonradioactive Chemical Waste. Pacific Northwest National Laboratory, Richland, Washington. (SBMS, Managing Nonradioactive Chemical Waste)

Standards-Based Management System Subject Area Working With Chemicals. Pacific Northwest National Laboratory, Richland, Washington. (SBMS, Working With Chemicals)

Standards-Based Management System Subject Area Managing Liquid Effluents. Pacific Northwest National Laboratory, Richland, Washington. (SBMS, Managing Liquid Effluents)

Standards-Based Management System A-Manual PNL-MA-8, Waste Management and Environmental Compliance. Pacific Northwest National Laboratory, Richland, Washington. (PNNL 1997)

Standards-Based Management System Subject Area Creating or Modifying Engineering Calculations, Drawings, and Specifications. Pacific Northwest National Laboratory, Richland, Washington. (SBMS, Creating or Modifying Engineering Calculations, Drawings, and Specifications)

\subsection{Criteria for Radiological Air Emission Sampling \& Monitoring}

Airborne radionuclide emission points at PNNL are classified as either "major" or "minor." These two categories are defined as follows:

Major emission points are those where radionuclide emissions could cause an offsite emission dose $(O E D)^{a}$ of $0.1 \mathrm{mrem} / \mathrm{yr}$ if emission controls were not applied. Major emission points are sampled according to requirements in Subpart H of EPA (1990).

Minor emission points are those that potentially could release radionuclides, but not at the levels of a "major" point.

All of the BOP facilities are either considered minor emission points or do not have a potential for releasing radionuclides.

a The annual OED is the maximum committed effective dose equivalent that could be expected to be received by an offsite individual from facility airborne radionuclide emissions if the facility was operated without any HEPA filtration or other emission controls. The method for calculating the OED consists of identifying the radionuclide inventory potentially available for release, multiplying this by a fractional release value, and multiplying this product times an emission dose factor calculated by the EPA Clean Air Act compliance code, CAP-88. Ballinger et al. (1995) provides additional discussion of this assessment method. 
Continuous emission monitoring is required for any emission system where

- a potential of greater than once per year exists for exceeding $20 \%$ of the OED standard of 10 mrem/yr (credit may be taken for emission-control equipment, such as HEPA filters) per DOE (1991)

- continuous emission monitoring is specified by a SAR or operational safety requirement.

None of the BOP facilities meet the above criteria and thus none are required to have continuous emission monitoring.

\subsubsection{Sampling System Performance Criteria}

Sampling at each minor emission point should be capable of detecting an annual radionuclide release quantity resulting in an OED of $0.1 \mathrm{mrem} / \mathrm{yr}$ (DOE 1991).

All radionuclides anticipated to contribute greater than $10 \%$ of the potential to emit (PTE) from the sampled emission point shall be accounted for, either by direct analysis or by inference from an indicator measurement (EPA 1991).

Biases in emission measurements, arising from the sample collection and analysis process, shall be minimized through the judicious application of design and operation practices according to American National Standards Institute (ANSI) (1969) and DOE (1991).

\subsubsection{Sampling System Design Criteria}

Sample extraction location criteria are provided in EPA (1971) Method 1 in Appendix A. Method 1 states that

Sampling or velocity measurements are to be performed at a site located at least eight stack or duct diameters downstream and two diameters upstream from any flow disturbance such as a bend, expansion, or contraction in the stack, or from a visible flame.

However, the method also states that

... if necessary, an alternative location may be selected, at a position at least two stack or duct diameters downstream and 0.5 diameters upstream from any flow disturbance.

For minor stack sampling, this criterion is desired, but not required.

Air emission samplers should be designed to maximize the sensitivity of the sample, considering the capacity of the collection media, radioactive decay, and sample-analysis costs. Representative samples shall be withdrawn on a continuous basis at the sampling site following the guidance in ANSI (1969), Appendix A, Section A3.2. ANSI (1969) recommends that each withdrawal point within a cylindrical stack be centered in an annular area of size equal to the cross sectional area divided by the number of probes. Withdrawal points may be on a single traverse or spaced to obtain samples from the total cross section. Additional design criteria for particulate and gaseous radionuclides are specified by ANSI (1969) and DOE (1991).

\subsubsection{Criteria for Sampling System Operation}

PNNL's Effluent Management Group maintains sampling system configuration drawings for all emission point radionuclide air sampling systems. This includes calculations of sampling system efficiencies particle sizes of 1 micron and 10 microns. A 1 micron particle size is assumed under normal operating conditions because most radionuclide air emissions are HEPA filtered.

Sampling-system operating criteria are based on regulations and guidance documents listed in Section 3.1.

Sampling is performed to verify minor stack status during a calendar year for BOP facilities with a potential to emit airborne radioactive material. The frequency of collecting samples is based on a graded 
approach considering the PTE, current and expected activities, and past practices in the facility. All of the BOP facilities are either considered minor for radioactive air emission sampling or have no potential for radioactive air emissions. Continuous sampling is conducted at the minor emission points that meet the following criteria:

- assessment of potential emissions indicate that the point is near the borderline of 'minor.' In dose terms, these are emission points for which the potential unmitigated annual offsite dose exceeds $0.01 \mathrm{mrem} / \mathrm{yr}$.

- radionuclide emissions occur and are highly variable over time such that periodic release measurements do not provide an adequate means for confirming that annual emissions are low.

- continuous sampling is deemed necessary after considering the following factors: radionuclide inventory, release history, emission controls, current activities.

Minor emission points that do not meet the above criteria are sampled either quarterly or annually, depending on their emission potential. Because DOE requires an annual emission report, minor emission points are sampled a minimum of once per year, although hand calculations may be used to estimate emissions for some facilities. The period of sample collection is based primarily on the capacity of the collection media. A current radionuclide air sampling schedule for BOP facilities is maintained within the Gaseous Effluent Database (GED).

Samples are analyzed in the Laboratory according to procedures required by Appendix B, Method 114 "Test Methods for Measuring Radionuclide Emissions from Stationary Sources" in 40 CFR 61. Radioanalytical laboratories analyze samples according to prescribed statements of work. Work statements specify analytical performance requirements, including minimum detectable activity (MDA), turnaround time, reporting requirements, quality control (QC) requirements, and sample handling.

Sampling performance criteria in Section 3.2.1 specify an emission detection level of 0.01-mrem/yr OED. The analytical MDA required to meet this criterion depends on a combination of factors, including sample size, stack flow rate, collection period, radionuclide half-life, and radionuclide emission dose factor.

Historically, laboratory analysis of particulate emission samples consisted of total activity (total alpha, total beta) measurements. Total-activity measurements were performed because

- emissions have historically been very low

- potentially significant constituents of the emission stream were known

- the gross activity measurement is nondestructive; the sample could be measured for specific radionuclides if gross activity measurements show a potentially significant release quantity.

When gross activity measurements were used for assessing offsite dose, dose factors for the most restrictive radionuclide were applied.

Exhaust stream flow rates at sampling locations are measured using EPA Method 2 (EPA 1971). Flowrate measurements are performed annually or when modifications are made or flows change more than $\pm 10 \%$.

\subsection{Historical Sampling Data for Effluent Streams}

When required, the effluent streams from the BOP facilities have been sampled over the history of operations. Information from historical sampling and monitoring is provided here (additional detail in Appendix A) to aid in providing a basis for future sampling needs. Historical sampling has been performed for some BOP facilities to measure radioactive air emissions and to characterize liquid effluents. No historic data (before 1998) exists for air-chemical emissions. The following section provides a description of historic sampling data under normal operating conditions for air- and liquid-effluent streams. Estimates of the types of releases and release pathways experienced during plant operations under upset conditions are given in Section 3.3.2.

\subsubsection{Normal Conditions}

Some of the air- and liquid-effluent streams have been sampled since some of the BOP facilities started operations. The types and locations of sampling and analytical methods under normal operations are 
described in this section. Discussion is generally limited to the past 7 years (1991 to 1998) because this time period is the most relevant to future operations and monitoring needs.

\subsubsection{Historical Radioactive Air Effluent Sampling}

Effluent air from the BOP Facility emission points has been sampled and monitored downstream of the final HEPA filters for radioactive particles and tritium (326 only). Sampling for particulate gross alpha and beta has been provided by record sampler for facilities with a potential to emit radionuclides. Data from 1991 to 1997 are provided in Table 3.1. In 1996, PNNL implemented a graded approach to sampling, depending on a number of facility factors. Continuous sampling continued to be conducted at all major emission points and for minor emission points that met the following criteria:

- assessment of potential emissions indicate that the point is near the borderline of 'minor.' In dose terms, these are emission points for which the potential unmitigated annual offsite dose exceeds $0.01 \mathrm{mrem} / \mathrm{yr}$.

- radionuclide emissions occur and are highly variable over time such that periodic release measurements do not provide an adequate means for confirming that annual emissions are low.

- continuous sampling is deemed necessary after considering the following factors: radionuclide inventory, release history, emission controls, and current activities.

BOP facilities with potential radiological air emissions that were minor, but did not meet the above criteria, were sampled on a less frequent basis, either quarterly or annually, depending on their emission potential.

Table 3.1 Radionuclide Air Emissions from BOP Facilities

\begin{tabular}{|c|c|c|c|c|c|c|c|c|}
\hline Building & Measure & 1991 & 1992 & 1993 & 1994 & 1995 & 1996 & 1997 \\
\hline $303-C$ & $\begin{array}{l}\text { Total Alpha } \\
\text { Total Beta }\end{array}$ & $\begin{array}{l}1.9 \mathrm{E}-8 \\
4.5 \mathrm{E}-7\end{array}$ & $\begin{array}{l}4.6 \mathrm{E}-8 \\
1.6 \mathrm{E}-7\end{array}$ & $\begin{array}{l}1.9 \mathrm{E}-8 \\
1.3 \mathrm{E}-7\end{array}$ & $\begin{array}{l}1.4 \mathrm{E}-8 \\
6.8 \mathrm{E}-8\end{array}$ & $\begin{array}{l}6.1 \mathrm{E}-9 \\
7.3 \mathrm{E}-8\end{array}$ & $\begin{array}{l}6.2 \mathrm{E}-9 \\
7.6 \mathrm{E}-8\end{array}$ & Inactive \\
\hline $305-B$ & $\begin{array}{l}\text { Total Alpha } \\
\text { Total Beta }\end{array}$ & & & & & & $\begin{array}{l}1.7 \mathrm{E}-10 \\
3.0 \mathrm{E}-9\end{array}$ & $\begin{array}{l}N D^{a} \\
4.4 E-9\end{array}$ \\
\hline $306-W$ & $\begin{array}{l}\text { Total Alpha } \\
\text { Total Beta }\end{array}$ & $\begin{array}{l}9.2 \mathrm{E}-7 \\
4.9 \mathrm{E}-5\end{array}$ & $\begin{array}{l}1.6 \mathrm{E}-7 \\
5.9 \mathrm{E}-6\end{array}$ & $\begin{array}{l}6.6 \mathrm{E}-7 \\
2.6 \mathrm{E}-6\end{array}$ & $\begin{array}{l}2.9 \mathrm{E}-7 \\
1.7 \mathrm{E}-6\end{array}$ & $\begin{array}{l}2.2 \mathrm{E}-7 \\
2.7 \mathrm{E}-6\end{array}$ & $\begin{array}{l}2.7 \mathrm{E}-7 \\
1.7 \mathrm{E}-6\end{array}$ & $\begin{array}{l}5.0 \mathrm{E}-8 \\
5.0 \mathrm{E}-7\end{array}$ \\
\hline 314 & $\begin{array}{l}\text { Total Alpha } \\
\text { Total Beta }\end{array}$ & $\begin{array}{l}6.0 \mathrm{E}-8 \\
2.1 \mathrm{E}-6\end{array}$ & $\begin{array}{l}3.0 \mathrm{E}-8 \\
4.2 \mathrm{E}-7\end{array}$ & $\begin{array}{l}3.9 \mathrm{E}-8 \\
7.1 \mathrm{E}-7\end{array}$ & $\begin{array}{l}1.9 \mathrm{E}-8 \\
1.2 \mathrm{E}-7\end{array}$ & $\begin{array}{l}1.2 \mathrm{E}-8 \\
1.2 \mathrm{E}-7\end{array}$ & $\begin{array}{l}2.2 E-8 \\
9.3 E-8\end{array}$ & Inactive \\
\hline 318 & $\begin{array}{l}\text { Total Alpha } \\
\text { Total Beta }\end{array}$ & $\begin{array}{l}3.0 \mathrm{E}-8 \\
2.0 \mathrm{E}-6\end{array}$ & $\begin{array}{l}5.7 \mathrm{E}-8 \\
8.2 \mathrm{E}-7\end{array}$ & $\begin{array}{l}7.5 \mathrm{E}-8 \\
3.0 \mathrm{E}-7\end{array}$ & $\begin{array}{l}1.2 \mathrm{E}-8 \\
4.8 \mathrm{E}-8\end{array}$ & $\begin{array}{l}3.5 \mathrm{E}-8 \\
4.0 \mathrm{E}-7\end{array}$ & $\begin{array}{l}1.1 \mathrm{E}-7 \\
1.5 \mathrm{E}-6\end{array}$ & $\begin{array}{l}7.5 \mathrm{E}-8 \\
1.5 \mathrm{E}-6\end{array}$ \\
\hline 320 & $\begin{array}{l}\text { Total Alpha } \\
\text { Total Beta }\end{array}$ & $\begin{array}{l}4.0 \mathrm{E}-7 \\
2.4 \mathrm{E}-5\end{array}$ & $\begin{array}{l}7.1 \mathrm{E}-7 \\
5.3 \mathrm{E}-6\end{array}$ & $\begin{array}{l}6.9 \mathrm{E}-7 \\
4.8 \mathrm{E}-6\end{array}$ & $\begin{array}{l}3.5 \mathrm{E}-7 \\
1.8 \mathrm{E}-6\end{array}$ & $\begin{array}{l}1.9 E-7 \\
2.3 E-6\end{array}$ & $\begin{array}{l}2.4 \mathrm{E}-7 \\
2.9 \mathrm{E}-6\end{array}$ & $\begin{array}{l}8.8 E-8 \\
1.3 E-6\end{array}$ \\
\hline 323 & $\begin{array}{l}\text { Total Alpha } \\
\text { Total Beta }\end{array}$ & $\begin{array}{l}6.8 \mathrm{E}-8 \\
2.1 \mathrm{E}-6\end{array}$ & $\begin{array}{l}7.8 \mathrm{E}-8 \\
1.1 \mathrm{E}-6\end{array}$ & $\begin{array}{l}1.1 \mathrm{E}-7 \\
3.5 \mathrm{E}-7\end{array}$ & $\begin{array}{l}2.7 \mathrm{E}-8 \\
1.6 \mathrm{E}-7\end{array}$ & $\begin{array}{l}2.0 \mathrm{E}-8 \\
1.1 \mathrm{E}-7\end{array}$ & $\begin{array}{l}8.9 \mathrm{E}-9 \\
6.1 \mathrm{E}-8\end{array}$ & $\begin{array}{l}1.6 \mathrm{E}-8 \\
1.3 \mathrm{E}-7\end{array}$ \\
\hline 326 & $\begin{array}{l}\text { Total Alpha } \\
\text { Total Beta } \\
\text { Tritium }\end{array}$ & $\begin{array}{l}7.8 \mathrm{E}-7 \\
3.1 \mathrm{E}-5 \\
2.4 \mathrm{E}-1\end{array}$ & $\begin{array}{l}1.1 \mathrm{E}-6 \\
2.1 \mathrm{E}-5 \\
4.6 \mathrm{E}-1\end{array}$ & $\begin{array}{l}2.4 \mathrm{E}-6 \\
2.1 \mathrm{E}-5\end{array}$ & $\begin{array}{l}1.2 \mathrm{E}-6 \\
5.2 \mathrm{E}-6 \\
5.0 \mathrm{E}-3\end{array}$ & $\begin{array}{l}5.9 \mathrm{E}-7 \\
6.7 \mathrm{E}-6\end{array}$ & $\begin{array}{l}7.1 \mathrm{E}-7 \\
7.3 \mathrm{E}-6\end{array}$ & $\begin{array}{l}5.2 \mathrm{E}-7 \\
7.6 \mathrm{E}-6\end{array}$ \\
\hline 329 & $\begin{array}{l}\text { Total Alpha } \\
\text { Total Beta }\end{array}$ & $\begin{array}{l}7.0 \mathrm{E}-7 \\
2.3 \mathrm{E}-5\end{array}$ & $\begin{array}{l}1.2 \mathrm{E}-7 \\
5.6 \mathrm{E}-6\end{array}$ & $\begin{array}{l}8.7 \mathrm{E}-7 \\
5.2 \mathrm{E}-6\end{array}$ & $\begin{array}{l}1.6 \mathrm{E}-7 \\
8.4 \mathrm{E}-7\end{array}$ & $\begin{array}{l}4.6 \mathrm{E}-8 \\
4.7 \mathrm{E}-7\end{array}$ & $\begin{array}{l}\text { ND } \\
\text { ND }\end{array}$ & $\begin{array}{l}\text { ND } \\
1.2 \mathrm{E}-7\end{array}$ \\
\hline 3708 & $\begin{array}{l}\text { Total Alpha } \\
\text { Total Beta }\end{array}$ & $\begin{array}{l}1.0 \mathrm{E}-7 \\
3.6 \mathrm{E}-6\end{array}$ & $\begin{array}{l}\text { ND } \\
8.0 E-7\end{array}$ & $\begin{array}{l}8.0 \mathrm{E}-8 \\
4.9 \mathrm{E}-7\end{array}$ & $\begin{array}{l}3.0 \mathrm{E}-8 \\
1.2 \mathrm{E}-7\end{array}$ & $\begin{array}{l}1.6 \mathrm{E}-8 \\
1.1 \mathrm{E}-7\end{array}$ & $\begin{array}{l}2.0 \mathrm{E}-8 \\
9.2 \mathrm{E}-8\end{array}$ & $\begin{array}{l}\text { ND } \\
8.7 E-8\end{array}$ \\
\hline 3730 & $\begin{array}{l}\text { Total Alpha } \\
\text { Total Beta }\end{array}$ & $\begin{array}{l}1.6 \mathrm{E}-9 \\
1.4 \mathrm{E}-7\end{array}$ & $\begin{array}{l}\text { ND } \\
3.4 E-8\end{array}$ & $\begin{array}{l}3.1 \mathrm{E}-9 \\
4.9 \mathrm{E}-8\end{array}$ & $\begin{array}{l}1.5 \mathrm{E}-9 \\
6.2 \mathrm{E}-9\end{array}$ & $\begin{array}{l}3.0 \mathrm{E}-10 \\
7.7 \mathrm{E}-9\end{array}$ & $\begin{array}{l}7.4 \mathrm{E}-10 \\
7.6 \mathrm{E}-9\end{array}$ & $\begin{array}{l}5.7 \mathrm{E}-10 \\
4.2 \mathrm{E}-9\end{array}$ \\
\hline 3745 & $\begin{array}{l}\text { Total Alpha } \\
\text { Total Beta }\end{array}$ & $\begin{array}{l}5.8 \mathrm{E}-9 \\
1.8 \mathrm{E}-7\end{array}$ & $\begin{array}{l}9.5 \mathrm{E}-9 \\
1.1 \mathrm{E}-7\end{array}$ & $\begin{array}{l}1.2 \mathrm{E}-8 \\
4.3 \mathrm{E}-8\end{array}$ & $\begin{array}{l}4.8 E-9 \\
2.6 E-8\end{array}$ & $\begin{array}{l}2.5 \mathrm{E}-9 \\
2.3 \mathrm{E}-8\end{array}$ & $\begin{array}{l}1.0 \mathrm{E}-8 \\
2.9 \mathrm{E}-8\end{array}$ & $\begin{array}{l}2.6 \mathrm{E}-9 \\
3.5 \mathrm{E}-8\end{array}$ \\
\hline $3746-A$ & $\begin{array}{l}\text { Total Alpha } \\
\text { Total Beta }\end{array}$ & $\begin{array}{l}3.9 \mathrm{E}-8 \\
1.9 \mathrm{E}-6\end{array}$ & $\begin{array}{l}\text { ND } \\
5.1 \mathrm{E}-7\end{array}$ & $\begin{array}{l}4.4 \mathrm{E}-8 \\
2.2 \mathrm{E}-7\end{array}$ & $\begin{array}{l}8.9 E-9 \\
4.2 E-8\end{array}$ & $\begin{array}{l}\text { ND } \\
3.5 \mathrm{E}-8\end{array}$ & $\begin{array}{l}\text { ND } \\
2.3 E-8\end{array}$ & Inactive \\
\hline $6652-\mathrm{H}$ & $\begin{array}{l}\text { Total Alpha } \\
\text { Total Beta }\end{array}$ & & $\begin{array}{l}2.9 \mathrm{E}-8 \\
5.0 \mathrm{E}-7\end{array}$ & $\begin{array}{l}4.0 \mathrm{E}-8 \\
1.8 \mathrm{E}-7\end{array}$ & $\begin{array}{l}1.5 \mathrm{E}-8 \\
6.6 \mathrm{E}-8\end{array}$ & $\begin{array}{l}2.8 \mathrm{E}-9 \\
6.1 \mathrm{E}-8\end{array}$ & $\begin{array}{l}\text { ND } \\
9.0 \mathrm{E}-9\end{array}$ & Inactive \\
\hline
\end{tabular}

${ }^{a} \mathrm{ND}=$ Nondetectable 


\subsubsection{Historical Liquid Effluent Monitoring}

Liquid waste streams in the BOP facilities have been served by the systems as described in Section 2.2.2. Most of the BOP facilities are in the 300 Area. Liquid effluent streams from PNNL facilities in other areas have not been monitored and are not currently required to be monitored. Therefore, this section focuses on the 300 Area liquid waste systems.

Table 3.2 summarizes the type of historical monitoring/sampling each liquid waste system has had. As noted in the table, historically, 300 Area sanitary liquid waste was sampled at the SNS system just before the waste entered the SNS septic tanks. Before 1997, sanitary wastes were discharged to a 300 Area septic tank/trench system. In 1997, the 300 Area SNS was connected to the City of Richland POTW. A brief description of the sampling and analysis program before connection to the City of Richland POTW is given in the Westinghouse Hanford Company Effluent Report for 300,400 , and 1100 Area Operations (McCarthy 1990). Because this sampling program is not specific to the BOP facilities, its historical data is not reported here.

Historically, the 300 Area PS was discharged to trenches. Samples of the composite liquid waste from all the 300 Area PS lines were taken before the liquid was discharged to the 300 Area process trenches (McCarthy 1990). These sampling data are not specific to PNNL BOP facilities and thus are not included in this report. However, in December 1994, a treatment facility, the 300 Area TEDF, was brought into operation to replace the trenches. Around that time, PNNL conducted a sampling campaign to characterize the waste streams from the primary PNNL R\&D facilities. Results of this campaign are documented in Thompson et al. (1997). Sampling and analysis for radioactive and non-radioactive constituents occurred at the following BOP waste streams as a result of the campaign: 306-W PS, 320 PS, 326 PS, and RPS. A summary of the data is provided in Appendix A.

Only two BOP facilities have RPS systems: 326 and 329 . The RPS from both buildings is routed to a diversion station in 326 equipped with a radioactivity monitor that measured gamma activity and an automatically operated three-way valve that diverted flow to the RLWS if radioactivity above a preset level was detected in the waste stream. Diverter alarms were annunciated in various locations in each facility when diversion occurred, and a sample was taken automatically. Data from the monitor were not recorded. As shown in Table 3.3, diversion of these RPS streams rarely occurred; only three diversions took place from 1991 to mid-1998.

Normally, the RPS passed through the diverter stations and subsequently (after 307 Basins) into the 300 Area PS lines. As previously described, this stream was discharged to trenches before December. 1994 and to the 300 Area TEDF after that date.

The RLWS, deactivated in 1998, served RPS diverted liquid-waste streams. Waste diverted to the RLWS lines discharged to the 340 Building. The composite water in the holding tanks at the 340 Building was sampled before being transferred to the 200 Area by rail car. Because the RLWS stream was not released to the environment, the sampling program is not pertinent to the FEMP.

Table 3.2 Summary of Historical Liquid Monitoring/Sampling

\begin{tabular}{|c|c|}
\hline System & Notes \\
\hline SNS & $\begin{array}{l}\text { No sampling or monitoring at BOP Facilities. Sampled as composite with other } \\
300 \text { Area SNS before } 1997 \text { and sampled as required by contract with City of } \\
\text { Richland POTW after } 1997 \text { hook-up. Currently required sampling is performed } \\
\text { by the } 300 \text { Area infrastructure contractor. }\end{array}$ \\
\hline PS & $\begin{array}{l}\text { Sampling of } 306-W \text { PS, } 320 \text { PS, and } 326 \text { PS conducted as part of PNNL's } \\
1994 \text { and } 1995 \text { sampling campaign to characterize liquid wastes for TEDF. }\end{array}$ \\
\hline RPS & $\begin{array}{l}\text { RPS for } 326 \text { and } 329 \text { Facilities monitored at diverter station in } 326 \text { Facility. } \\
\text { Sampling at } 326 \text { RPS was conducted as part of PNNL's } 1994 \text { and } 1995 \\
\text { sampling campaign. Sampled as composite with other } 300 \text { Area RPS } \\
\text { wastewater at the } 307 \text { Basins. }\end{array}$ \\
\hline RLWS & Sampled at 340 Building before transport to the 200 Area tanks. \\
\hline EMSL & $\begin{array}{l}\text { Process wastewater sampled at effluent tank pit before discharge to City of } \\
\text { Richland POTW. }\end{array}$ \\
\hline
\end{tabular}


EMSL started operations in 1997, and sampling was initiated at that time. A summary of the compliance liquid effluent sampling data from the first year of operation is provided in Appendix $A$.

\subsubsection{Upset Conditions}

The nature of upset conditions potentially affecting the environment around or effluent sampling systems in the BOP Facilities since 1991 are shown in Table 3.3. This table summarizes the events noted as offnormal or unusual occurrences. The types of events shown in the table could be expected to occur during future operations and are considered in effluent monitoring planning.

Table 3.3 Off-Normal and Unusual Occurrences in the BOP Facilities

\begin{tabular}{|l|c|}
\hline \multicolumn{1}{|c|}{ Type of Event } & $\begin{array}{c}\text { Number of } \\
\text { Occurrences }\end{array}$ \\
\hline $\begin{array}{l}\text { Release of hazardous material/radioactive contamination to the ground or } \\
\text { contaminated equipment found outside BOP facilities }\end{array}$ & 20 \\
\hline Power outages affecting single or multiple facilities & 18 \\
\hline Spills of fuel or antifreeze to the ground & 9 \\
\hline Disruption/failure of facility exhaust flow & 8 \\
\hline Spill of hazardous material inside facility (primarily Hg spills) & 4 \\
\hline Release of hazardous material/radioactive contamination to sinks or hoods & 3 \\
\hline $\begin{array}{l}\text { Diversion of the Retention Process Sewer to the Radioactive Liquid Waste } \\
\text { System }\end{array}$ & 3 \\
\hline Failure of vacuum pump supporting facility air emission sampler & 2 \\
\hline
\end{tabular}

The greatest number of environmental events listed above occurred outside the facilities and outside the range of facility effluent monitoring equipment. However, they indicate the potential for spills and contamination inside the facility, many of which would not be considered an off-normal occurrence (ONO) or unusual occurrence (UO) because it could be cleaned up with no adverse effects. As shown in Table 3.3, spills of mercury within facilities and spills of hazardous or radioactive materials to sinks or hoods where they could be released to the environment are the types of events classified as an ONO or UO. For contamination found in sinks or traps, liquid effluent sampling is performed at the time the contamination is found to quantify the release, determine potential effects, or evaluate the impact on future effluents. At EMSL, spills may trigger isolation of the receiving tank and special sampling.

Wastes that are diverted from the RPS to the RLWS are not released to the environment. However, when these occur, investigative action is taken by PNNL to determine the cause of the diversion. In some cases, samples of the diverted stream may be taken by PNNL or by the RLWS operator to aid in the investigation.

Disruptions to the facility primary power, exhaust flow, or air emission sampling systems may interrupt air emission sampling periods. For BOP facilities, the purpose of radioactive air emission sampling is to confirm the low air emissions. Thus, interruptions are not considered critical and the sampling period can be adjusted or a discrepancy report completed to identify and correct for the effect on the measurements taken. Sampling for air chemical emissions or liquid effluents is periodic and loss of power or sampling equipment malfunctions is also not considered critical. Similar adjustments can be made in the measurement data.

\subsection{Sampling System Descriptions}

\subsubsection{Radiological Air Sampling System}

Airborne radionuclide emissions are sampled at BOP emission points as identified in the sampling plan maintained in the Gaseous Emissions Database (GED). Ventilation flow rates from these emission points are measured yearly at a minimum and range from 300 to $60,000 \mathrm{cfm}$.

To support the development of a stack emission measurement program for the BOP Facilities, knowledge of the types and quantities of radionuclides potentially present in the ventilation exhaust is necessary. An index of emission potential is used by PNNL so that the relative significance of different radionuclides and 
different emission points can be compared. The index, expressed in terms of a projected potential dose equivalent to a maximum offsite receptor, is based on emission assessment methods in Appendix $D$ of EPA (1971). It is assumed that no engineered emission controls (e.g., HEPA filters) are provided in the ventilation system and that without such controls, the potential for radionuclide emissions is related to the quantity and physical form of radioactive material in the facility. This assessment method is described in Ballinger et al. (1995).

Radionuclide air sampling systems in BOP Facilities range from multi-nozzle probes to single tubes. The samplers generally consist of a probe that projects into the stack or vent, a sample transport line that extends from the probe assembly to where a sample collection filter is located.

Stack particulate emission samples are withdrawn from the stack and through the sampling system by means of the building vacuum system or portable pump. The sampling rate is controlled using a control valve located downstream of the particulate sampling filter. Sample flow is measured by a rotameter upstream of the control valve. Figure 3.1 is a schematic of a typical BOP air sampling system. Stack velocities are measured on an annual frequency using Method 2 in EPA (1971) or when modifications are made or flows change more than $\pm 10 \%$.

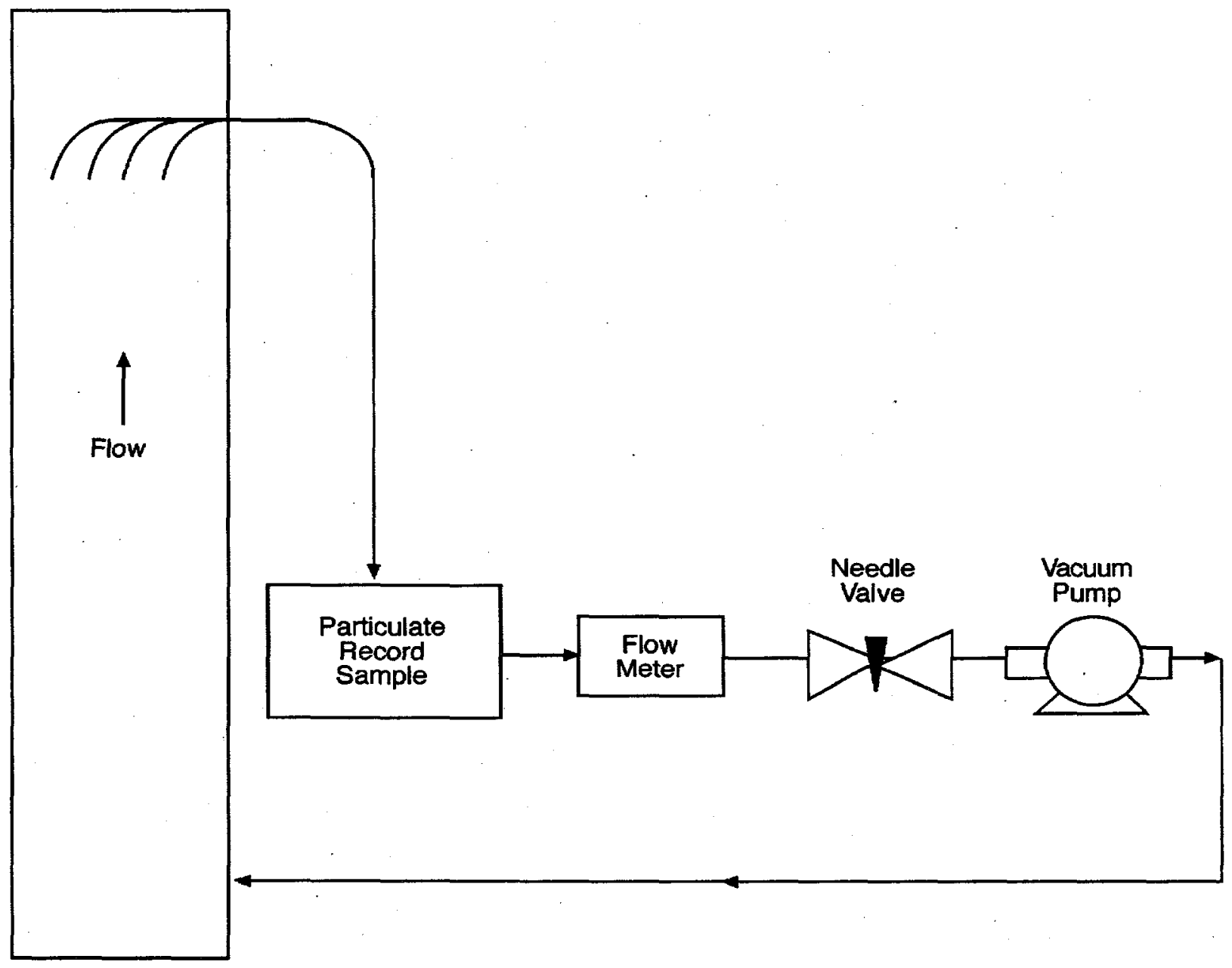

Figure 3.1 Schematic of Typical Air Sampling System

980800087.15 
Transport efficiency of the sample through the stack particulate sampling system has been calculated using the deposition (DEPO) Code and assuming a 1 micron activity median aerodynamic diameters (AMAD) aerosol at nominal sampler and stack flow rates ${ }^{(a)}$

Airborne particles are collected on a 47-mm diameter membrane filter (Gellman Versapor V-3000TN). The $V-3000 T N$ has an estimated retention efficiency for 0.3 -micron particles of greater than $91 \%$ at face velocities of $180 \mathrm{fpm}$.

The sample collection filter is used for a 2-week continuous sampling period. The sample filter may be replaced more frequently depending on filter loading. The sample filter is stored for 7 days after being removed from the sampler to permit decay of radon and thoron daughter radionuclides. The filter is then analyzed for gross alpha and gross beta radioactivity.

Each sample is screened individually for gross alpha and gross beta activity. A subcontracted analytical laboratory analyzes samples using methods described in Chapter 4.0. Sample analysis results are evaluated as described in Section 3.6.

\subsubsection{Criteria for Air Chemical Emission Sampling}

Air chemical emission sampling for the BOP facilities is performed to comply with criteria established by the Hanford Air Operating Permit or NOCs issued under WAC 173-400 and WAC 173-460. Criteria typically consists of EPA Standard Methods or alternate methods accepted by the agency. The following elements are in place to ensure that sampling for air chemical emissions meet required criteria:

- PNNL EM tracks requirements through an action/tracking plan and performs assessments of required sampling.

- Measurement equipment is procured, acceptance tested, calibrated, and maintained according to an EM Quality Assurance Plan (see Section 5) to ensure that sampling equipment has the capability to perform required measurements.

- Test plans and procedures are developed for measurements taken by PNNL's Effluent Management Group to ensure that measurements meet requirements.

\subsubsection{Liquid Effluent Sampling}

The only BOP facility with required routine liquid effluent sampling is EMSL. Process water from EMSL laboratories is discharged to tanks that must be sampled prior to discharge to the City of Richland POTW. An Industrial Wastewater Permit was issued to EMSL (City of Richland, 1997) before startup and provides the sampling criteria for the stream. The permit also gives discharge limits and reporting criteria. PNNL EM performs liquid effluent sampling at EMSL according to permit criteria. This group also administers a discharge approval process and prepares required monitoring reports in support of the EMSL permit. The following elements are in place to ensure that EMSL liquid effluent sampling takes place as required and that sampling criteria are met:

- The EMSL process sewer system is designed to provide for holdup of wastewater before discharge (holding tanks in effluent pit).

- The process sewer effluent tanks system is designed with a mixing capability (sparging system) to ensure a well-mixed sample.

- PNNL EM has sampling procedures in place that specify sampling constituents, frequency, hold times, preservatives, and other sampling criteria.

- EMSL staff have procedures in place to support sampling (e.g., tank isolation, process effluent tank mixing, approval for discharge).

- PNNL EM has contracts with analytical laboratories to provide for required analysis.

Figure 3.2 is a diagram of the EMSL liquid effluent tanks and sampling system.

aLoss calculations were performed using DEPO Version 2.0 (Wong 1991) originally and Version 4.0 later for updates. A 1-micron AMAD polydisperse aerosol was assumed for the calculations based on the assumption that building operations and controls (HEPA filters) are "normal."

Issued: $3 / 99$

Supersedes: New PNNL-12160: Section 3 


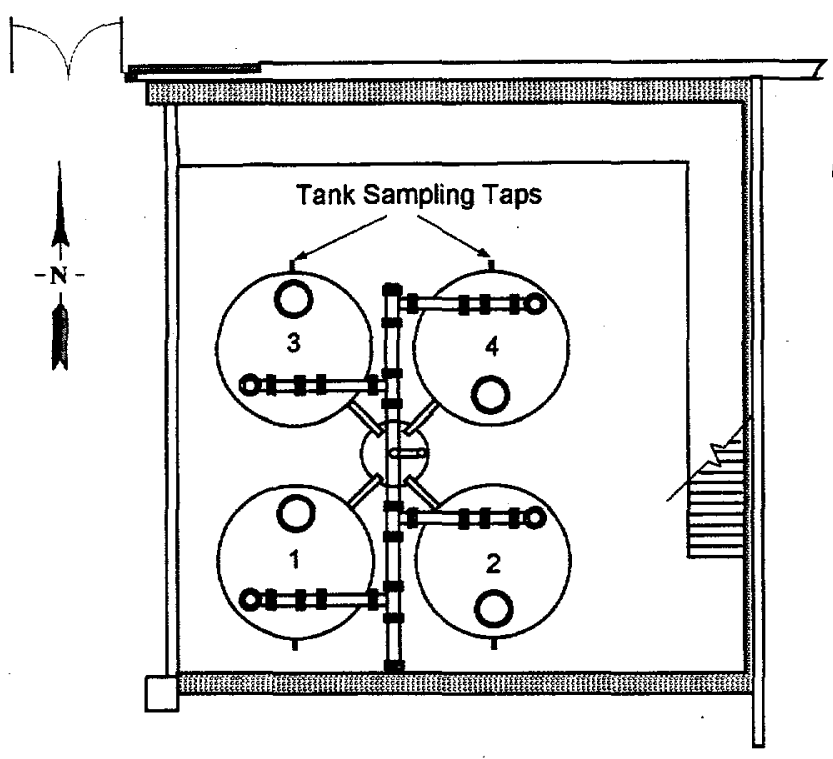

Top View

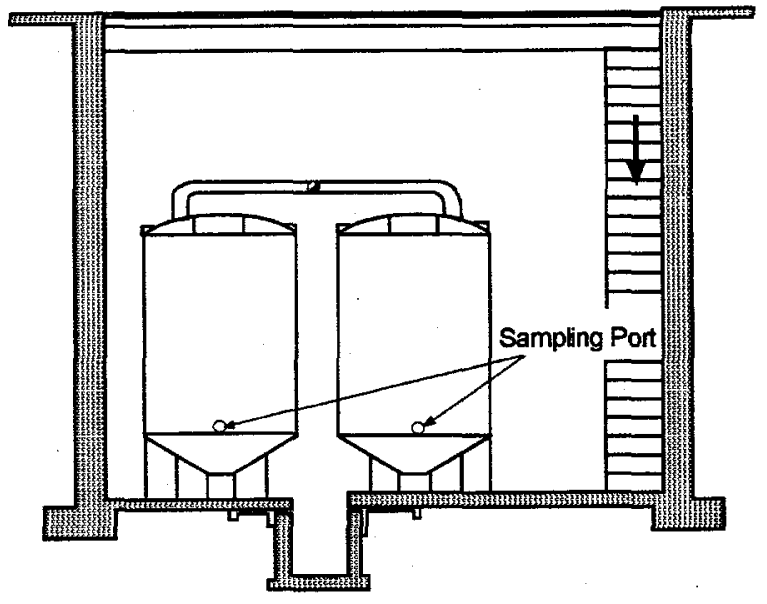

Side View

980800087.10

Figure 3.2 EMSL Process Sewer Tanks

Other BOP facilities have liquid effluent sampling systems $(320,326,329)$ that are used to characterize facility effluents, when needed, and to investigate potential discharges of concern. The primary criteria for these sampling systems have been developed by the TEDF operating contractor and are provided as follows:

- Sampling is required to characterize waste streams discharged to TEDF if process knowledge is inadequate; process knowledge may be used if the facility has only repetitive, well-characterized operations that are consistent over time.

- Characterization sampling must ensure that a valid sample is obtained.

- The number of characterization samples collected must be sufficient to clearly demonstrate that the stream has been adequately characterized.

- Characterization samples shall be analyzed for all classes of constituents not known to be absent from the waste stream.

- Characterization samples shall be collected and handled as specified in a table provided by the TEDF operating contractor. This table lists hold times, minimum sample sizes, sample types (grab/composite), preservatives, and sample containers based on regulatory requirements.

The liquid-effluent sampling systems installed have the ability to take grab or flow-composite samples and are equipped with refrigeration cabinets to ensure preservation temperatures. In addition, PNNL EM has sampling procedures in place and a contract with an analytical laboratory to ensure that sampling requirements are met. Figures 3.3 and 3.4 provide the locations and general schematic of the BOP liquid effluent sampling and monitoring systems. The streams are monitored for flow, $\mathrm{pH}$, and conductivity. 


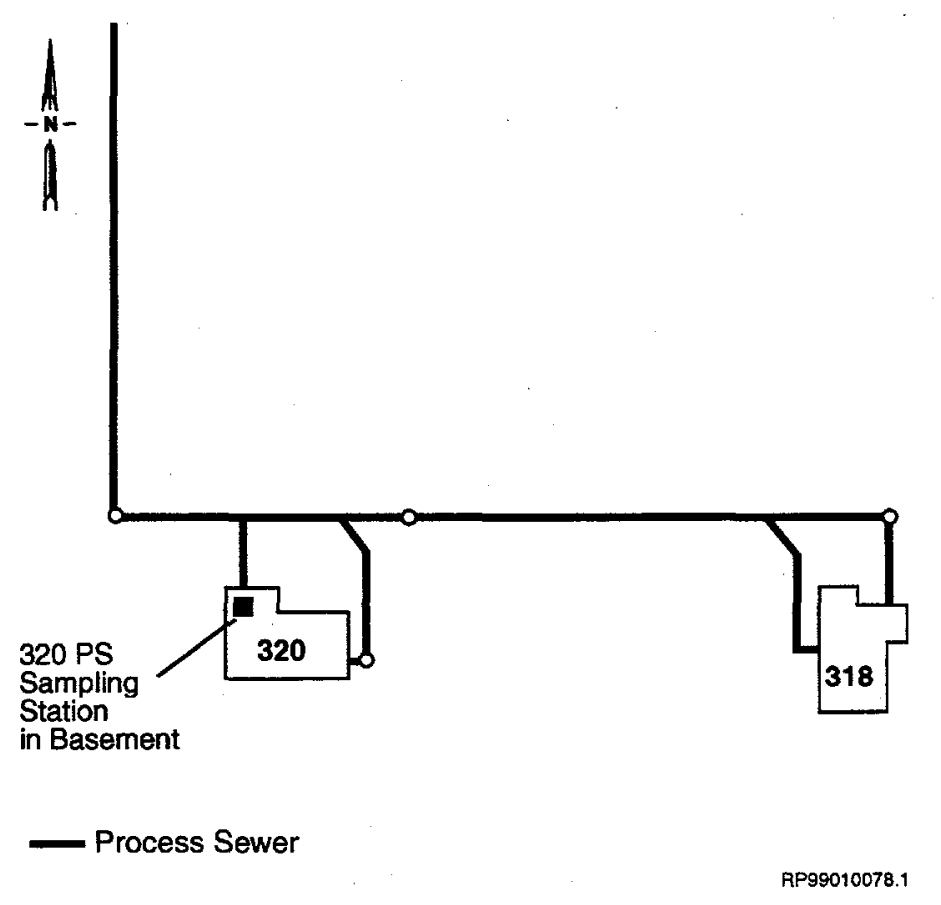

Figure 3.3 Location of the 320 Liquid Effluent Sampling and Monitoring System

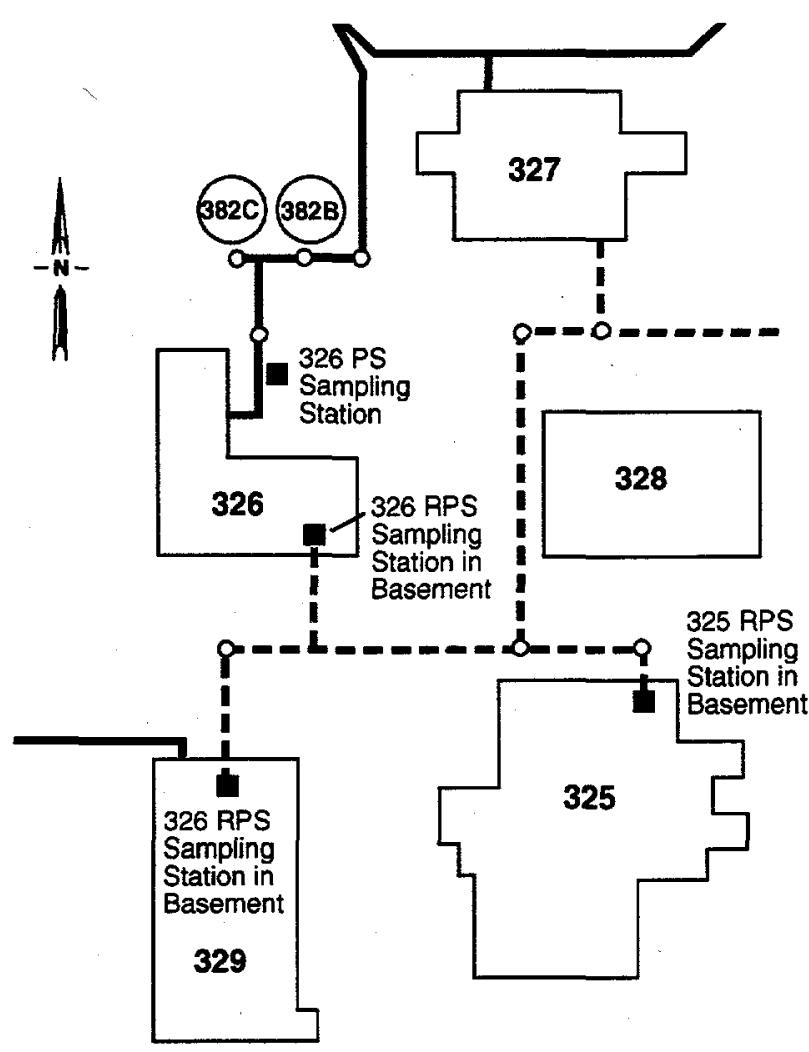

_- Process Sewer

RP99010078.3

Figure 3.4 Location of the 326 and 329 Liquid Effluent Sampling and Monitoring Systems 


\subsection{Sampling System Performance}

\subsubsection{Radiological Air Sampling System Description}

Performance criteria for sampling are provided in Section 3.2.1. One of the criteria concern measurement sensitivity and the other concerns measurement bias. The criteria for bias is based on conformance of the system to design and operational guidance in ANSI (1969) and DOE (1991). System description information is consistent with the design and operational guidance; thus, the bias criterion is met.

Sensitivity criteria for sampling are stated in terms of detectable offsite dose. Per performance criteria in Section 3.2.1, radionuclides shall be detectable at emission levels resuiting in an annual, committed effective dose equivalent of $0.01 \mathrm{mrem} / \mathrm{yr}^{\mathrm{a}}$. Total alpha activity and total beta activity are measured to screen for other radionuclides in the stack exhaust.

The sensitivity of particulate radionuclide sampling is proportional to the collection efficiency of the sampler, the fraction of the emission quantity collected by the sampler, and the level at which the radionuclide can be detected in the collected sample. These values vary depending on the emission point flow rate and sampling system design. Minimum detection levels required by the analytical lab were based on the worst-case facility. (The 325 Building required the lowest detection level because of the high stack flow rate.) Using the MDAs of $1 \mathrm{pCi} / \mathrm{sample}$ alpha and $38 \mathrm{pCi} / \mathrm{sample}$ beta required of the lab, the detectable annual release from each of the BOP minor emission points sampled is shown in Table 3.4. These detectable $\mathrm{Ci}$ of gross alpha and gross beta released are all below the values of $5 \mathrm{E}-5 \mathrm{Ci}$ alpha and $2 \mathrm{E}-3 \mathrm{Ci}$ beta, which would result in a $0.01 \mathrm{mrem} / \mathrm{yr}$ dose. Thus, the BOP Facility stack sampling systems exceed the minimum criteria for detection of radionuclides in emissions.

Table 3.4 Detectable Activity from BOP Minor Emission Points

\begin{tabular}{|c|c|c|}
\hline \multirow{2}{*}{ Emission Point } & \multicolumn{2}{|c|}{ Detectable Annual Release (Ci) } \\
\cline { 2 - 3 } & Gross Alpha & Gross Beta \\
\hline EP-305B-01-S & $1.06 \mathrm{E}-8$ & $4.03 \mathrm{E}-7$ \\
\hline EP-306W-03-V & $3.08 \mathrm{E}-7$ & $1.17 \mathrm{E}-5$ \\
\hline EP-318-01-S & $1.50 \mathrm{E}-7$ & $5.69 \mathrm{E}-6$ \\
\hline EP-320-01-S & $5.61 \mathrm{E}-7$ & $2.13 \mathrm{E}-5$ \\
\hline EP-320-02-S & $2.02 \mathrm{E}-8$ & $7.69 \mathrm{E}-6$ \\
\hline EP-320-03-S & $1.22 \mathrm{E}-8$ & $4.63 \mathrm{E}-7$ \\
\hline EP-320-04-S & $9.68 \mathrm{E}-9$ & $3.68 \mathrm{E}-7$ \\
\hline EP-323-01-S & $1.50 \mathrm{E}-7$ & $5.72 \mathrm{E}-6$ \\
\hline EP-326-01-S & $1.41 \mathrm{E}-6$ & $5.34 \mathrm{E}-5$ \\
\hline EP-329-01-S & $6.31 \mathrm{E}-7$ & $2.40 \mathrm{E}-5$ \\
\hline EP-3730-01-S & $5.18 \mathrm{E}-9$ & $1.97 \mathrm{E}-7$ \\
\hline EP-3745-01-S & $1.32 \mathrm{E}-8$ & $5.01 \mathrm{E}-7$ \\
\hline EP-3020-01-S & $1.41 \mathrm{E}-7$ & $5.34 \mathrm{E}-6$ \\
\hline
\end{tabular}

\subsection{Handling of Sampling Data}

Routine compliance sampling of facility effluents for DOE-owned PNNL-operated facilities are taken for radiological air emissions and liquid-effluent discharges. In addition, periodic sampling or monitoring data on air chemical emissions may be collected to verify, characterize, or investigate effluents. This sampling is performed by PNNL EM. Sampling data are handled according to the following general requirements:

- Chain of custody (COC) forms are generated for each sample to track the sample from collection through disposal. COCs contain the place, date, and time of sampling; who

a The determination of minimum sampler capability is based on a series of worst-case assumptions for exposure scenarios, resulting in calculations of upper bound doses. Thus, the methods used here to evaluate system capability are not appropriate for assessment of actual releases. A realistic assessment of the significance of a sample reading can be made only by considering the actual operational and environmental conditions at the time of the release. 
performed the sampling and measurements; the signature, name, date, and time of transfers; and any applicable special instructions on storage and preservation or reference to a statement of work (SOW) for specific instructions. For field measurements where the measurement is taken immediately (within 15 minutes) and the sample is not transfered, the COC information can be documented in a logbook.

- Data are validated to detect potential quality problems in analytical data. Data are reviewed for 1) results that indicate detectable sample activity or chemical concentration, 2) results above any pre-defined action level, and 3) results that are unexpected.

- Discrepancies, anomalies, unusual data, or data above action levels are investigated and the resolutions documented using a discrepancy report.

- Manipulation of measurement data into a format that will be reported to DOE or regulatory agencies or that will be used as a basis for regulatory decisions is documented to ensure traceability. Technical reviews are performed on calculations involving sampling data to ensure accuracy.

- Sampling data records are maintained according to regulatory requirements that are specified in the effluent management project records inventory and disposition schedule (RIDS).

These general requirements and management specific to data obtained from each activity performed by PNNL's Effluent Management Group (e.g., radiological air emission sampling, air chemical-emission sampling, liquid-effiuent compliance sampling) is documented in an internal group data management plan.

\subsection{Calibration and Maintenance of Equipment}

Sampling and monitoring equipment, including rotameters, are maintained and calibrated according to schedules determined when the equipment is installed or purchased. (Some equipment is user-calibrated before each use.) Calibration and preventative maintenance of installed facility effluent sampling and monitoring equipment are tracked by PNNL maintenance services. PNNL's Effluent Management Group supports calibration and maintenance by helping develop calibration and maintenance procedures, obtaining vendor information on recommended calibration and maintenance or on equipment functions, working with building managers to identify needed repairs, and performing inspections of sampling systems when needed to ensure proper functioning. The following PNNL SBMS Subject Areas provide requirements and guidance pertinent to Calibrations and Maintenance: Service Request Process and Calibration.

\subsection{References}

ANSI 1969. Guide to Sampling Airborne Radioactive Materials in Nuclear Facilities, ANSI N13.1-1969. American National Standards Institute.

ANSI 1980. Specifications and Performance of Onsite Instrumentation for Continuously Monitoring Radioactivity in Effluents, ANSI N42.18 1980b. American National Standards Institute

Ballinger, M.Y., S.J. Jette, and M.J. Sula. 1995. Assessment of Unabated Facility Emission Potentials for Evaluating Airborne Radionuclide Monitoring Requirements at Pacific Northwest National Laboratory 1995. PNL-10855, Pacific Northwest National Laboratory, Richland, Washington.

City of Richland 1996. Richland Pretreatment Program. City of Richland Ordinance 7-96. City of Richland. Richland, Washington.

City of Richland 1997. Industrial Wastewater Permit to Environmental Molecular Sciences Laboratory (EMSL). CR-IU005. City of Richland, Richland, Washington.

DOE 1987. General Design Criteria, DOE 6430.1A, U.S. Department of Energy Order. U.S. Department of Energy. Washington D.C.

DOE 1988. General Environmental Protection Program, DOE 5400.1, U.S. Department of Energy Order. U.S. Department of Energy. Washington D.C. 
DOE 1990. Radiation Protection of the Public and the Environment, DOE 5400.5, U.S. Department of Energy Order. U.S. Department of Energy. Washington D.C.

DOE 1991. Environmental Regulatory Guide for Radiological Effluent Monitoring and Environmental Surveillance, DOE/EH-0173T. U.S. Department of Energy. Washington D.C.

DOE 1997. Environmental Monitoring Plan, DOE/RL-91-50, Rev 2, United States Department of Energy, Richland Operations Office, Richland, Washington.

EPA 1971. Regulations on Standards of Performance for New Stationary Sources, Appendix A: Reference Methods. 40 CFR 60. Environmental Protection Agency, U.S. Code of Federal Regulations.

EPA 1981. National Pollutant Discharge Elimination System Permit-NPDES WA-000374-3. U.S. Environmental Protection Agency. Washington D.C.

EPA 1990. National Emission Standards for Hazardous Air Pollutants. 40 CFR 61. Environmental Protection Agency, U.S. Code of Federal Regulations. 1990.

McCarthy, M. J. 1990. Westinghouse Hanford Company Effluent Report for 300, 400, and 1100 Area Operations for Calendar Year 1989. WHC-EP-0267-1, Westinghouse Hanford Company, Richland, Washington.

Standards Based Management System. SBMS Subject Areas "Service Request Process" and "Calibration," available on Internet at http://sbms.pnl.gov:2080/.

Thompson, C.J., M.Y. Ballinger, E.G. Damberg, and R.G. Riley. 1997. Characterization and Monitoring of 300 Area Facility Liquid Waste Streams During 1994 and 1995, PNNL-11552, Pacific Northwest National Laboratory, Richland, Washington.

WAC 1994. Radiation Protection - Air Emissions, WAC 246-247, Washington Administrative Code. Washington Department of Health.

WDOE and WDOH 1999. Hanford Site Air Operating Permit, HNF-AOP-97-1. Washington State Department of Ecology and Washington State Department of Health. 


\subsection{Laboratory Analyses}

This section provides information on the analytical laboratories and procedures used to analyze samples collected in support of the PNNL effluent monitoring program. As stated in previous sections, these samples may contain radioactivity or chemicals or chemical parameters associated with airbone effluents and liquid discharges.

Section 3.5 describes the types of samples collected throughout the BOP. The laboratories and procedures used to perform sample analyses are described in Section 4.1. Section 4.2 provides a description of procedures employed by PNNL and its supporting analytical laboratories.

\subsection{Analytical Procedures}

Analytical procedures for alpha and beta particulate radioactivity, isotopic analysis, and chemical contaminants are provided in this section. The principal radionuclides potentially found in BOP airborne emissions and liquid effluent are described in Section 3.0. These radionuclides are detectable using procedures described in this section. Analyses are performed by the Radioanalytical Application Team (RAT) of the PNNL Radiochemical Processing Group located in the Radiochemical Processing Laboratory (RPL). All analytical work associated with radionuclide sampling is performed according to required methods per PNNL contract and statement of work (SOW) with the analytical laboratory. The SOW is prepared to meet the QA requirements from 40 CFR 61 (EPA 1990).

\subsubsection{Determination of Alpha and Beta Activity on Particulate Air Filters}

Particulate air filter samples from the BOP sampling systems are collected and are initially delivered to a counting laboratory operated by PNNL's Radiation Protection Section. The samples are held at the laboratory to allow for adequate decay of radon daughter radionuclides.

Following the hold time for radon daughter decay, each particulate filter is delivered to the RPL RAT Analytical services are performed according to documented requirements in a SOW.

Samples are received, logged in, classified, and analyzed according to procedures documented as Standard Operating Procedures (SOPs).

The RPL RAT particulate alpha and beta analysis method are documented in RAT SOPs. Samples are counted on an alpha and beta proportional counter. The counters are operated with a full open energy window and are calibrated using ${ }^{239} \mathrm{Pu}$ and ${ }^{90} \mathrm{Sr}$ sources corrected for self-absorption. As specified in the SOW, required detection levels are 1-pCi/sample alpha and 38-pCi/sample beta activity on a single (2-week sample) filter for Type I and Type II errors of 0.05 . Section 3.5 addresses the performance capability of the particulate emission sampling program in terms of detectable offsite dose.

\subsubsection{Isotopic Analysis}

The record particulate filters analyzed by RAT for alpha and beta, as discussed in Section 4.1 .1 may be further analyzed for ${ }^{90} \mathrm{Sr},{ }^{137} \mathrm{Cs},{ }^{241} \mathrm{Am},{ }^{243} \mathrm{Am},{ }^{238} \mathrm{Pu},{ }^{239 / 240} \mathrm{Pu}$, and ${ }^{241} \mathrm{Pu}$. These analyses are performed by RAT on particulate samples composited on a semi-annual basis.

The RAT composite preparation and analysis methods used for the above isotopes are listed in Table 4.1. As specified in the SOW, required detection levels are also listed in Table 4.1.

Before digesting the particulate filters for isotopic analysis, the filters are grouped on a semi-annual basis in preparation for gamma scan analysis. The semi-annual groups of samples are transferred to a standard geometry container for counting on the gamma detectors. Intrinsic Germanium (high-purity germanium [HPGE]) detectors are used to detect isotopes with gamma ray energies between 60 and $2000 \mathrm{KeV}$. 
Table 4.1 Isotopic Separation and Analysis Methods

\begin{tabular}{|l|c|}
\hline Method & $\begin{array}{c}\text { MDA } \\
\text { (pCi/sample) }\end{array}$ \\
\hline Air Filter Preparation and Compositing & $-\mathrm{NA}-$ \\
\hline Gamma Analysis Sample Preparation, All Matrices & $38^{(1)}$ \\
\hline Electrodeposition Procedure for the Actinides & $-\mathrm{NA}-$ \\
\hline Strontium Determination for 6-month Filter Composites & 38 \\
\hline $\begin{array}{l}\text { Isotopic Plutonium Determination for 6-month Filter } \\
\text { Composites }\end{array}$ & 1 \\
\hline $\begin{array}{l}\text { Isotopic Americium/Curium Determination for 6-month } \\
\text { Filter Composites }\end{array}$ & 0.7 \\
\hline (1)-Based on ${ }^{137} \mathrm{Cs}$, will depend on isotope & \\
\hline
\end{tabular}

Following the gamma scan, the semi-annual groups are digested and the elements of interest are separated from other elements and the sample matrix by chemistry. The ${ }^{90} \mathrm{Sr}$ content is determined by the chemical separation and counting of a daughter element, ${ }^{90} \mathrm{Y}$. The strontium is separated from other elements chemically, then ${ }^{90} \mathrm{Y}$ is permitted to grow into equilibrium with the ${ }^{90} \mathrm{Sr}$. The ${ }^{90} \mathrm{Y}$ is then separated and processed to determine the chemical recovery and counted on a low background beta proportional counter. The quantity of ${ }^{90} \mathrm{Sr}$ is then determined based on the quantity of the daughter ${ }^{90} \mathrm{Y}$ produced.

Plutonium is separated from other elements and the sample matrix by adsorption on an anion exchange column. The plutonium is then processed chemically and electroplated or coprecipitated on rare earth fluorides. Isotopic concentrations of the deposited material is determined by alpha spectrometry. Following the removal of the plutonium, the sample matrix is further processed chemically and the americium and curium removed by passing the sample through a cation exchange column. The americium and curium are eluted from the column and either electroplated or coprecipitated. As with the plutonium, isotopic concentrations of the deposited material is determined by alpha spectrometry.

\subsubsection{Liquid Effluent Samples}

Liquid effluent samples are collected from the EMSL liquid effluent tank pit as necessary to empty the tanks. For some measurements ( $\mathrm{pH}$, conductivity), the analysis is performed in the field using procedures developed by PNNL's Effluent Management Group. For other measurements (chemical constituents), EMSL liquid waste samples are shipped to an analytical laboratory contracted by PNNL.

Non-routine liquid effluent samples may also be collected from EMSL or from other PNNL facilities. Desired analyses for non-routine samples may be performed in the field, at the PNNL Effluent Monitoring laboratory, or shipped to another PNNL analytical laboratory or a commercial analytical laboratory offsite. Analytical procedures may vary depending on the sampling concern. Analyses needed to determine compliance or support compliance decisions are performed using methods accepted by the appropriate regulatory agency.

\subsection{Procedures}

PNNL's Effluent Management Group maintains documented technical and operation procedures for all aspects of effluent monitoring. The SBMS (Technical and Operating Procedures) contains the requirements for preparation, review, and approval of these procedures. EM procedures incorporate all required elements of the subject area.

Sampling procedures include identification of applicable staff, identification of possible hazards encountered while collecting samples, emergency contacts, any applicable prerequisites to performing the work, and work instructions. The work instructions address areas such as equipment operation, sample collection media to be used, amount of sample to be collected, and sample preservatives (as needed). 
Effluent Management maintains documented chain-of-custody procedures for all samples. Procedures include provisions for transfer of samples between operational staff, to and from regulated storage areas, and to the analytical laboratory. Both PNNL and any offsite analytical services contractor implement chain-of-custody within the Laboratory.

The analytical laboratory maintains documented and approved chain-of-custody procedures for the preliminary analyses of particulate emission samples and for record analysis of particulate air filters. Radiological air emission samples are stored for 18 months before being discarded.

\subsection{References}

EPA 1990. National Emission Standards for Hazardous Air Pollutants. 40 CFR 61. Environmental Protection Agency, U.S. Code of Federal Regulations. 1990.

SBMS, Technical and Operations Procedures. 1997. Technical and Operations Procedures. StandardsBased Management System Subject Area (http://sbms.pnl.gov:2080/standard/74/7400t010.htm). Pacific Northwest National Laboratory, Richland, Washington. 
This page intentionally left blank. 


\subsection{Quality Assurance Requirement}

\subsection{Quality Assurance Plan}

A number of Quality Assurance (QA) plans were developed to address QA for the different types of effluent monitoring activities performed by PNNL, including: radiological air, chemical air and water release sampling and monitoring. These plans were integrated into one Effluent Management QA Plan in 1997. This plan addresses QA for all PNNL effluent management activities. The QA program described by the plan is based on the following general requirements and guidance:

- DOE Order 5700.6C, Quality Assurance (DOE 1991a)

- 10 CFR 830.120 Quality Assurance (DOE 1994)

- PNNL Standards-Based Management System Subject Area, Quality Assurance Planning (SBMS, QA Planning)

- DOE Order 5400.1, General Environmental Protection Program (DOE 1988)

- U.S. Environmental Protection Agency (EPA) QAMS-005/80, Interim Guidelines and Specifications for Preparing Quality Assurance Project Plans. (EPA 1980)

- American National Standards Institute/American Society for Quality Control (ANSI/ASQC) E41994, American National Standard Specifications and Guidelines for Quality Systems for Environmental Data Collection and Environmental Technology Programs (ANSI/ASQC 1994).

- DOE/EH-0173T, Environmental Regulatory Guide for Radiological Effluent Monitoring and Environmental Surveillance (DOE 1991b).

In addition, QA requirements specified in permits and regulations, including 40 CFR 61 (EPA 1990), for PNNL effluent sampling or monitoring activities are incorporated into the QA Plan.

\subsection{Internal and External Plan Review}

DOE 5400.1 (DOE 1988) states that the Environmental Monitoring Plan (EMP) will be reviewed annually and updated every 3 years. As a support document to the EMP, the FEMP will also be updated every 3 years. Additionally, this plan will be updated, as necessary, after each major change in facility processes, structure, ventilation and liquid collection systems, monitoring equipment, waste treatment, or a significant change to safety analysis reports or safety assessments. At a minimum, the FEMP assessment will be performed annually.

\subsection{References}

ANSI/ASQC 1994, American National Standard Specifications and Guidelines for Quality Systems for Environmental Data Collection and Environmental Technology Programs. E4-1994. American National Standards Institute/American Society for Quality Control.

DOE 1988. General Environmental Protection Program. DOE Order 5400.1. U.S. Department of Energy Order. U.S. Department of Energy. Washington D.C..

DOE 1991a. Quality Assurance. DOE 5700.6C. U.S. Department of Energy Order. U.S. Department of Energy. Washington D.C..

DOE 1991b. DOE/EH-0173T, Environmental Regulatory Guide for Radiological Effluent Monitoring and Environmental Surveillance. U.S. Department of Energy. Washington D.C..

DOE 1994. Quality Assurance. 10 CFR 830.120. Department of Energy, U.S. Code of Federal Regulations.

EPA 1980. Interim Guidelines and Specifications for Preparing Quality Assurance Project Plans. QAMS005/80. U.S. Environmental Protection Agency. Washington D.C..

EPA 1990. National Emission Standards for Hazardous Air Pollutants. 40 CFR 61. Environmental Protection Agency, U.S. Code of Federal Regulations. 1990. 
SBMS, QA Planning 1997. Quality Assurance Planning. Standards-Based Management System Subject Area (http:// sbms.pnl.gov:2080/standard/87/8700T010.htm). Pacific Northwest National Laboratory, Richland, Washington. 


\subsection{Program Implementation Procedures}

The Hanford Site Environmental Monitoring Plan (EMP) (DOE 1997) documents the effluent-monitoring and environmental surveillance programs for the Hanford Site.

\subsection{Interface with the Near-facility Environmental Monitoring Program}

The EMP divides the effluent-monitoring coverage into two areas, the FEMPs and the Near-Facility Environmental Monitoring Program. The FEMPs cover the monitoring of effluents from facilities at the facility. PNNL's Effluent Management Project maintains implementation procedures for all PNNL facilitymonitoring activities. These procedures meet the PNNL requirements for technical and operating procedures (SBMS, Technical and Operations Procedures) and ensure that facility effluent sampling and monitoring is conducted compliantly. The Near-Facility program monitors air, surface water, groundwater, soil, sediment, vegetation, and biota around site facilities to evaluate the adequacy of effluent control at various facilities at the Hanford Site. The program is conducted by Waste Management Federal Services, Inc. Northwest Operations.

\subsection{Interface with the Operational Environmental Surveillance Program}

Environmental surveillance of the 300 Area and the surrounding onsite and offsite areas is performed by the PNNL Hanford Site Surface Environmental Surveillance Project and the PNNL Site-Wide Groundwater Monitoring Project. These projects are notified in the event of actual or apparent new or off-normal discharges to the soil, surface waters, or air so they can assist in assessing their environmental and compliance significance. The data from these programs are also useful to verify the occurrence or nonoccurrence of facility releases. These surveillance projects are described in detail in DOE (1997).

\subsection{References}

DOE 1997. Environmental Monitoring Plan, United States Department of Energy, Richland Operations Office. DOE/RL-91-50, Rev. 2, U. S. Department of Energy, Richland Washington.

SBMS, Technical and Operations Procedures. 1997. Technical and Operations Procedures. StandardsBased Management System Subject Area (http://sbms.pnl.gov:2080/standard/74/7400t010.htm). Pacific Northwest National Laboratory, Richland, Washington. 
This page intentionally left blank. 


\subsection{Reporting}

This section describes the compliance reporting and notification requirements related to facility effluent monitoring. It also identifies the requirements and provides an overview of the procedural steps for the notification, investigation, and reporting of all environmental off-normal events for PNNL operations.

\subsection{Routine Effluent Monitoring Reports}

On a periodic basis, effluent monitoring data are gathered by PNNL on specific DOE Richland Operations Office (DOE/RL) facilities for compilation and reporting to DOE and the various regulatory agencies.

The following effluent monitoring reports are submitted to regulatory agencies:

\section{Airborne Effluent}

- An Annual NESHAP Air Emissions Report for the Hanford Site providing the required annual emissions measurements and climatological data is submitted to the U.S. Environmental Protection Agency (EPA) and the Washington State Department of Health (WDOH) for the Hanford Site radioactive airborne emissions;

- The Annual Radioactive Effluent and Onsite Discharge Data Report is submitted to DOEHeadquarters, the EPA, and WDOH through DOE-RL after compilation by EG\&G Idaho; and

- Semiannual Reports providing updates of compliance related activities under the Hanford Air Operating Permit (AOP) (WDOE and WDOH 1999) are submitted to WDOE.

- The Annual Compliance Certification is provided to WDOE as to the continuous or intermittent compliance of activities under the AOP.

\section{Liquid Effluent}

- The City of Richland is provided a monthly discharge monitoring report (DMR) for discharges to the City sanitary sewer system from the EMSL Facility (City of Richland 1997);

- WDOE is provided an annual report on significant discharges of hydrotest, maintenance, or construction wastewater discharged to ground as required by permit ST-4508 (WDOE 1997).

- WDOE is provided an annual inventory of miscellaneous liquid effluent discharges to ground as required by WDOE Consent Order DE 91NM-177 (WDOE 1991).

\section{Other}

- WDOE is provided with a monthly status report of all reportable spills from the previous month through RL.

\subsection{Non-routine Notifications and Reports}

There are a number of reports, including notification reports, that are required with respect to effluent monitoring activities.

- A Notice of Construction (NOC) must be provided to WDOH and/or WDOE and/or the Benton Clean Air Authority (BCAA), depending emissions type, whenever a new emission unit is to be created, or if there is to be significant modification to an existing emission unit.

- A Notice of Transient or Abnormal Conditions must be provided to WDOH as soon as practicable in accordance with AOP requirements. A Notification Follow-up Report may also be requested in addition to the initial notification.

- Report of Closure shall be submitted to WDOH whenever an emission unit covered under WAC 246-247 (WAC 1994) ceases emission.

- Notification of Renovation/Demolition Activities Involving Asbestos must be provided to BCAA anytime work involving renovation or demolition activities in a facility with asbestos is planned. 


\subsection{Event Notification and Reporting}

"Events" or conditions may adversely affect DOE or contractor personnel, the public, property, the environment, or the DOE mission. Staff who discover an event that requires mitigation must notify the Battelle single-point-contact to begin the response and mitigation process. Managers who are notified of events within their domain participate in the recovery, evaluation, analysis, and corrective action of the event. These two processes, staff notification and management participation, are described in a PNNL Standards-Based Management System (SBMS) Subject Area (SBMS, Event Reporting). The Subject Area incorporates requirements from DOE 232.1A, "Occurrence Reporting and Processing of Operations Information" (DOE 1997) and associated DOE-RL Directives (RLIDS).

\subsection{References}

SBMS, Event Reporting. 1997. Event Reporting. Standards-Based Management System Subject Area (http:// sbms.pnl.gov:2080/standard/27/2700t010.htm). Pacific Northwest National Laboratory, Richland, Washington.

City of Richland 1997. Industrial Wastewater Permit to Environmental Molecular Sciences Laboratory (EMSL). CR-IU005. City of Richland, Richland, Washington.

DOE 1997. Occurrence Reporting and Processing of Operations Information, DOE 232.1A. U.S. Department of Energy Order. U.S. Department of Energy. Washington D.C..

EPA 1981. National Pollutant Discharge Elimination System Permit. NPDES WA-000374-3. U.S. Environmental Protection Agency

WAC 1994. Radiation Protection - Air Emissions, WAC 246-247, Washington Administrative Code. Washington Department of Health.

WDOE 1991. Consent Order in the Matter of the Compliance by United States Department of Energy with Chapter 70.105 and 90.48 RCW and the Rules and Regulations of the Department of Ecology, DE 91NM-177. Washington State Department of Ecology

WDOE 1997. State Waste Discharge Permit for the Discharge of Hydrotest, Maintenance, and Construction Discharges, ST-4508. Washington State Department of Ecology

WDOE and WDOH 1999. Hanford Site Air Operating Permit, HNF-AOP-97-1. Washington State Department of Ecology and Washington State Department of Health 


\section{Appendix A Information on Current Balance of Plant Facilities}

\section{A.1.0 General BOP Information}

This appendix provides information on the mission, physical description, activities, radiological and chemical inventories, required facility monitoring, and history of measured emissions for all DOE-owned, Pacific Northwest National Laboratory (PNNL)-operated facilities except those with an individual Facility Effluent Monitoring Plan or that are inactive or purely administrative. Table A.1 provides a summary of the current Balance of Plant (BOP) facilities, locations, and uses. Table A.2 provides historic data on dose for unabated potential-to-emit (PTE) for radionuclide releases from BOP facilities for the past 4 years. The methodology is described in Ballinger et al. (1995).

Table A.1 Current BOP Facilities

\begin{tabular}{|c|c|c|c|}
\hline Building & Title & Area & Use \\
\hline $213-J$ & Underground Storage Vault & 200 & Store soil samples \\
\hline 242-B \& BL & Radioactive Particle Research Laboratory & 200 & Inactive \\
\hline 2718-E & Critical Mass Fissile Storage & 200 & Storage \\
\hline $303-C$ & Materials Evaluation Laboratory & 300 & Inactive \\
\hline $303-\mathrm{J}$ & Material Storage Building & 300 & Inactive \\
\hline $305-B$ & Hazardous Waste Storage Facility & 300 & R\&D Waste Operations \\
\hline $306-W$ & Materials Development Building & 300 & R\&D \\
\hline $314 \& 314-B$ & Engineering Development Laboratory & 300 & Inactive \\
\hline $318 \& 318 \mathrm{Tr} / 4$ & Radiological Calibrations Laboratory & 300 & R\&D \\
\hline 320 & Analytical and Nuclear Research Laboratory & 300 & R\&D \\
\hline 323 & Mechanical Properties Laboratory & 300 & R\&D \\
\hline 326 & Materials Science Laboratory & 300 & R\&D \\
\hline 329 & Chemical Sciences Laboratory & 300 & R\&D \\
\hline 332 & Hazardous Waste Interim Holding Facility & 300 & $\begin{array}{l}\text { Service - Packaging } \\
\text { Tests }\end{array}$ \\
\hline 336 & High Bay Testing Facility & 300 & R\&D \\
\hline 337 & Technical Management Center & 300 & Administrative \\
\hline 338 & Prototype Engineering Laboratory & 300 & R\&D \\
\hline 350 & Plant Operations \& Maintenance Facility & 300 & Maintenance Services \\
\hline $350-A$ & Paint Shop & 300 & Maintenance Services \\
\hline $350-B$ & Warehouse & 300 & Storage \\
\hline $350-\mathrm{C}$ & Storage Building & 300 & Storage \\
\hline 350-D & Oil Storage Facility (Waste Handling Facility) & 300 & Storage \\
\hline $\begin{array}{l}3020(\mathrm{EMSL}) \\
\& \mathrm{Trl} 1\end{array}$ & Environmental Molecular Sciences Laboratory & 300 & R\&D \\
\hline 3708 & Radio-analytical Laboratory & 300 & Inactive \\
\hline $3718-A \& B$ & Lab Equipment Central Pool & 300 & Equipment Storage \\
\hline $3718-\mathrm{P}$ & General Storage & 300 & Storage \\
\hline $3718-S$ & Storage Building & 300 & Storage \\
\hline 3730 & Gamma Irradiation Facility & 300 & R\&D \\
\hline 3731 & Lab Equipment Central Pool & 300 & Inactive \\
\hline 3731-A & Graphite Machine Shop & 300 & Inactive \\
\hline $3745 \&$ Trlr 3 & Radiological Calibrations \& Standards Building & 300 & R\&D \\
\hline $3745-A$ & Electron Accelerator Facility & 300 & Inactive \\
\hline 3745-B & Positive Ion Accelerator Facility & 300 & Inactive \\
\hline 3760 & Technical Library & 300 & Administrative \\
\hline 3762 & Technical Security & 300 & Inactive \\
\hline 3764 & Office Building & 300 & Inactive \\
\hline 3767 & Office Building & 300 & Inactive \\
\hline $622-A$ & Elevator Control Building & 600 & Service \\
\hline 622-B & Pilot Balloon Release Building & 600 & R\&D \\
\hline
\end{tabular}




\begin{tabular}{|l|l|l|l|}
\hline Building & Title & Area & Use \\
\hline $622-\mathrm{C}$ & Storage Building & 600 & Storage \\
\hline $622-\mathrm{F}$ & Field Office & 600 & Inactive \\
\hline $622-\mathrm{R}$ & Meteorology Laboratory & 600 & R\&D \\
\hline $6652-\mathrm{C}$, shed, & ALE Laboratories, Observatory, \& Storage & ALE & Inactive \\
D, Dome2, G, & Facilities & & \\
H, I, J, LP, M, & & & \\
UP & & ALE & R\&D \\
\hline $6652-$ Dome1 & ALE Observatory & ALE & R\&D Storage \\
\hline $6652-E$ & Lysimeter Preparation Building & ALE & R\&D \\
\hline $6652-L$ & Bunkers & 700 & Service \\
\hline $747 A \&$ TR1 & Whole Body Counter & 100, & Field R\&D \\
\hline 100,300, and & Lysimeter Plots & 300, & \\
600 Lys & & 600 & \\
\hline 614,614 & Environmental Monitoring Stations & 100, & Environmental Monitoring \\
BYRL, 1614 & & 300, & \\
D3, 3614A, & & 400, & \\
EMS 100, 300, & & 600 & \\
400 & & & \\
\hline
\end{tabular}

Table A.2 PTE for BOP Facilities (mrem/yr)

\begin{tabular}{|c|c|c|c|c|}
\hline Building & 1994 & 1995 & 1996 & 1997 \\
\hline $2718-E$ & 0 & 0 & 0 & 0 \\
\hline $305-B$ & $8.1 \mathrm{E}-4$ & $1.5 \mathrm{E}-4$ & $2.6 \mathrm{E}-3$ & $7.8 \mathrm{E}-4$ \\
\hline $306-W$ & $2.0 \mathrm{E}-2$ & $3.0 \mathrm{E}-3$ & $2.9 \mathrm{E}-3$ & $1.8 \mathrm{E}-2$ \\
\hline 318 & $3.9 E-7$ & $1.4 \mathrm{E}-7$ & $1.5 \mathrm{E}-7$ & $7.7 \mathrm{E}-10$ \\
\hline 320 & $7.3 E-4$ & $1.2 \mathrm{E}-3$ & $7.7 E-4$ & $7.6 \mathrm{E}-4$ \\
\hline 323 & $0^{1}$ & $7.2 \mathrm{E}-5$ & $7.7 \mathrm{E}-5$ & $1.7 \mathrm{E}-4$ \\
\hline 326 & $1.6 \mathrm{E}-4$ & $1.8 \mathrm{E}-4$ & $3.5 \mathrm{E}-5$ & $3.9 E-5$ \\
\hline 329 & $2.1 \mathrm{E}-2$ & $1.7 \mathrm{E}-2$ & $9.7 \mathrm{E}-3$ & $3.5 \mathrm{E}-3$ \\
\hline 3020 & $\mathrm{ND}^{2}$ & ND & ND & 0 \\
\hline 3730 & $2.1 E-4$ & $2.0 \mathrm{E}-4$ & $3.0 \mathrm{E}-4$ & $3.9 E-4$ \\
\hline 3745 & $9.5 E-5$ & $9.5 \mathrm{E}-5$ & $9.3 E-5$ & $5.4 \mathrm{E}-5$ \\
\hline $622-R$ & 0 & 0 & 0 & 0 \\
\hline 6652 & $1.1 \mathrm{E}-7$ & $1.1 \mathrm{E}-7$ & 0 & 0 \\
\hline $747-A$ & $6.3 E-9$ & $8.2 \mathrm{E}-12$ & 0 & 0 \\
\hline
\end{tabular}

\section{A.2.0 Building-Specific Information}

\section{A.2.1 213-J}

Mission and Activities: The underground storage vault is used to store soil samples.

Physical Description: The storage vault is a reinforced concrete structure with about 500 square feet of space. It is not equipped with a ventilation system, water supply, liquid effluent system, or air and water sampling systems.

Radiological Inventory: None. Radiological materials are not permitted within this facility. 
Chemical Inventory: The only chemicals present are those associated with the samples stored.

Emission History: N/A. No monitoring or sampling of facility effluents has been required, and no historic data exist.

\section{A.2.2 2718-E Building}

Mission and Activities: The Critical Mass Fissile Storage facility is currently used only as storage for some Light Water Reactor (LWR) fuel rods.

Physical Description: The 2718-E building is in the 200-E Area and has about 2,000 square feet of floor space. The building is steel framed.

Radiological Inventory: Kilogram quantities of LWR fuel rods are stored in the building. The 1997 PTE from 2718-E was $0 \mathrm{mrem} / \mathrm{yr}$, see Table A.2.

Chemical Inventory: No chemicals are currently being used in the facility.

Emissions History: N/A. No monitoring or sampling of facility effluents has been required and no historic data exists.

\section{A.2.3 305-B Building}

Mission and Activities: The Hazardous Waste Storage (305-B) Building is used to receive, store, and prepare shipments of dangerous waste and radioactive mixed waste (RMW) generated by Hanford Site programs. These wastes are primarily generated in support of research and development (R\&D) activities. Wastes are brought to 305-B Building and segregated by compatibility for storage in the unit until enough waste is accumulated to fill a lab-pack or bulking container, usually a 30- to 55-gallon drum. When a sufficient number of shipping containers of waste has accumulated, they are manifested for shipment, generally to permitted offsite recycling, treatment, or disposal facilities. Dangerous wastes are stored in the high bay; RMW is stored in the basement of the original wing of the building. The building is a permitted treatment, storage, and disposal facility (TSDF).

Physical Description: This approximately 10,000-square-foot building consists primarily of high-bay dry laboratory space with associated storage space and an administrative office wing. A fume hood is available for repackaging activities, and radioactive air emissions from the fume hood are high-efficiency particulate air (HEPA)-filtered. A sampling system is available to sample particulate material emitted from the hood. Figure A.1 is a simplified drawing of the ventilation and air emission sampling systems.

Sampling system configuration drawings have been developed and are maintained in PNNL's Essential Drawings System.

The 305-B building is connected to the 300 Area sanitary sewer system (SNS), but processing and storage areas do not have any sewer system access points.

Radiological Inventory: $305-\mathrm{B}$ may house a number of different radionuclides in various forms, depending on PNNL activities in a given year. Small quantities (milli-curie or less) of radionuclides in the form of contaminated solids, liquids, or dispersible solids may be present. The 1997 potential-to-emit (PTE) from 305-B was 7.8E-4 mrem/yr, see Table A.2.

Chemical Inventory: A number of different chemicals may be present in 305-B, depending on the waste materials generated from PNNL R\&D activities.

Emission History: Monitoring for radioactive air emissions from 305-B was initiated in 1996. Table 3.1 shows the estimated emissions for 1996 and 1997. A notice of construction (NOC) was obtained in 1996 for repackaging work performed in the fume hood. Because 305-B does not have sewer access points from the processing and storage areas, wastewater from the building has not been monitored. 


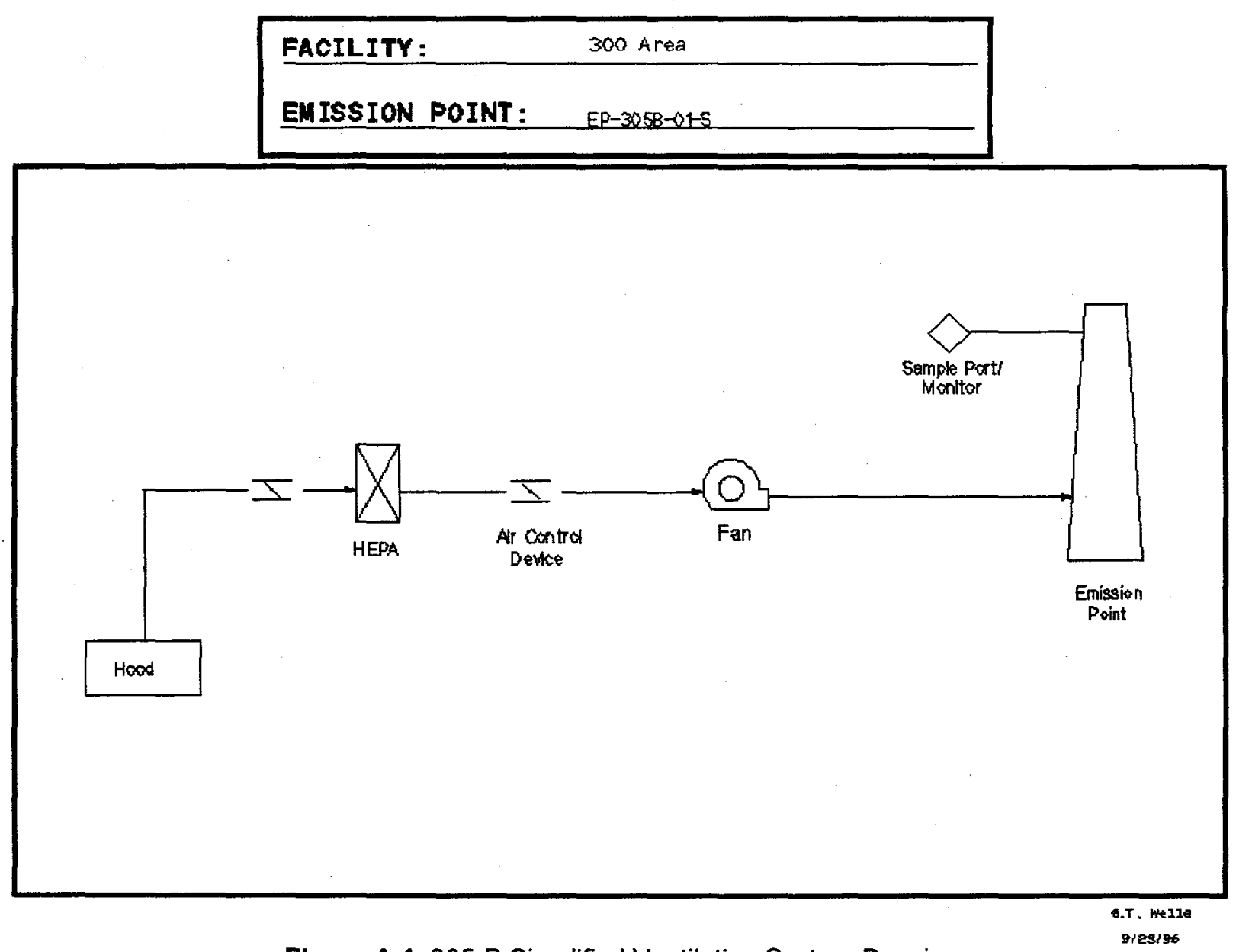

Figure A.1 305-B Simplified Ventilation System Drawing

\section{A.2.4 306-W Building}

Mission and Activities: In the past, this building has been used for research programs involving metal processing and component fabrication such as the U.S. Army's depleted uranium penetrator program and the USCAR initiative. The penetrator program involved the heat treatment, forming, and machining of depleted uranium bars into penetrator designs. The USCAR initiative supported the research and development of lightweight metal matrix composite materials and superplastic aluminum material for major domestic automotive manufacturers. This work included advanced casting technology, testspecimen fabrication, and material testing of the metal matrix composite material and the heat treatment, machining, and testing of the superplastic aluminum material. Some metal work and storage of bulk metal still occurs in the building, but a large portion of the building has been shut down. In addition to the residual metal work, the building is used for PNNL waste-operations activities, including catalytic electrochemical oxidation (a waste treatment process), X-ray and low-level waste repackaging, redistribution of chemical inventories, and waste storage and treatment, shipping, and receiving.

Physical Description: The 306-W Building is a two-story steel-framed structure with about 36,000 square feet of floor space, including large high-clearance process areas for metal working and a two-story office addition. The building has four emission points for radioactive air emissions, but three of these have been capped off when a large portion of the building was shut down in 1996 as part of the PNNL facility transition project. The single emission route left is equipped with HEPA filtration and a sampling system that samples for particulate material. Figure A.2 is a simplified drawing of the ventilation and air emission sampling systems. Ventilation and sampling system configuration drawings have been developed and are maintained in PNNL's Essential Drawings System. 
FACILITY: $\quad 300$ Area

EMISSION POINT :

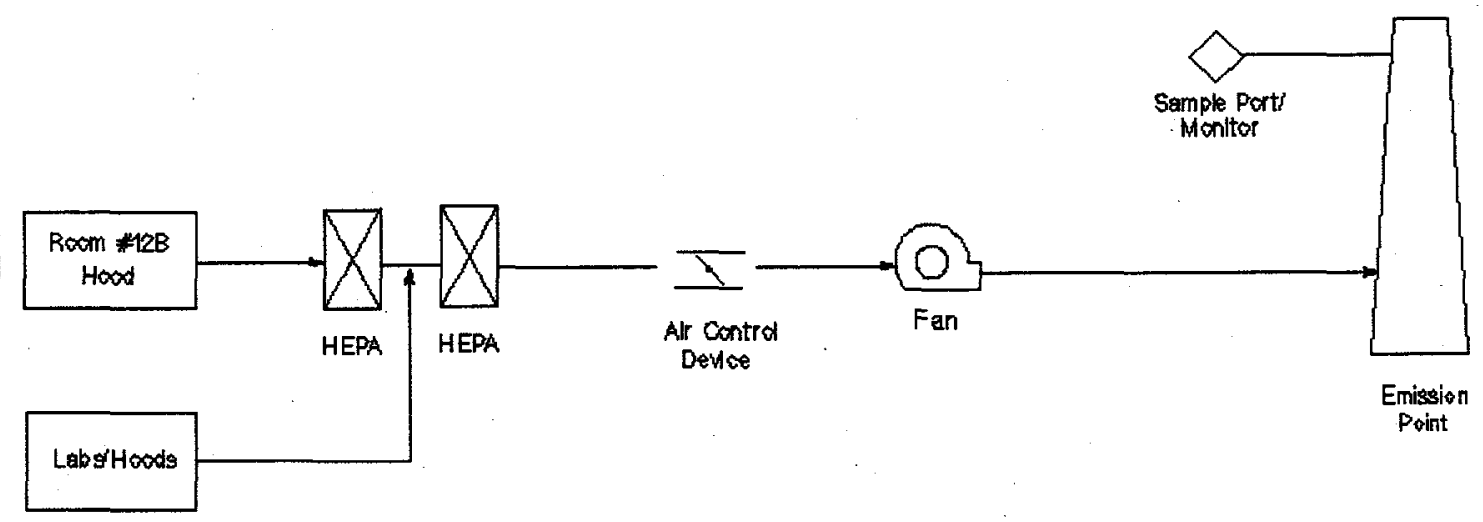

Figure A.2 306-W Simplified Ventilation System Drawing

The building is served by the 300 Area process sewer (PS) and SNS; the SNS serves the restrooms, and lunch rooms and the PS serves process areas. Effluent Management (EM) has a list of PS access points. The building is also equipped with a closed-loop cooling system. In the past, failure of this system has resulted in the triggering of single-pass cooling, causing large quantities of water to be discharged to the process sewer. However, this failure mode was corrected in 1996, eliminating the potential for this discharge.

Radiological Inventory: Radiological inventories include large quantities of depleted uranium bulk metal alloy, smaller quantities of enriched uranium in the building exhaust as holdup from previous operations, and some sealed sources. The 1997 PTE for the building was $1.8 \mathrm{E}-2 \mathrm{mrem} / \mathrm{yr}$, see Table A.2.

Chemical Inventory: A variety of types and forms of chemicals are used in the building.

Emission History: Radioactive air emissions have been and continue to be measured. Radionuclide air emission data since 1991 are shown in Table 3.1. Monitoring of $\mathrm{CO}_{2}$, total organic carbon, and gas chromatograph measurements of the Catalytic Electrochemical Oxidation Waste Treatment Unit emissions are required by an NOC issued by the Washington State Department of Ecology (WDOE) (WDOE 1998).

Although this building does not have a liquid-effluent sampling system, the PS was sampled with a portable sampler during the sampling campaign conducted by PNNL EM in 1994 and 1995 (Thompson et al. 1997). No continued liquid effluent sampling is required for this facility. Table A.3 provides a summary of the results of the sampling campaign. These results show generally low concentrations (parts per billion [ppb]) of pollutants, less than the sewer system waste acceptance criteria.

Table A.3 Constituents Detected in Building 306 Samples 


\begin{tabular}{|c|c|c|c|c|}
\hline \multirow[t]{2}{*}{ Constituent } & \multirow[t]{2}{*}{ Frequency $^{\top}$} & \multicolumn{3}{|c|}{ Concentration $(\mu \mathrm{g} / \mathrm{L})^{2}$} \\
\hline & & Range & Average & $\begin{array}{l}\text { Standard } \\
\text { Deviation }\end{array}$ \\
\hline \multicolumn{5}{|c|}{ General Chemical Parameters } \\
\hline Alkalinity & $7 / 7$ & $60,000-120,000$ & 83,000 & 25,000 \\
\hline $\begin{array}{l}\text { Chemical Oxygen } \\
\text { Demand }\end{array}$ & $7 / 7$ & $4500-13,000$ & 9000 & 2800 \\
\hline Conductivity & $8 / 8$ & $170-320$ & 230 & 55 \\
\hline $\mathrm{PH}$ & $8 / 8$ & $6.2-8.3$ & 7.4 & 0.87 \\
\hline Total carbon & $8 / 8$ & $18.000-30.000$ & 23.000 & 4500 \\
\hline $\begin{array}{l}\text { Total dissolved } \\
\text { solids }\end{array}$ & $7 / 7$ & $100,000-180,000$ & 140,000 & 34,000 \\
\hline $\begin{array}{l}\text { Total organic } \\
\text { carbon }\end{array}$ & $8 / 8$ & $2000-15,000$ & 4600 & 4300 \\
\hline \multicolumn{5}{|c|}{ Ammonia and Anions } \\
\hline Ammonia & $4 / 7$ & $40-100$ & 58 & 29 \\
\hline Chloride & $7 / 7$ & $4700-12,000$ & 7300 & 2500 \\
\hline Fluoride & $6 / 7$ & $230-460$ & 350 & 100 \\
\hline Nitrate & $7 / 7$ & $1500-14,000$ & 7900 & 4800 \\
\hline Sulfate & $7 / 7$ & $13,000-23,000$ & 17,000 & 2900 \\
\hline Sulfides & $3 / 7$ & $220-300$ & 270 & 46 \\
\hline \multicolumn{5}{|c|}{ Metals } \\
\hline Aluminum & $6 / 8$ & $33-190$ & 74 & 60 \\
\hline Arsenic & $1 / 8$ & - & 2.8 & - \\
\hline Barium & $8 / 8$ & $26-43$ & 34 & 5 \\
\hline Beryllium & $1 / 8$ & - & 0.19 & - \\
\hline Calcium & $8 / 8$ & $22,000-41,000$ & 30,000 & 6800 \\
\hline Chromium & $1 / 8$ & - & 5.0 & - \\
\hline Copper & $8 / 8$ & $9.4-56$ & 20 & 17 \\
\hline Iron & $8 / 8$ & $160-910$ & 350 & 320 \\
\hline Lead & $3 / 8$ & $3.2-7.2$ & 5.4 & 2.0 \\
\hline Magnesium & $8 / 8$ & $4800-8800$ & 6500 & 1400 \\
\hline Manganese & $8 / 8$ & $7.2-27$ & 16 & 6.4 \\
\hline Mercury & $2 / 8$ & $0.083-0.084$ & 0.084 & - \\
\hline Potassium & $8 / 8$ & $1200-3100$ & 1900 & 710 \\
\hline Selenium & $1 / 8$ & - & 0.73 & - \\
\hline Silver & $1 / 8$ & - & 3.6 & - \\
\hline Sodium & $8 / 8$ & $3400-11,000$ & 6300 & 2600 \\
\hline Thallium & $1 / 8$ & - & 0.88 & - \\
\hline Zinc & $8 / 8$ & $66-280$ & 110 & 77 \\
\hline \multicolumn{5}{|c|}{ Volatile Organic Compounds } \\
\hline Acetone & $2 / 9$ & $14-15$ & 15 & - \\
\hline Bromoform & $1 / 9$ & - & 2.0 & - \\
\hline Chloroform & $8 / 9$ & $0.9-1.8$ & 1.4 & 0.3 \\
\hline Methylene chloride & $2 / 9$ & $1.1-1.2$ & 1.1 & - \\
\hline \multicolumn{5}{|c|}{ Radiological Parameters } \\
\hline Gross Alpha & $8 / 8$ & $0.93-6.4$ & 3.5 & 0.56 \\
\hline Gross beta & $6 / 8$ & $2.4-20$ & 7.0 & 2.7 \\
\hline Tritium & $3 / 8$ & $290-690$ & 430 & 130 \\
\hline
\end{tabular}

\section{A.2.5 318 Building}

Mission and Activities: The 318 Building is primarily used to provide technical services in internal dosimetry, external dosimetry, instrument calibration, repair, and testing for 1) protecting the health of 
workers and the public and 2) providing liability protection for government and industrial customers. Research in the building includes development of radiation detection and measuring instruments.

Physical Description: The 318 Building has about 37,000 square foot of floor space in a two-story building with a basement. The basement area contains an X-ray room and control room, a high-exposure room, and a mechanical equipment room. The first floor contains a low-scatter room, laboratories, and a small computer room. The second floor contains offices, a lunchroom, and a mechanical equipment room.

Fume hoods are provided in the building for airborne emissions. Exhaust air is not equipped with HEPA filtration. The building has one emission point and an isokinetic radioactive air sampling system that samples for particulate material. Figure A.3 is a simplified drawing of the ventilation and air emission sampling systems. Sampling system configuration drawings have been developed and are maintained in PNNL's Essential Drawings System.

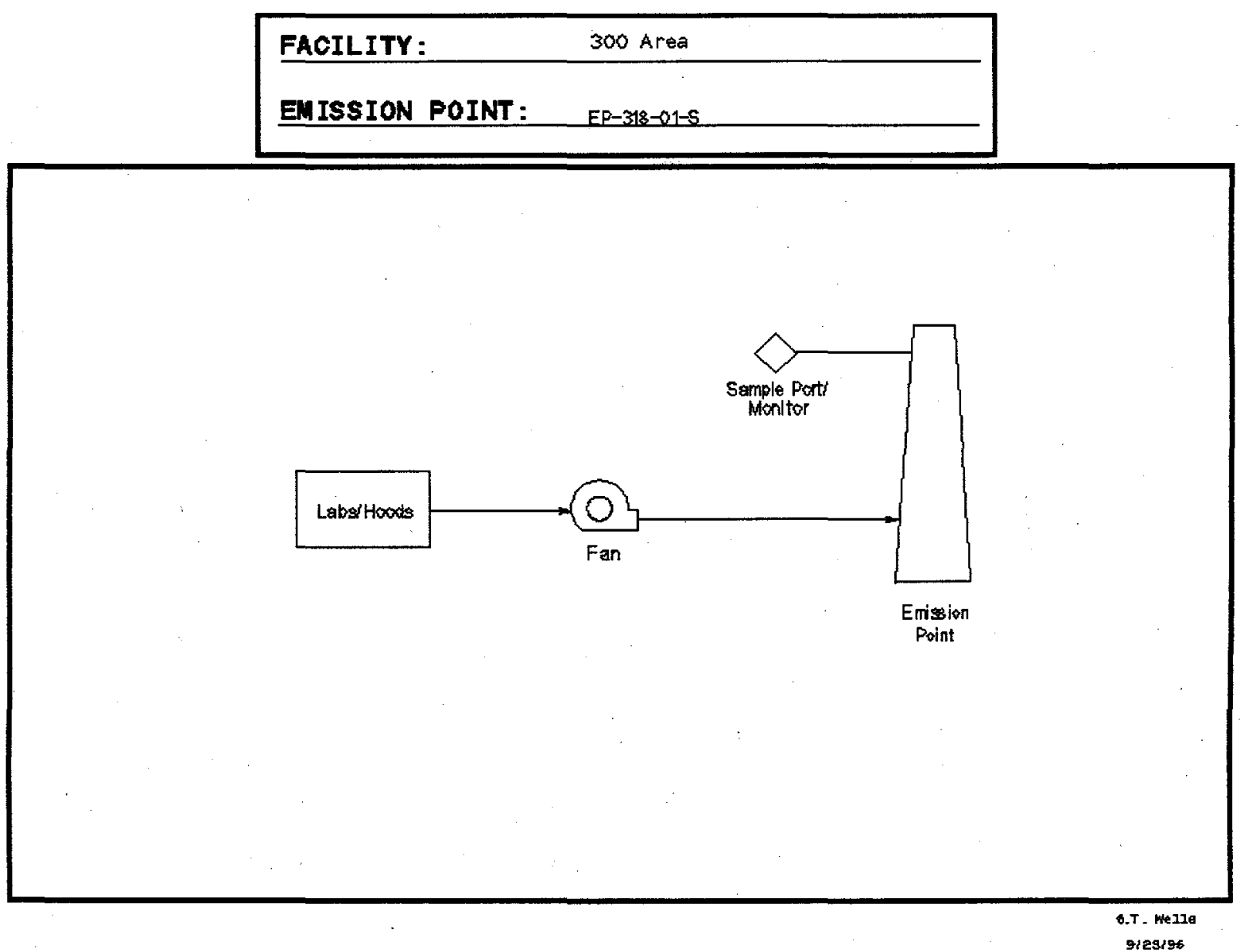

Figure A.3 318 Simplified Ventilation System Drawing

The building is served by the 300 Area PS and SNS; the SNS serves the restrooms, and lunch rooms and the PS serves process areas. EM has a list of PS access points. No liquid effluent sampling system exists for the facility.

Radiological Inventory: Most of the radiological inventory is in the form of sealed sources, although very small quantities of radon and thoron gases are emitted during some calibrations. Also, micro-curie or less quantities of various radioactive materials may also be present in the form of check sources, dispersible solids, or liquids. The 1997 PTE for the building was $7.7 \mathrm{E}-10 \mathrm{mrem} / \mathrm{yr}$, see Table A.2.

Chemical Inventory: A variety of types and forms of chemicals are used in the building. 
Emission History: Radioactive air emissions have been and continue to be measured. Radionuclide air emission data since 1991 are shown in Table 3.1.

Liquid effluents from the 318 Building have not been sampled. With few dispersible radioactive materials and minor quantities of hazardous chemicals, the potential for effluent release to the PS or SNS is considered low.

\section{A.2.6 320 Building}

Mission and Activities: Research activities conducted in the 320 Building involve special-purpose separation and analytical chemistry techniques that allow measurement of low-level and ultra-trace levels of material in environmental samples. Working with samples containing low/trace levels requires special building features, such as a clean zone. A class 10000 clean zone allows for contamination-free preparation and analysis of samples containing extremely low levels of indicator radionuclides and trace organic compounds. Special instrumentation that is used for sample analysis include various mass spectrometers, electron-beam microscopes, X-ray diffraction, and radiation counters.

Physical Description: The 320 Building consists primarily of two floors, one ground level and a basement. A self- contained addition was added consisting of four labs and eight offices attached at both levels to the west end of the older building. Three small equipment rooms are located in the new addition with one large equipment room in the older portion using the south east corner of the basement. Half of the older portion ground-level laboratory space is "clean zone" modular rooms with HEPA filtered supply air. The total square footage for the building is about 31,000 .

The 320 Building has four emission points, and each emission point has a particulate sampling system. All four Emission points are HEPA filtered. Figures A.4-A.7 are simplified drawings of the ventilation and air-emission sampling systems. Sampling system configuration drawings have been developed and are maintained in PNNL's Essential Drawings System.

The building is served by the 300 Area PS and SNS; the SNS serves the restrooms and lunch rooms, and the PS serves process areas. Effluent Management has a list of PS access points. The building is equipped with a liquid effluent sampling system on the PS that includes capability for continuously monitoring $\mathrm{pH}$, conductivity, and flow, as well as capability for obtaining flow-composite samples.

Radiological Inventory: The 320 building has small quantities (millicuries or less) of radioactive materials in various forms. The 1997 PTE for the building was $7.6 \mathrm{E}-4 \mathrm{mrem} / \mathrm{yr}$, see Table A.2.

Chemical Inventory: A variety of types and forms of chemicals are used in the building.

Emission History: Radioactive air emissions have been and continue to be measured. Radionuclide air emission data since 1991 are shown in Table 3.1.

This building is equipped with a liquid effluent sampling system for the PS and was sampled during the sampling campaign conducted by PNNL EM in 1994 and 1995 (Thompson et al. 1997). No continued liquid effluent sampling is required for this facility. Table A.4 provides a summary of the results of the sampling campaign. These results show generally low concentrations $(\mathrm{ppb})$ of pollutants, less than the sewer system waste acceptance criteria. 


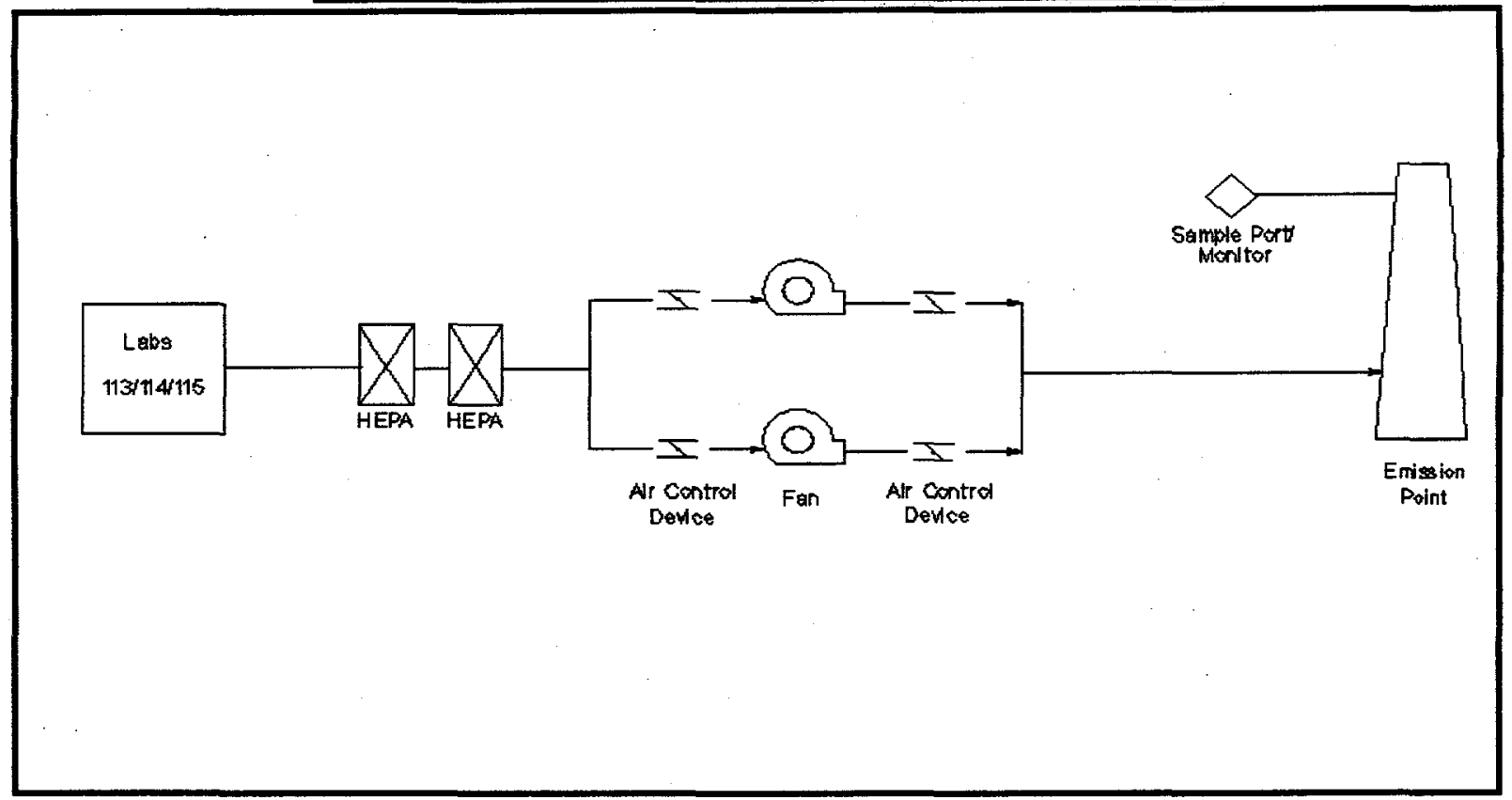

Figure A.4 320-01 Simplified Ventilation System Drawing

FACILITY: 300 Area

\section{EMISSION POINT:} $E P-320-\infty 2-5$

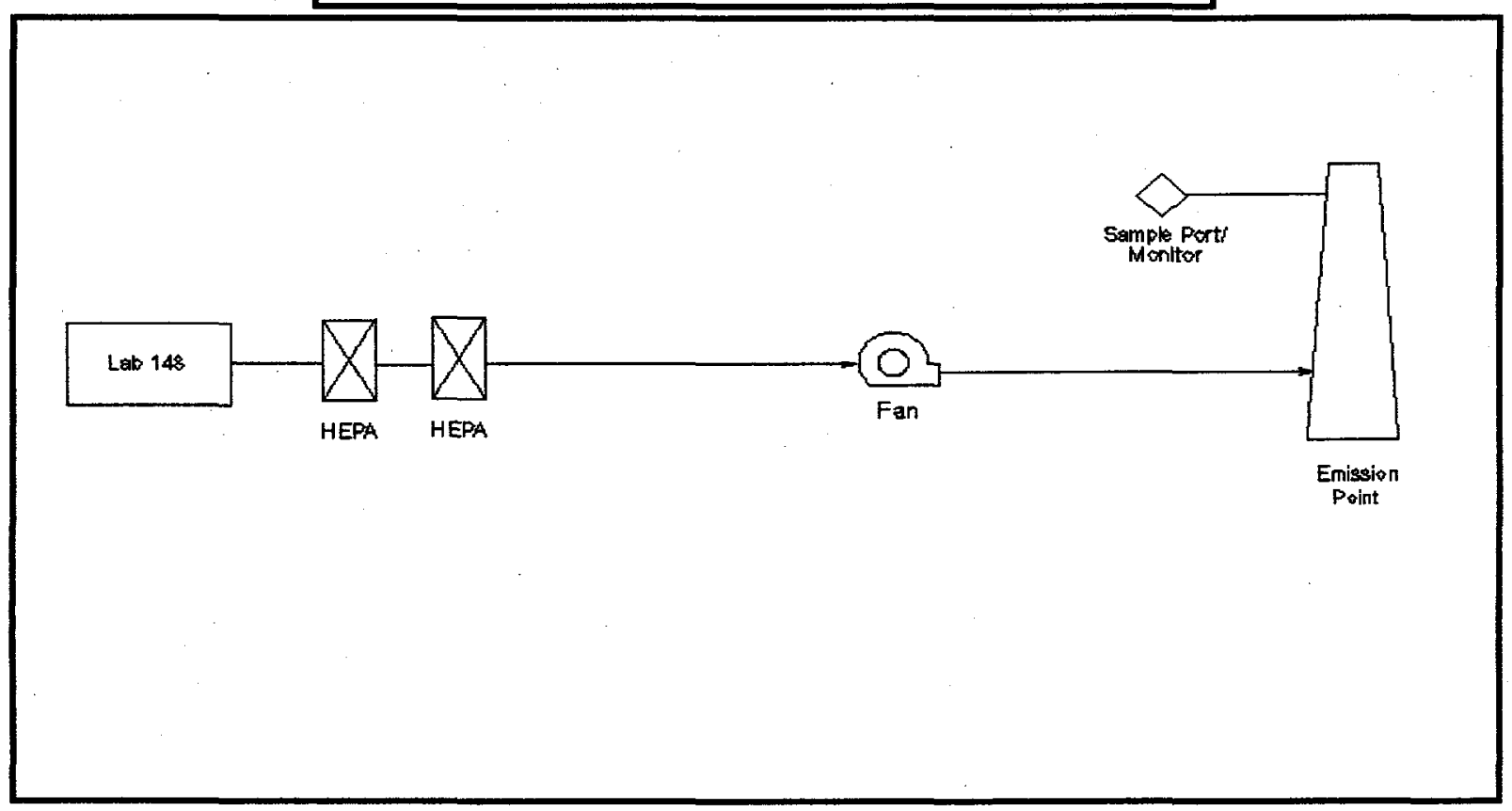

Figure A.5 320-02 Simplified Ventilation System Drawing 


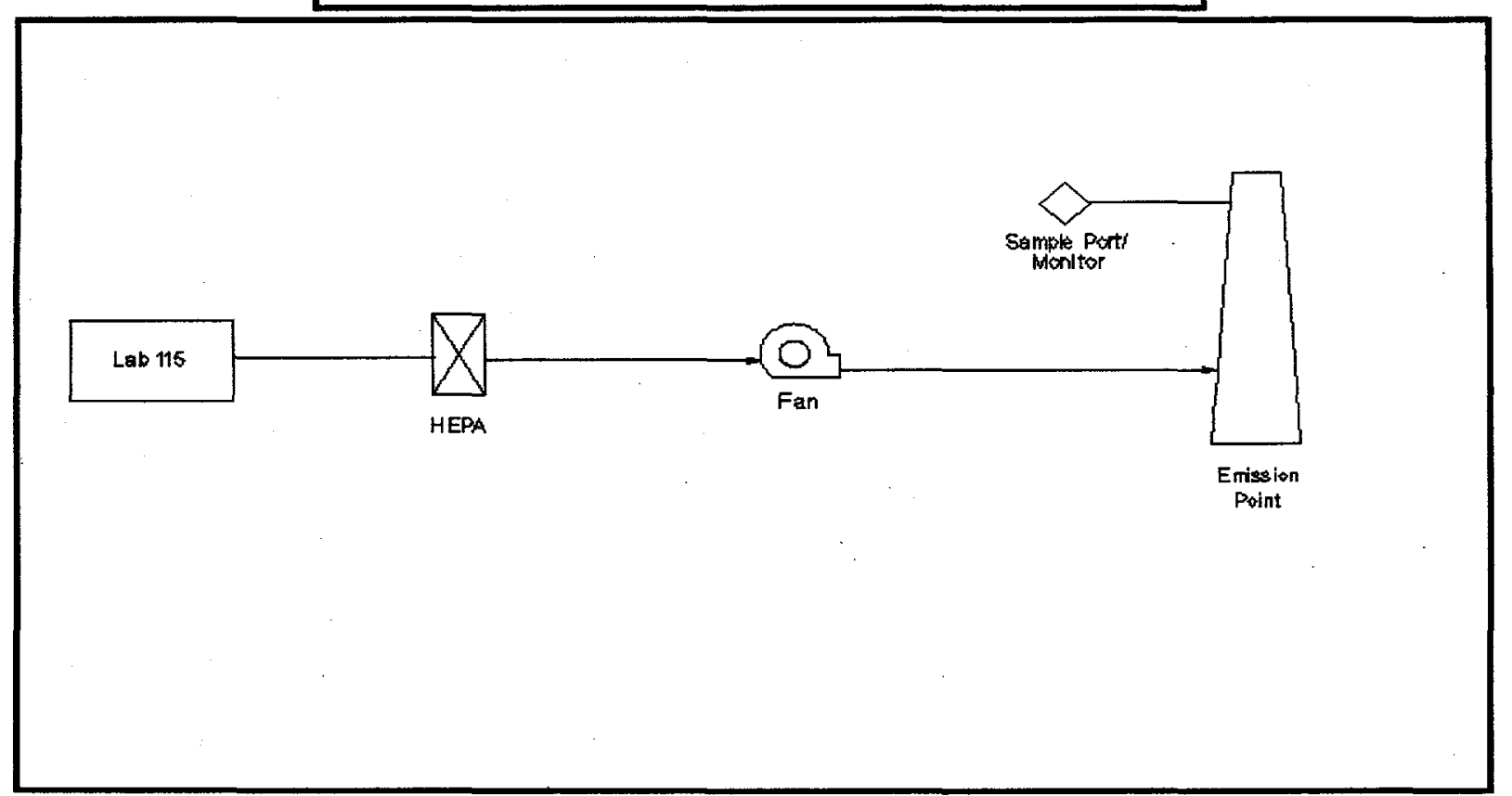

Figure A.6 320-03 Simplified Ventilation System Drawing

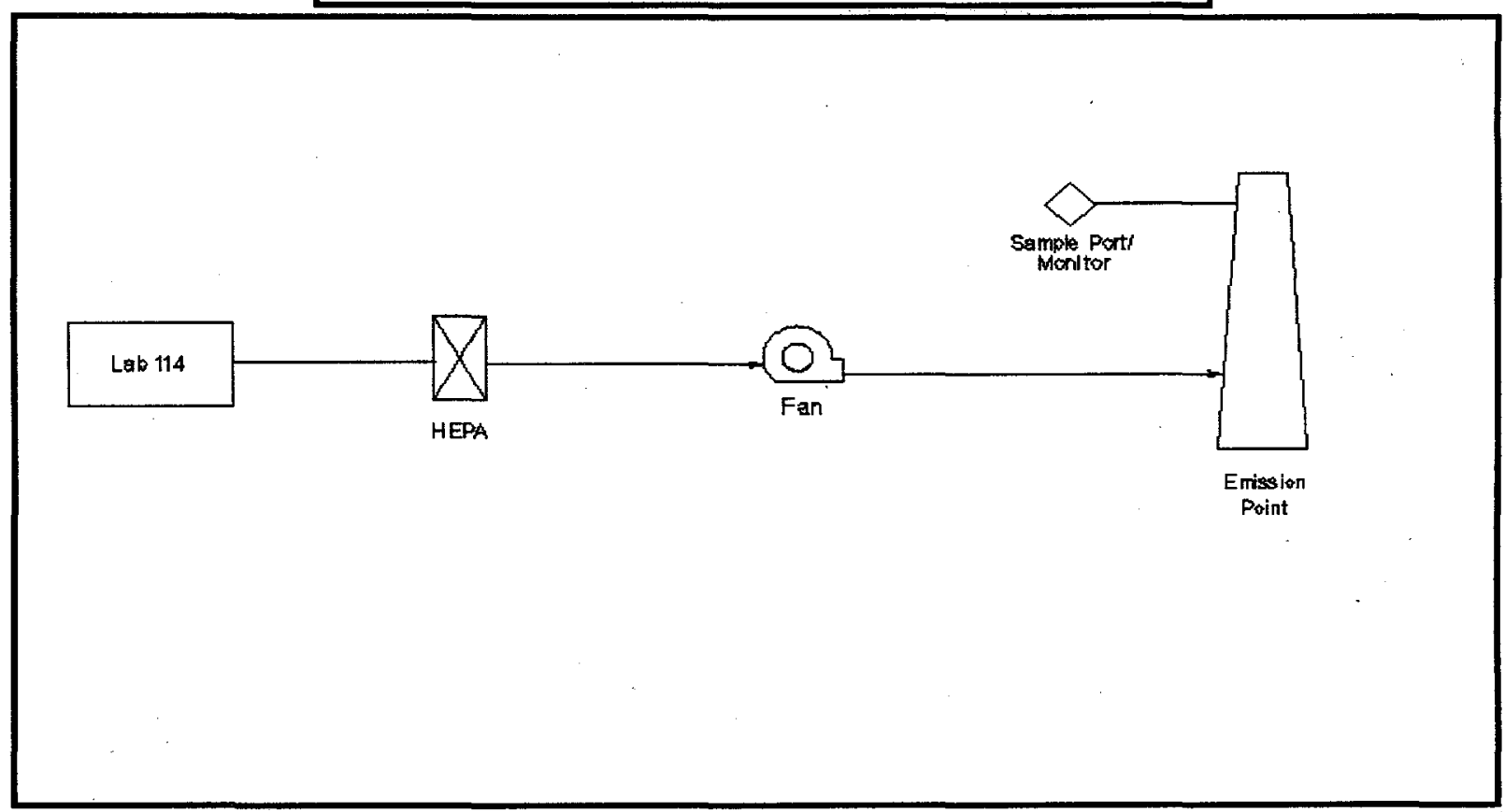

Figure A.7 320-04 Simplified Ventilation System Drawing 
Table A.4 Constituents Detected in Building 320 Samples

\begin{tabular}{|c|c|c|c|c|}
\hline \multirow[t]{2}{*}{ Constituent } & \multirow[t]{2}{*}{ Frequency $^{\top}$} & \multicolumn{3}{|c|}{ Concentration $(\mu \mathrm{g} / \mathrm{L})^{2}$} \\
\hline & & Range & Average & $\begin{array}{l}\text { Standard } \\
\text { Deviation }\end{array}$ \\
\hline \multicolumn{5}{|c|}{ General Chemical Parameters } \\
\hline Alkalinity & $38 / 38$ & $6,000-130,000$ & 58,000 & 20,000 \\
\hline $\begin{array}{l}\text { Chemical Oxygen } \\
\text { Demand }\end{array}$ & $9 / 38$ & $2600-13,000$ & 6300 & 3400 \\
\hline Conductivity & $31 / 31$ & $58-940$ & 200 & 180 \\
\hline $\mathrm{PH}$ & $31 / 31$ & $5.5-10$ & 7.9 & 0.8 \\
\hline Total carbon & $38 / 38$ & $11,000-31,000$ & 16,000 & 4000 \\
\hline $\begin{array}{l}\text { Total dissolved } \\
\text { solids }\end{array}$ & $38 / 38$ & $70,000-210,000$ & 100,000 & 31,000 \\
\hline $\begin{array}{l}\text { Total organic } \\
\text { carbon }\end{array}$ & $39 / 39$ & $1000-3000$ & 1800 & $63 \overline{0}$ \\
\hline \multicolumn{5}{|c|}{ Ammonia and Anions } \\
\hline Ammonia & $4 / 43$ & $30-40$ & 33 & 5 \\
\hline Chloride & $41 / 41$ & $2100-12,000$ & 4700 & 1800 \\
\hline Cyanide & $2 / 39$ & $2-20$ & 11 & . - \\
\hline Fluoride & $38 / 41$ & $230-700$ & 480 & 130 \\
\hline Nitrate & $41 / 41$ & $100-16,000$ & 1700 & 3200 \\
\hline Sulfate & $41 / 41$ & $10,000-24,000$ & 16,000 & 2200 \\
\hline Sulfides & $9 / 38$ & $220-400$ & 300 & 50 \\
\hline \multicolumn{5}{|c|}{ Metals } \\
\hline Aluminum & $39 / 43$ & $29-170$ & 66 & 34 \\
\hline Antimony & $2 / 43$ & $37-39$ & 38 & - \\
\hline Arsenic & $1 / 39$ & - & 0.73 & - \\
\hline Barium & $43 / 43$ & $16-46$ & 29 & 5 \\
\hline Beryllium & $5 / 43$ & $0.17-0.68$ & 0.34 & 0.21 \\
\hline Cadmium & $2 / 43$ & $3.5-4.3$ & 3.9 & - \\
\hline Calcium & $43 / 43$ & $16,000-44,000$ & 21,000 & 5500 \\
\hline Chromium & $5 / 43$ & $5.7-18$ & 11 & 5 \\
\hline Cobalt & $2 / 43$ & $7.5-7.6$ & 7.5 & - \\
\hline Copper & $40 / 43$ & $2.9-13$ & 6.8 & 2.3 \\
\hline Iron & $37 / 43$ & $8.7-170$ & 36 & 29 \\
\hline Lead & $21 / 39$ & $0.6-15$ & 2.1 & 3.1 \\
\hline Magnesium & $43 / 43$ & $3600-9300$ & 4800 & 1100 \\
\hline Manganese & $29 / 43$ & $0.89-7.1$ & 1.5 & 1.2 \\
\hline Mercury & $8 / 39$ & $0.052-0.46$ & 0.15 & 0.13 \\
\hline Nickel & $2 / 43$ & $13-16$ & 15 & - \\
\hline Potassium & $28 / 43$ & $860-2900$ & 1400 & 480 \\
\hline Selenium & $8 / 43$ & $0.66-2.3$ & 1.1 & 0.60 \\
\hline Silicon & $1 / 1$ & - & 2800 & - \\
\hline Sodium & $43 / 43$ & $2300-11,000$ & 3400 & 1800 \\
\hline Strontium & $2 / 2$ & $92-100$ & 96 & - \\
\hline Thallium & $7 / 39$ & $0.62-1.6$ & 0.85 & 0.37 \\
\hline Tin & $4 / 43$ & $26-82$ & 46 & 25 \\
\hline Vanadium & $2 / 43$ & $3.3-3.5$ & 3.4 & - \\
\hline Zinc & $43 / 43$ & $11-120$ & 29 & 18 \\
\hline \multicolumn{5}{|c|}{ Volatile Organic Compounds } \\
\hline $\begin{array}{l}\text { 1,1,1- } \\
\text { Trichloroethane }\end{array}$ & $3 / 62$ & $1.2-2.6$ & 1.8 & 0.7 \\
\hline 2-Butanone & $1 / 62$ & - & 26 & - \\
\hline Acetone & $5 / 62$ & $8.8-43$ & 26 & 13 \\
\hline Acetonitrile & $1 / 27$ & - & 170 & - \\
\hline $\begin{array}{l}\text { Bromodichloromet } \\
\text { hane }\end{array}$ & $25 / 36$ & $0.7-3.3$ & 1.6 & 0.7 \\
\hline
\end{tabular}




\begin{tabular}{|c|c|c|c|c|}
\hline \multirow[t]{2}{*}{ Constituent } & \multirow[t]{2}{*}{ Frequency $^{\top}$} & \multicolumn{3}{|c|}{ Concentration $(\mu \mathrm{g} / \mathrm{L})^{2}$} \\
\hline & & Range & Average & $\begin{array}{l}\text { Standard } \\
\text { Deviation }^{3}\end{array}$ \\
\hline Bromoform & $1 / 36$ & - & 0.5 & - \\
\hline Chloroform & $62 / 62$ & $6.9-32$ & 19 & 6.6 \\
\hline $\begin{array}{l}\text { Dibromochloromet } \\
\text { hane }\end{array}$ & $3 / 36$ & $1.4-2.0$ & 1.8 & 0.3 \\
\hline Ethylbenzene & $4 / 36$ & $0.5-4.9$ & 1.7 & 2.1 \\
\hline Hexone & $6 / 62$ & $1.4-110$ & 37 & 41 \\
\hline Methylene chloride & $40 / 62$ & $0.4-1.6$ & 1.1 & 0.4 \\
\hline Tetrahydrofuran & $1 / 62$ & - & 36 & - \\
\hline Toluene & $2 / 62$ & $0.14-0.18$ & 0.16 & - \\
\hline \multirow[t]{2}{*}{ Xylenes (total) } & $8 / 62$ & $0.48-12$ & 4.8 & 4.6 \\
\hline & \multicolumn{4}{|c|}{ Semivolatile Organic Compounds (Acids/Bases/Neutrals) } \\
\hline \multirow{2}{*}{$\begin{array}{l}\text { Di-n-butylphthalate } \\
\text { Phenol }\end{array}$} & $2 / 14$ & $2.5-2.6$ & 2.5 & - \\
\hline & $1 / 43$ & - & 1.8 & - \\
\hline \multicolumn{5}{|c|}{ logical Param } \\
\hline \multirow{2}{*}{$\begin{array}{l}\text { Gross Alpha } \\
\text { Gross beta }\end{array}$} & $8 / 43$ & $0.87-2.9$ & 1.7 & 0.26 \\
\hline & $11 / 43$ & $2.1-4.3$ & 3.2 & 0.2 \\
\hline \multicolumn{5}{|c|}{$\begin{array}{l}\text { Number of samples with detectable concentrations/total number of samples analyzed. } \\
2 \text { Conductivity units are } \mu \text { mhos } / \mathrm{cm} \text { and radiological parameters are } \mathrm{pCi} / \mathrm{L} \text {. } \\
3 \text { Two times the standard error of the mean for radiological parameters. }\end{array}$} \\
\hline
\end{tabular}

\section{A.2.7 323 Building}

Mission and Activities: Work in the 323 Building includes research into the development and characterization of structural materials. The activities conducted in this building are in support of the mechanical property (tensile and compression) testing mission for both radioactive and non-radioactive material as well as autoclave testing for high temperature corrosion and stress corrosion studies. Tests are conducted in a small hot cell. Tested materials are solid form and contain activation products resulting from irradiation in a reactor.

Physical Description: The 323 Building is a one-story, rectangular shaped, metal frame structure built on a concrete foundation and floor slab. The roof is pitched, and the exterior of the building is made of insulated metal siding. The building has about 4,200 square feet of floor space. Exhaust air is HEPA filtered and sampled for radioactive particles before being emitted from the building. Figure A. 8 is a simplified drawing of the ventilation and air-emission sampling systems. Sampling system configuration drawings have been developed and are maintained in PNNL's Essential Drawings System. The building is serviced by the 300 Area SNS and PS and is not equipped with any liquid effluent sampling or monitoring systems.

Radiological Inventory: Curie quantities of radioactive materials in solid form are stored and tested in the 323 hot cell. The 1997 PTE for the building was $1.7 \mathrm{E}-4 \mathrm{mrem} / \mathrm{yr}$, see Table A.2.

Chemical Inventory: A variety of types and forms of chemicals are used in the building.

Emission History: Radioactive air emissions have been and continue to be measured. Radionuclide air emission data since 1991 are shown in Table 3.1. 


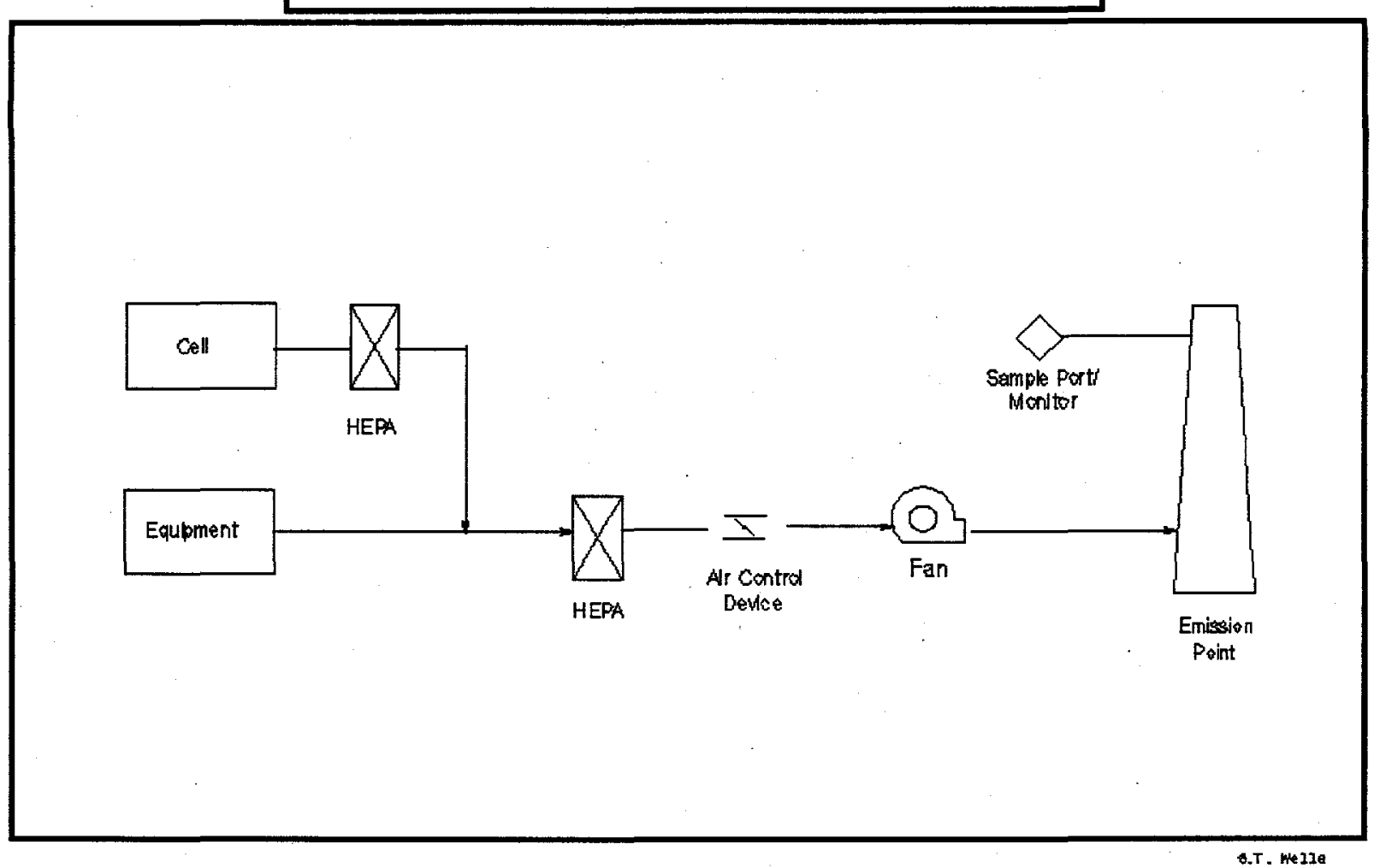

Figure A.8 323 Simplified Ventilation System Drawing

\section{A.2.8 326 Building}

Mission and Activities: The building is used to conduct mechanical testing of metallic and ceramic composite materials, specimen preparation for optical/electron beam microscopes and the subsequent examination/characterization of these specimens, and the preparation of specimens for $X$-ray diffraction (XRD) analysis. Sample preparation activities include sample receiving and sample-size reduction (cutting, grinding, punching, breaking, electropolishing, and ion micromilling). In addition, analytical characterization of samples from radioactive waste tank is performed.

Physical Description: The building has two-stories and a basement. The framework is bolted-steel and exterior walls are fluted steel insulted panels. Floors are reinforced concrete finished with vinyl asbestos tile with access trenches for utility distribution under the main floor. The building has about 63,000 square feet of floor space and is equipped with glove boxes, fume hoods, and hot cells. Exhaust air is HEPA filtered and sampled for radioactive particles before exiting through a single emission point from the building. Figure A.9 is a simplified drawing of the ventilation and air emission sampling systems.

Ventilation and sampling system configuration drawings have been developed and are maintained in PNNL's Essential Drawings System.

The building is served by the 300 Area PS, retention process sewer (RPS) and SNS. The SNS serves the restrooms and lunchrooms, the PS serves process areas, and the RPS serves process areas with a greater potential to discharge radioactive materials. EM has a list of PS and RPS access points. In addition, as built drawings of the building's liquid effluent systems have been developed and are maintained in PNNL's Essential Drawings System. The building is equipped with a liquid-effluent sampling system on the PS and RPS that includes the capability for continuously monitoring $\mathrm{pH}$, conductivity, and flow, as well as the capability for obtaining flow-composite samples. 
Radiological Inventory: Radioactive material is primarily from samples that may be in the form of solid, powder, fragments, and monoliths. The materials include solid samples containing activation products resulting from irradiation in reactors and spent fuel powders/fragments. A wide range of radionuclides may be present. The 1997 PTE for the building was $3.9 \mathrm{E}-5 \mathrm{mrem} / \mathrm{yr}$, see Table A.2.

Chemical Inventory: A variety of types and forms of chemicals are used in the building.

Emission History: Radioactive air emissions have been and continue to be measured. Radionuclide air emission data since 1991 are shown in Table 3.1.

This building is equipped with liquid effluent sampling systems for both the PS and RPS and was sampled during the sampling campaign conducted by PNNL EM in 1994 and 1995 (Thompson et al. 1997). No continued liquid effluent sampling is required for this facility. Tables A.5 and A.6 provide a summary of the results of the sampling campaign. These results show low concentrations (ppb) of pollutants, generally less than the sewer system waste acceptance criteria.

\section{FACILITY: $\quad 300$ Area}

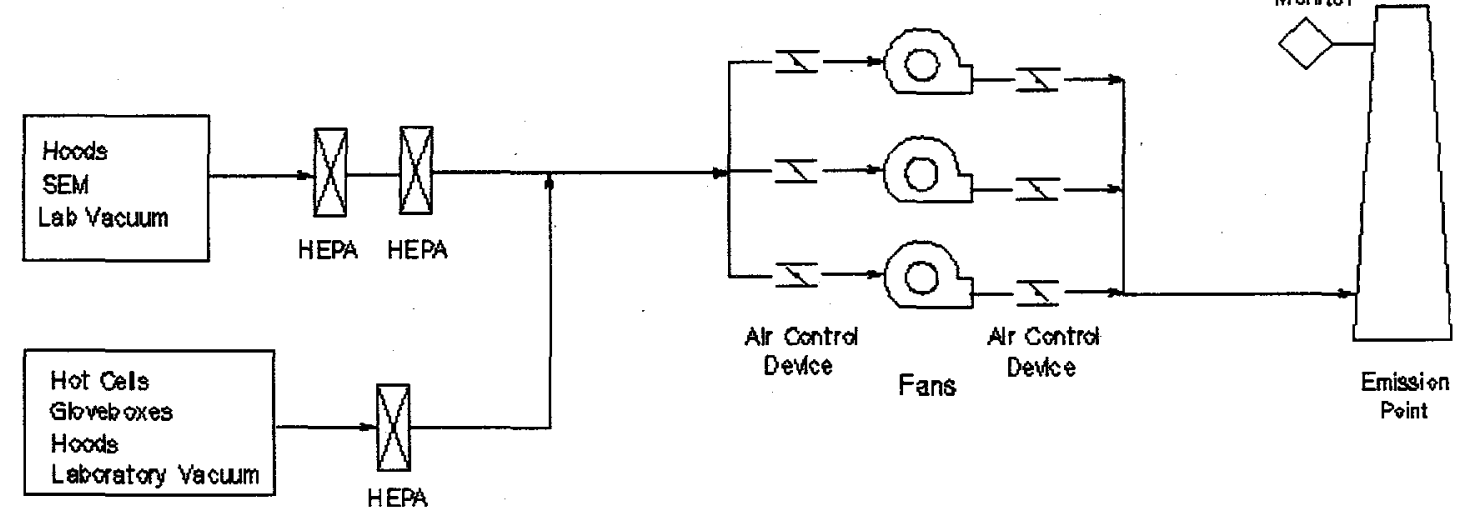

Figure A.9 326 Simplified Ventilation System Drawing 
Table A.5 Constituents Detected in Building 326 PS Samples

\begin{tabular}{|c|c|c|c|c|}
\hline \multirow[t]{2}{*}{ Constituent } & \multirow[t]{2}{*}{ Frequency $^{\top}$} & \multicolumn{3}{|c|}{ Concentration $(\mu \mathrm{g} / \mathrm{L})^{2}$} \\
\hline & & Range & Average & $\begin{array}{l}\text { Standard } \\
\text { Deviation }^{3}\end{array}$ \\
\hline \multicolumn{5}{|c|}{ General Chemical Parameters } \\
\hline Alkalinity & $13 / 13$ & $20,000-130,000$ & 71,000 & 33,000 \\
\hline $\begin{array}{l}\text { Chemical Oxygen } \\
\text { Demand }\end{array}$ & $12 / 13$ & $4000-360,000$ & 50,000 & 100,000 \\
\hline Conductivity & $23 / 23$ & $98-350$ & 200 & 71 \\
\hline $\mathrm{PH}$ & $23 / 23$ & $1.8-8.9$ & 7.3 & 1.5 \\
\hline Total carbon & $13 / 13$ & $13,000-120,000$ & 31,000 & 29,000 \\
\hline $\begin{array}{l}\text { Total dissolved } \\
\text { solids }\end{array}$ & $13 / 13$ & $80,000-210,000$ & 130,000 & 49,000 \\
\hline $\begin{array}{l}\text { Total organic } \\
\text { carbon }\end{array}$ & $20 / 20$ & $2000-110,000$ & 11,000 & 24,000 \\
\hline \multicolumn{5}{|c|}{ Ammonia and Anions } \\
\hline Ammonia & $14 / 24$ & $40-500$ & 190 & 140 \\
\hline Chloride & $21 / 21$ & $2900-85,000$ & 9500 & 17,000 \\
\hline Fluoride & $21 / 21$ & $270-600$ & 400 & 98 \\
\hline Nitrate & $21 / 21$ & $400-12,000$ & 3500 & 3600 \\
\hline Nitrite & $3 / 12$ & - & 200 & - \\
\hline Phosphate & $1 / 21$ & - & 1100 & - \\
\hline Sulfate & $21 / 21$ & $13,000-53,000$ & 23,000 & 12,000 \\
\hline Sulfides & $3 / 13$ & $220-400$ & 300 & 90 \\
\hline \multicolumn{5}{|c|}{ Metals } \\
\hline Aluminum & $19 / 24$ & $29-180$ & 64 & 38 \\
\hline Barium & $24 / 24$ & $21-100$ & 33 & 17 \\
\hline Beryllium & $4 / 24$ & $0.19-0.26$ & 0.21 & 0.03 \\
\hline Cadmium & $6 / 24$ & $1-14$ & 4.2 & 5.0 \\
\hline Calcium & $24 / 24$ & $14,000-43,000$ & 24,000 & 8,000 \\
\hline Chromium & $8 / 24$ & $3.7-7.7$ & 5.5 & 1.3 \\
\hline Cobalt & $1 / 24$ & - & 8.4 & - \\
\hline Copper & $24 / 24$ & $31-1400$ & 160 & 300 \\
\hline Iron & $24 / 24$ & $23-6000$ & 480 & 1200 \\
\hline Lead & $14 / 20$ & $1.5-8.6$ & 3.4 & 2.3 \\
\hline Magnesium & $24 / 24$ & $2400-9100$ & 5100 & 1600 \\
\hline Manganese & $24 / 24$ & $2.2-1500$ & 96 & 300 \\
\hline Mercury & $5 / 20$ & $0.026-0.23$ & 0.11 & 0.075 \\
\hline Nickel & $5 / 24$ & $14-340$ & 89 & 140 \\
\hline Potassium & $22 / 24$ & $840-3900$ & 1700 & 910 \\
\hline Selenium & $3 / 24$ & $0.73-1.2$ & 1.0 & 0.27 \\
\hline Silicon & $3 / 23$ & $2200-2600$ & 2500 & 230 \\
\hline Sodium & $24 / 24$ & $2600-24,000$ & 6500 & 5100 \\
\hline Strontium & $5 / 5$ & $90-100$ & 94 & 5 \\
\hline Thallium & $5 / 20$ & $0.93-2.9$ & 1.5 & 0.80 \\
\hline Tin & $2 / 24$ & $34-49$ & 42 & - \\
\hline Vanadium & $6 / 24$ & $2-4$ & 2.5 & 0.8 \\
\hline Zinc & $24 / 24$ & $48-6100$ & 470 & 1300 \\
\hline \multicolumn{5}{|c|}{ Volatile Organic Compounds } \\
\hline 2-Butanone & $1 / 22$ & - & 48 & - \\
\hline Acetone & $20 / 22$ & $5.5-2500$ & 280 & 560 \\
\hline Chloroform & $19 / 22$ & $0.6-4.3$ & 1.7 & 0.9 \\
\hline Hexone & $2 / 22$ & $1.7-2.0$ & 1.9 & - \\
\hline Isopropyl alcohol & $1 / 22$ & - & 41,000 & - \\
\hline $\begin{array}{l}\text { Methylene } \\
\text { Chloride }\end{array}$ & $2 / 22$ & - & 1.2 & - \\
\hline
\end{tabular}




\begin{tabular}{|c|c|c|c|c|}
\hline \multirow[t]{2}{*}{ Constituent } & \multirow[t]{2}{*}{ Frequency $^{\top}$} & \multicolumn{3}{|c|}{ Concentration $(\mu \mathrm{g} / \mathrm{L})^{2}$} \\
\hline & & Range & Average & $\begin{array}{l}\text { Standard } \\
\text { Deviation }^{3}\end{array}$ \\
\hline Tetrachloroethene & $1 / 22$ & - & 0.51 & - \\
\hline Tetrahydrofuran & $17 / 22$ & $2.8-22$ & 10.4 & 6.5 \\
\hline Trichloroethene & $3 / 22$ & $0.95-5.9$ & 2.9 & 2.6 \\
\hline \multicolumn{5}{|c|}{ Semivolatile Organic Compounds (Acids/Bases/Neutrals) } \\
\hline $\begin{array}{l}\text { Bis(2-ethylhexyl) } \\
\text { phthalate }\end{array}$ & $2 / 24$ & $0.88-1.7$ & 1.29 & - \\
\hline Di-n-octylphthalate & $1 / 6$ & - & 1.3 & - \\
\hline Diethylphthalate & $1 / 6$ & - & 6.6 & - \\
\hline Phenol & $4 / 24$ & $0.83-3.7$ & 1.8 & 1.3 \\
\hline \multicolumn{5}{|c|}{ Semivolatile Organic Compounds (Pesticides) } \\
\hline Aldrin & $1 / 9$ & - & 0.0041 & - \\
\hline Alpha-BHC & $2 / 9$ & $0.0011-0.0025$ & 0.0018 & - \\
\hline Delta-BHC & $1 / 9$ & - & 0.0041 & - \\
\hline \multicolumn{5}{|c|}{ Radiological Parameters } \\
\hline Gross Alpha & $3 / 24$ & $1.2-1.7$ & 1.4 & 0.14 \\
\hline Gross beta & $8 / 24$ & $2.4-7.9$ & 5.0 & 0.73 \\
\hline Tritium & $7 / 24$ & $250-560$ & 380 & 38 \\
\hline $\begin{array}{ll}1 & \text { Number of sar } \\
2 & \text { Conductivity u } \\
3 & \text { Two times the }\end{array}$ & $\begin{array}{l}\text { with detectab } \\
\text { e } \mu \text { mhos/cm } \\
\text { ard error of th }\end{array}$ & $\begin{array}{l}\text { centrations/total } n \\
\text { diological parame } \\
\text { an for radiological }\end{array}$ & $\begin{array}{l}\text { ff samples an } \\
\text { pCi/L. } \\
\text { ters. }\end{array}$ & \\
\hline
\end{tabular}

Table A.6 Constituents Detected in Building 326 RPS Samples

\begin{tabular}{|c|c|c|c|c|}
\hline \multirow[t]{2}{*}{ Constituent } & \multirow[t]{2}{*}{ Frequency } & \multicolumn{3}{|c|}{ Concentration $(\mu \mathrm{g} / \mathrm{L})^{2}$} \\
\hline & & Range & Average & $\begin{array}{l}\text { Standard } \\
\text { Deviation }\end{array}$ \\
\hline \multicolumn{5}{|c|}{ General Chemical Parameters } \\
\hline Conductivity & $2 / 2$ & $191-200$ & 200 & - \\
\hline $\mathrm{PH}$ & $2 / 2$ & $7.7-8$ & 7.9 & - \\
\hline $\begin{array}{l}\text { Total organic } \\
\text { carbon }\end{array}$ & $2 / 2$ & $3000-20,000$ & 12,000 & - \\
\hline \multicolumn{5}{|c|}{ Ammonia and Anions } \\
\hline Ammonia & $1 / 2$ & - & 40 & - \\
\hline Bromide & $1 / 2$ & - & 40 & - \\
\hline Chloride & $2 / 2$ & $3100-3800$ & 3500 & - \\
\hline Fluoride & $2 / 2$ & $300-500$ & 400 & - \\
\hline Nitrate & $2 / 2$ & $390-400$ & 400 & - \\
\hline Phosphate & $1 / 2$ & - & 700 & - \\
\hline Sulfate & $2 / 2$ & $14,000-20,000$ & 17,000 & - \\
\hline \multicolumn{5}{|c|}{ Metals } \\
\hline Aluminum & $1 / 2$ & - & 120 & - \\
\hline Barium & $2 / 2$ & $20-27$ & 24 & - \\
\hline Boron & $1 / 2$ & - & 210 & - \\
\hline Cadmium & $1 / 2$ & - & 4.9 & - \\
\hline Calcium & $2 / 2$ & $20,000-21,000$ & 21,000 & - \\
\hline Copper & $2 / 2$ & $32-72$ & 52 & - \\
\hline Iron & $2 / 2$ & $270-290$ & 280 & - \\
\hline Lead & $2 / 2$ & $1.8-2.0$ & 1.9 & - \\
\hline Magnesium & $2 / 2$ & - & 4500 & - \\
\hline Manganese & $2 / 2$ & $20-29$ & 25 & - \\
\hline Mercury & $2 / 2$ & $0.043-1.3$ & 0.67 & - \\
\hline Nickel & $1 / 2$ & - & 15 & - \\
\hline Potassium & $2 / 2$ & $700-940$ & 820 & - \\
\hline
\end{tabular}




\begin{tabular}{|c|c|c|c|c|}
\hline \multirow[t]{2}{*}{ Constituent } & \multirow[t]{2}{*}{ Frequency } & \multicolumn{3}{|c|}{ Concentration $(\mu \mathrm{g} / \mathrm{L})^{2}$} \\
\hline & & Range & Average & $\begin{array}{l}\text { Standard } \\
\text { Deviation }\end{array}$ \\
\hline Silicon & $2 / 2$ & $2200-2400$ & 2300 & - \\
\hline Silver & $1 / 2$ & - & 56 & - \\
\hline Sodium & $2 / 2$ & $3800-11,000$ & 7400 & - \\
\hline Strontium & $2 / 2$ & $95-97$ & 96 & - \\
\hline Tin & $1 / 2$ & - & 36 & - \\
\hline \multirow[t]{2}{*}{ Zinc } & $2 / 2$ & $250-440$ & 350 & - \\
\hline & & e Organic Comp & & \\
\hline Acetone & $2 / 2$ & $7.1-9.9$ & 8.5 & - \\
\hline Chloroform & $2 / 2$ & $1.3-2$ & 1.6 & - \\
\hline Ethanol & $1 / 2$ & - & 54 & - \\
\hline \multirow[t]{2}{*}{ Trichloroethene } & $2 / 2$ & $0.94-1.3$ & 1.1 & - \\
\hline & Semivolatile C & Compounds (A & es/Neutrals & \\
\hline $\begin{array}{l}\text { Bis(2-ethylhexyl) } \\
\text { phthalate }\end{array}$ & $2 / 2$ & $1.4-2.0$ & 1.7 & - \\
\hline Diethylphthalate & $1 / 2$ & - & 0.81 & - \\
\hline \multicolumn{5}{|c|}{$\begin{array}{l}\text { Number of samples with detectable concentrations/total number of samples analyzed. } \\
2 \text { Conductivity units are } \mu \mathrm{mhos} / \mathrm{cm} \text { and radiological parameters are pCi/L. } \\
3 \text { Two times the standard error of the mean for radiological parameters. }\end{array}$} \\
\hline
\end{tabular}

\section{A.2.9 329 Building}

Mission and Activities: This building conducts measurements and procedure development in support of the Hanford Site environmental restoration and waste management activities. Environmental samples, including soils, vegetation, water, decommissioning materials, and samples of high-level tank waste are analyzed for all radionuclides and hazardous constituents. Advanced analytical procedures are also developed, tested, and applied.

The building also conducts R\&D activities in the nuclear sciences, particularly in the areas of radiation instrumentation development and applications, low-level radioactive waste characterization and management, radiological decommissioning, environmental radioactivity measurements, radiochemical separations and measurements, and basic nuclear chemistry and physics.

Physical Description: The 329 Chemical Science Laboratory has about 40,000 square feet of floor space on two floors. The building has general electronics, low-level radiochemistry, analytical chemistry laboratory space; a neutron multiplier (currently out of service and being dismantled); and associated offices and storage space on the first floor. The second floor is primarily mechanical and electrical rooms. Exhaust air is HEPA filtered and sampled for radioactive airborne particles before exiting the building at a single emission point. Figure A.10 is a simplified drawing of the ventilation and air emission sampling systems. Ventilation and sampling system configuration drawings have been developed and are maintained in PNNL's Essential Drawings System.

The building is served by the 300 Area PS, RPS, and SNS. The SNS serves the restrooms and lunch rooms and is also tied into one corridor of the building (C-section), the RPS serves process areas in the other two corridors (A-and B- sections). Effluent Management has a list of each of the sewer access points. In addition, as-built drawings of the building's liquid effluent systems have been developed and are maintained in PNNL's Essential Drawings System. The building is equipped with a liquid effluent sampling system on the RPS that includes capability for continuously monitoring $\mathrm{pH}$, conductivity, and flow, as well as the capability for obtaining flow-composite samples. 


\section{FACILITY: $\quad 300$ Area}

EMISSION POINT:

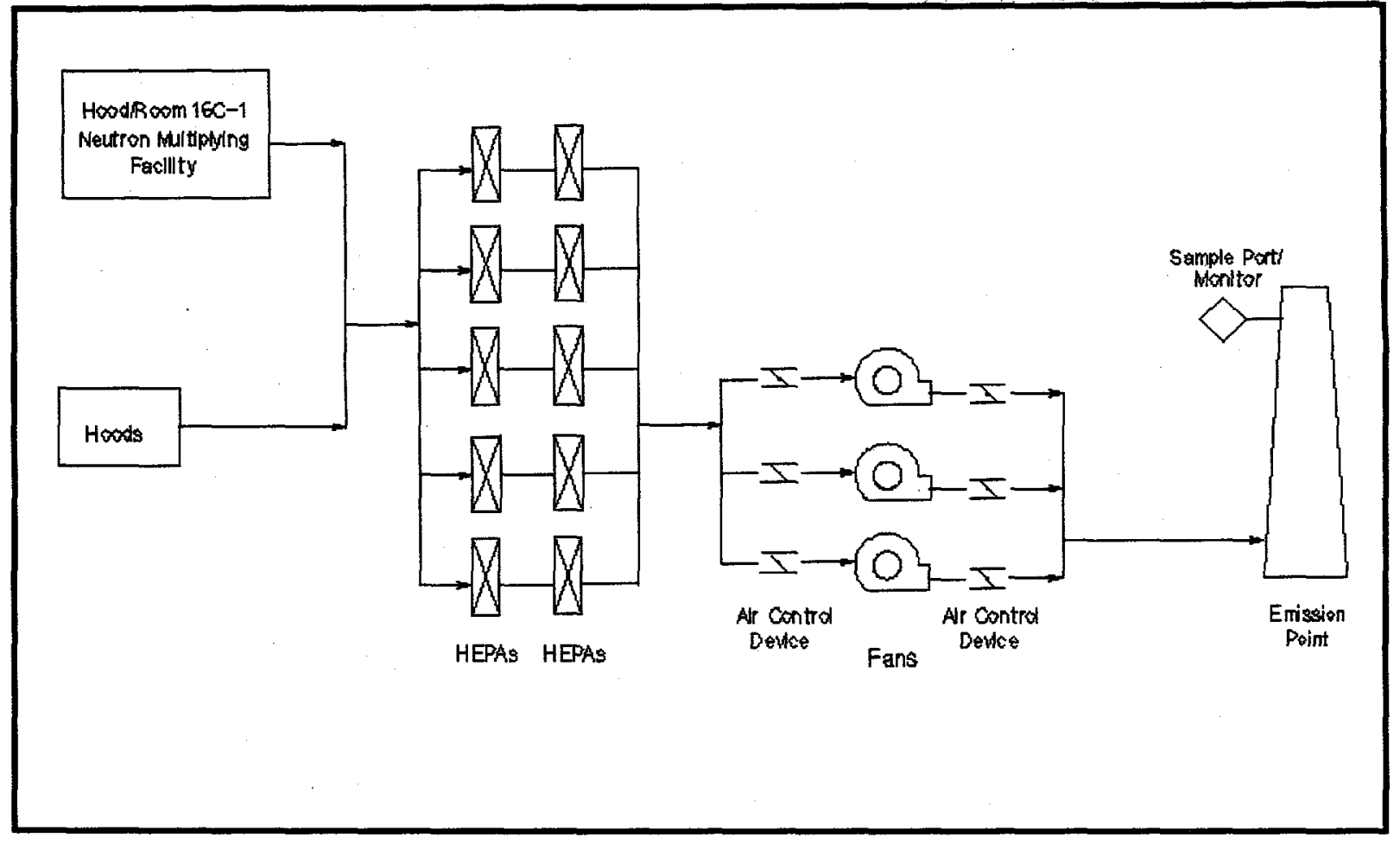

Figure A.10 329 Simplified Ventilation System Drawing

Radiological Inventory: A variety of radionuclides may be present in the building. Inventories are generally in small quantities (micro-curie to milli-curie) and can be in solid, liquid, powder, or sealed source forms. In addition, larger quantities ( $\mathrm{kg}$ or greater) of uranium and thorium may be present as fuel rods or pellets, or powder. Some plutonium may also be present. The 1997 PTE for the building was 3.5E-3 mrem/yr, see Table A.2.

Chemical Inventory: A variety of types and forms of chemicals are used in the building.

Emission History: Radioactive air emissions have been and continue to be measured. Radionuclide air emission data since 1991 are shown in Table 3.1.

This building is equipped with liquid effluent sampling and monitoring ( $\mathrm{pH}$, conductivity, and flow) systems for the retention process sewer, but was not sampled during the sampling campaign conducted by PNNL EM in 1994 and 1995 (Thompson et al. 1997). The 329 Building was undergoing extensive remodeling during the campaign, and no R\&D work was being conducted in the RPS wings.

\section{A.2.10 332 Building}

Mission and Activities: The 332 Building is a one-room packaging and testing facility utilized by PNNL's Environmental Management Services Department to determine if prototype packaging can pass prescribed U.S. Department of Transportation (USDOT) test requirements.

Physical Description: The building is an insulated metal building on concrete footings and a slab. It is a one-room building with about 400 square feet of floor space. No water supply or sewer systems are provided in the building, although the building has a drain connected to a sump that can be manually 
pumped out. The ventilation system is a fume hood exhaust that is manually controlled. The building has no effluent sampling or monitoring systems.

Radiological Inventory: None. Radiological materials are not permitted within this facility.

Chemical Inventory: Very few, if any, chemicals are present in the building. The only chemicals are those used to fill packages when testing (water, inert materials).

Emission History: N/A. No monitoring or sampling of facility effluents has been required, and no historic data exist.

\section{A.2.11 336 Building}

Mission and Activities: The primary mission of the building is the engineering and analysis of multiphase flow experiments. Near-term objectives support model development and code assessment activities to continue involvement in basic research related to multiphase flow phenomena, and to experimentally address issues related to Hanford waste retrieval, transport, and disposal. Activities of the Fluid Dynamics Laboratory include bubble dynamics experiments, slurry transport/resuspension studies, and waste tank mixing/mitigation/retrieval experiments using a variety of non-radioactive physical simulants. Major building equipment/systems include the 1/4- and 1/12-scale waste tank models, a scaled waste retrieval/pneumatic conveyance test facility, and numerous other semi-permanent to temporary test articles and facilities.

Work activities conducted by research staff include the development and assessment of waste retrieval and transport technologies. A multi-scale tanks system (1/4,1/12, and 1/25 scale of Double Shell Tanks) and ancillary equipment are used to accommodate the full-technology development cycle for retrieval technologies such as pulsed-air, pneumatic conveyance, and extendable nozzle. Additional studies are performed to enhance or better understand existing technologies such as aerosol generation during sluicing and performance correlations for mixer pumps. A 3-in. slurry test loop is used to test the performance of candidate instruments for monitoring slurry transport through pipes. An adjacent simulant development and measurements laboratory supports the high-bay testing and houses state-of-the-art instruments that provide a wide range of physical properties important to waste retrieval and transport.

Physical Description: The 336 High-Bay Testing Facility provides staff with a three-story-high bay and a 20 -foot-diameter circular pit, approximately 50 -feet deep. The approximately 4,000 square feet building houses a series of tanks up to about a 25,000 -gallon capacity. The southwest corner of the building provides two supporting laboratories.

The ventilation system has a nominal capacity of ten air changes per hour. The building is not equipped with exhaust air filtration or sampling systems.

The building is served by the 300 Area PS and SNS; the SNS serves the restrooms, and the PS serves process areas. Effluent Management has a list of PS access points. The building does not have a liquid effluent sampling system.

Radiological Inventory: None. Radiological materials are not permitted within this facility.

Chemical Inventory: A variety of types and forms of chemicals are used in the building.

Emission History: N/A. No monitoring or sampling of facility effluents has been required, and no historic data exist.

\section{A.2.12 338 Building}

Mission and Activities: The principal effort in the building is focused on assembling and testing equipment to be used by the DOE client. The work is all with non-radioactive materials. A portable X-ray machine may be used. A second project is being conducted in the 338 Building high bay using the Variable Geometry truss robot. 
The 338 Building houses materials processing laboratories that consist of several metals processing capabilities centered around aluminum and light metal development and casting of lightweight materials and advanced metal composites.

The Thermo-mechanical Processing Laboratory consists of a rolling mill, heat treating furnaces, and brake shear.

The second major processing laboratory is the metal-casting laboratory. The laboratory consists of two induction power units, a centrifugal casting unit, meltspin caster, a die casting coatings evaluation unit, and associated equipment for sectioning, mixing, and heat treating cast materials. The drop tower will be used for coining of cast gears and is an element of the casting and processing laboratory.

Physical Description: The building has about 18,000 square feet of floor space on one floor consisting of office, high-bay, and support space. The building also has a large basement area. The exhaust air is not HEPA filtered or sampled before exiting the building, and no air emission filtration or sampling systems are in place.

The building is served by the 300 Area PS and SNS; the SNS serves the restrooms, and the PS serves process areas. Effluent Management has a list of PS access points. The building does not have a liquideffluent sampling system.

Radiological Inventory: None. Radiological materials are not permitted within this facility.

Chemical Inventory: A variety of types and forms of chemicals are used in the building.

Emission History: N/A. No monitoring or sampling of facility effluents has been required, and no historic data exist.

\section{A.2.13 350 Building}

Mission and Activities: The 350 Building is primarily offices and shop areas for PNNL Crafts Services Department.

Physical Description: The building is a single-story structural steel building with about 16,000 square feet of floor space. It contains craft shops, change rooms, restrooms, a lunchroom, and offices. The craft shops have a dust collection system, and the air is fitered before being recirculated into each respective shop. The building is not equipped with HEPA filtration or a sampling system for airborne emissions. The building is served by the 300 Area SNS and does not have a liquid-effluent sampling system.

Radiological Inventory: None. Radiological materials are not permitted within this facility.

Chemical Inventory: A variety of types and forms of chemicals are used in the building.

Emission History: N/A. No monitoring or sampling of facility effluents has been required, and no historic data exist.

\section{A.2.14 350-A Building}

Mission and Activities: The 350-A Building is a paint shop with storage space for paints and similar products and a paint spray booth.

Physical Description: The building has about 1,400 square feet of floor space. No HEPA filter or sampling system exists for airborne emissions. The building is served by the 300 Area SNS and does not have a liquid-effluent sampling system.

Radiological Inventory: None. Radiological materials are not permitted within this facility. 
Chemical Inventory: The chemical inventory consists of paints, solvents, and similar materials.

Emission History: N/A. No monitoring or sampling of facility effluents has been required, and no historic data exist.

\section{A.2.15 350-B Building}

Mission and Activities: The 350-B Building is a small warehouse that houses parts and materials required to perform maintenance.

Physical Description: The building has about 2,100 square feet of floor space for storage. Ventilators are provided to remove excess summer heat, but no filtration or sampling systems exist for airborne emissions. The building is connected to the 300 Area SNS and does not have a liquid effluent sampling system.

Radiological Inventory: None. Radiological materials are not permitted within this facility.

Chemical Inventory: Some flammable/combustible liquids or corrosive liquids may be present in the building.

Emission History: N/A. No monitoring or sampling of facility effluents has been required, and no historic data exist.

\section{A.2.16 350-C Building}

Mission and Activities: The 350-C Building is a small storage building used to store miscellaneous building lumber and carpenter supplies.

Physical Description: The building is a prefabricated metal building on a concrete slab floor with a large roll-up door. It has about 200 square feet of floor space for storage, and does not have ventilation, water, sewer, or sampling capabilities.

Radiological Inventory: None. Radiological materials are not permitted within this facility.

Chemical Inventory: None. Storage of chemicals in the building is not allowed.

Emission History: N/A. No monitoring or sampling of facility effluents has been required, and no historic data exist.

\section{A.2.17 350-D Building}

Mission and Activities: The 350-D Building is a small storage building used to stage used oils and other waste products before ultimate disposal. The building includes a $<90$ day storage area for PCB waste.

Physical Description: The building has about 1,000 square feet of floor space for storage. No filtration or sampling systems exist in the building for airborne emissions. No sewer system connections or liquid effluent sampling systems are provided.

Radiological Inventory: None. Radiological materials are not permitted within this facility.

Chemical Inventory: A variety of types and forms of chemicals are used in the building.

Emission History: N/A. No monitoring or sampling of facility effluents has been required, and no historic data exist. 


\section{A.2.18 3020 Building (EMSL)}

Mission and Activities: The EMSL provides integrated laboratory, computer, and seminar functions and contains basic, multi-disciplinary research programs involving chemical, biological, materials, and computational sciences. Research and development activities are undertaken in EMSL to advance the understanding of molecular sciences and to apply the advanced understanding gained to a broad spectrum of environmental restoration and waste management missions.

Physical Description: The EMSL Building consists of experimental laboratories (dry, wet, \& filtered), theory laboratories, laboratory support offices, conference rooms, computer graphics rooms, administrative support offices, a library, lunch/interaction areas, support/crafts shops, storage, and a seminar area. EMSL has about 200,000 square feet of floor space.

The EMSL experimental laboratories are arranged in five clusters. Each of the five lab clusters has separate once-through ventilation and emissions exhaust systems for chemical hoods. A separate HEPA filtered exhaust system is also provided. The HEPA filtered exhaust system is equipped with a particulate sampling system for measuring radioactive air emissions. All of the five emission points are equipped with ports through which air chemical emissions can be sampled. Figure A.11 is a simplified drawing of the HEPA filtered exhaust and air-emission sampling systems. Ventilation and sampling system configuration drawings have been developed and are maintained in PNNL's Essential Drawings System.

The building is equipped with two sewer systems: a sanitary system that serves restrooms, lunchrooms, and mechanical room areas, and a process system that serves laboratories. The process system discharges to large tanks in a tank pit. The tanks are equipped with sampling and monitoring systems so that process effluent batches can be sampled and measured before discharge. Figure A.12 shows the process collection tanks. Ultimately, liquid effluent from the process tanks discharges to the sanitary sewer, which discharges to the City of Richland Publicly Owned Treatment Works. EMSL has an Industrial Wastewater Permit with the City to govern the discharges of process effluent. As-built drawings of the liquid effiuent distribution and sampling systems have been developed and are maintained in PNNL's Essential Drawings System.

Radiological Inventory: Currently (as of the issuing of this FEMP), EMSL radiological inventory consists of a small number of sealed sources. The 1997 PTE for the building was 0, see Table A.2.

Chemical Inventory: A wide variety of types and forms of chemicals are used in the building.

Emission History: EMSL started up operations in 1997, so little historic data exist. Sampling for radioactive airborne emissions was begun in December of 1997. The measured emissions for December are 9.3E-10 total alpha and 2.0E-9 total beta. However, since no dispersible radioactive material was introduced into the building in 1997, the emitted radioactivity is indicative of background levels (naturally occurring materials and world-wide fallout).

Total organic carbon in air emissions were measured in 1998 in compliance with an NOC and demonstrated that emissions were below the $0.24 \mathrm{lb} / \mathrm{hr}$ permitted emission limit.

Compliance sampling of liquid effluents also began in 1997 after EMSL started operations. These data are reported on monthly Discharge Monitoring Reports to the City of Richland. A summary of the data is provided in Table A.7. 


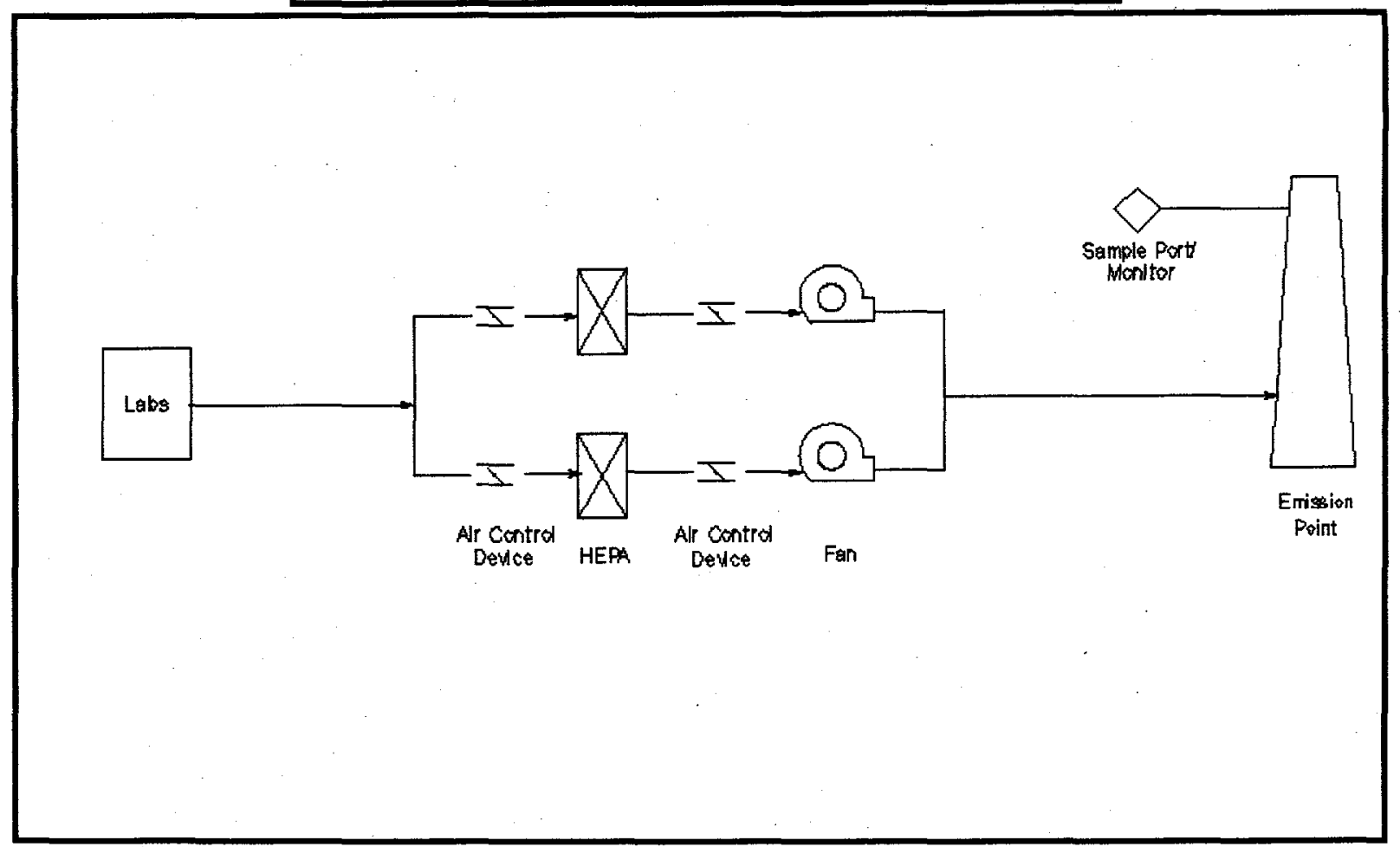

Figure A.11 EMSL Simplified Ventilation System Drawing
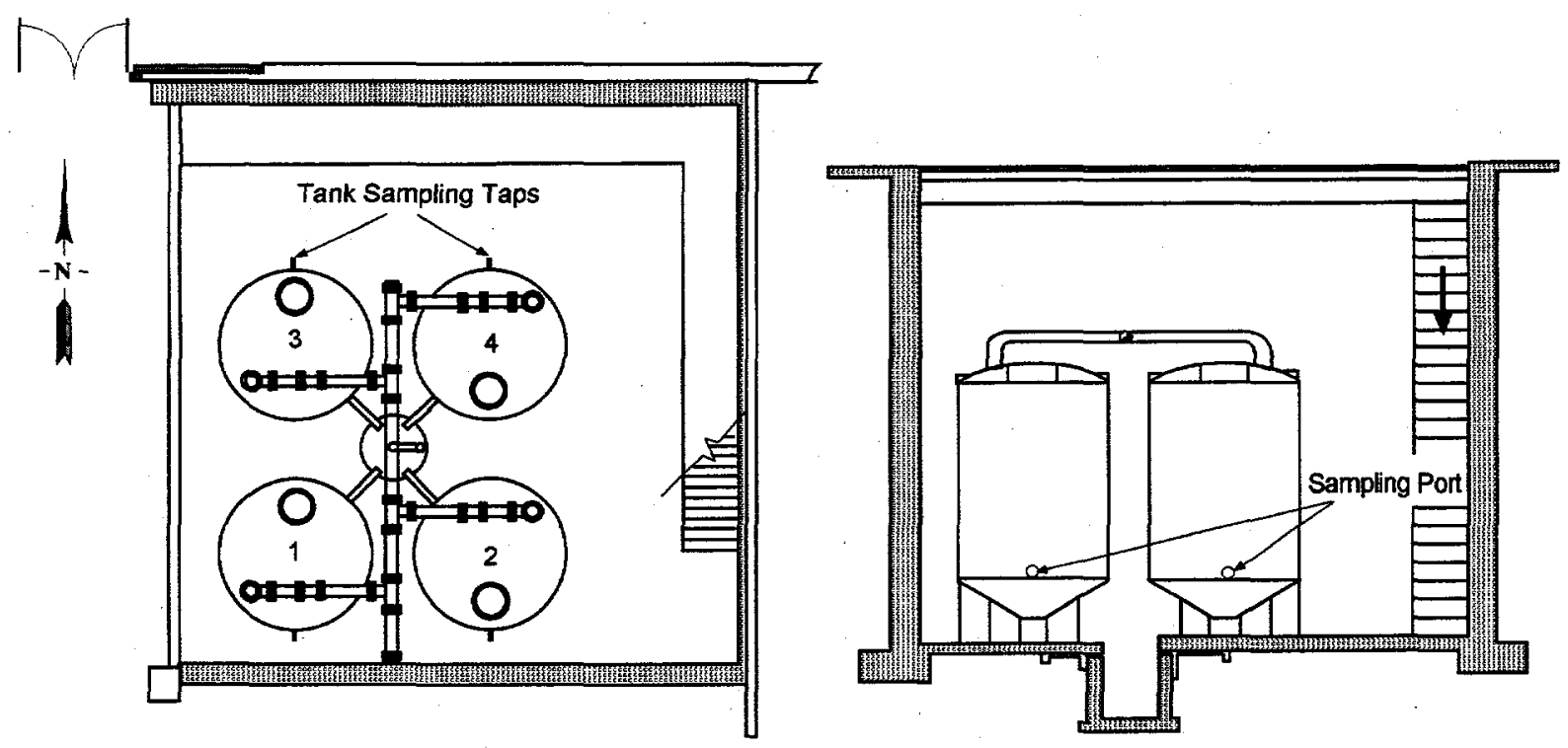

Top View

Side View

980800087.10

Figure A.12 EMSL Process Sewer Tanks

Table A.7 EMSL Liquid Effluent Data 


\begin{tabular}{|l|c|c|}
\hline Constituent & Frequency & Range \\
\hline No. of batches discharged & 30 & \\
\hline PH & $30 / 30$ & $6.2-8.5 \mathrm{pH}$ units \\
\hline Conductivity & $30 / 30$ & $\begin{array}{c}87-648 \\
\text { umho/cm }\end{array}$ \\
\hline BOD & $5 / 6$ & $2-200 \mathrm{ug} / \mathrm{L}$ \\
\hline TSS & $6 / 6$ & $6-35$ \\
\hline Ammonia & $6 / 6$ & $0.043-5.6$ \\
\hline Arsenic & $0 / 5$ & $\mathrm{ND}$ \\
\hline Cadmium & $0 / 5$ & $\mathrm{ND}$ \\
\hline Chromium & $0 / 5$ & $\mathrm{ND}$ \\
\hline Copper & $5 / 5$ & $\mathrm{ND}$ \\
\hline Cyanide & $2 / 5$ & $0.007-0.042$ \\
\hline Lead & $2 / 5$ & $0.01-0.02$ \\
\hline Mercury & $0 / 5$ & $\mathrm{ND}$ \\
\hline Molybdenum & $4 / 5$ & $0.022-0.048$ \\
\hline Nickel & $4 / 5$ & $0.02-0.028$ \\
\hline Selenium & $1 / 5$ & $0.001-0.005$ \\
\hline Silver & $2 / 5$ & 0.013 \\
\hline Zinc & $5 / 5$ & 0.156 \\
\hline Acetone & $1 / 1$ & $54 \mathrm{ug} / \mathrm{L}$ \\
\hline Chloroform & $1 / 1$ & $4.3 \mathrm{ug} / \mathrm{L}$ \\
\hline Bis (2-Ethlyhexyl)phthalate & $1 / 1$ & $2.1 \mathrm{ug} / \mathrm{L}$ \\
\hline
\end{tabular}

\section{A.2.19 3718-A \& B Buildings}

Mission and Activities: As part of PNNL's cost efficiency and recycling effort, it is the responsibility of the Laboratory Equipment Pool to bring in equipment that is unused onsite and store it for reuse. This building also houses staff and supports general property management functions. The majority of the space is used as general storage of equipment for reuse.

Physical Description: This building consists primarily of general warehouse space with some office and shop areas. The 3718-A \& B building is comprised of three separate structures joined together into one building. A total of 9,600 square feet of floor space is provided. All three structures are metal frame and metal covered. It appears that the center structure was added in between the two outside structures. This building has its own independent peaked roof.

No central ventilation system is provided; thus, the building is not equipped with filters or sampling systems for airborne emissions. The building is served by the 300 Area SNS and does not have a liquid effluent sampling system.

Radiological Inventory: Equipment with low levels of contamination may be received. Administrative controls are employed to ensure security and little potential of release. Temporary radioactive material areas may be set up due to receiving equipment with internal radioactive sources. A radiation protection technician is contacted to determine the level and the posting that determine the relevant procedure.

Chemical Inventory: Some toxic chemicals may be in the building, depending on the equipment brought in (e.g., transformers). Maintenance of equipment may generate toxic compounds.

Emission History: N/A. No monitoring or sampling of facility effluents has been required, and no historic data exist.

\section{A.2.20 3718-P Buildings}

Mission and Activities: This building is used as general warehouse space for furniture, filters, and research equipment designated for future use. 
Physical Description: This building consists primarily of general warehouse space with 12,000 square feet of floor space. Heaters are available to prevent freezing of the fire sprinkler system. No filtration or sampling system exists for the building. The building is not equipped with process water or sewer systems.

Radiological Inventory: None. Radiological materials are not permitted within this facility.

Chemical Inventory: The 3718-P Building was not designed for storage of chemicals or hazardous materials. Small quantities of hazardous materials may be present in the building for maintenance or repair purposes.

Emission History: N/A. No monitoring or sampling of facility effluents has been required, and no historic data exist.

\section{A.2.21 3718-S Buildings}

Mission and Activities: This building is used as general warehouse space for R\&D equipment.

Physical Description: This building consists primarily of general warehouse space with $\mathbf{5 6 0}$ square feet of floor space. The building has a heater, but no active ventilation system and no process water or sewer systems. No effluent sampling systems exist for the building.

Radiological Inventory: None. Radiological materials are not permitted within this facility.

Chemical Inventory: The 3718-S Building was not designed for storage of chemicals or hazardous materials. Small quantities of hazardous materials may be present in the building for maintenance or repair purposes.

Emission History: N/A. No monitoring or sampling of facility effluents has been required, and no historic data exist.

\section{A.2.22 3730 Building}

Mission and Activities: The Gamma Irradiation Facility located in the 3730 Building plays an important role in a wide range of programs (e.g., analysis of Hanford waste tank solutions, corrosion and stresscorrosion cracking studies, and the evaluation of various types of probes under irradiated conditions). The effect of gamma radiation on different materials is evaluated. Activities also include measuring the density of materials and the receiving, sorting and shipping of radioactive materials.

Physical Description: The 3730 Building is a one-story concrete block structure of approximately 4,000 square feet and equipped with a hot cell. Exhaust air from the hot cell is HEPA filtered and sampled for radioactive airborne particles before exiting a single emission point. Figure A.13 is a simplified drawing of the ventilation and air emission sampling systems. Sampling system configuration drawings have been developed and are maintained in PNNL's Essential Drawings System.

The building is served by the 300 Area PS and SNS; the SNS serves the restrooms and lunch rooms, and the PS serves process areas. Effluent Management has a list of PS access points. No liquid effluent sampling system exists for the building.

Radiological Inventory: Curie quantities of radioactive materials in solid form are stored and tested in the building. The 1997 PTE for the building was 3.9E-4 mrem/yr, see Table A.2.

Chemical Inventory: A variety of types and forms of chemicals are used in the building.

Emission History: Radioactive air emissions have been and continue to be measured. Radionuclide air emission data since 1991 are shown in Table 3.1. 


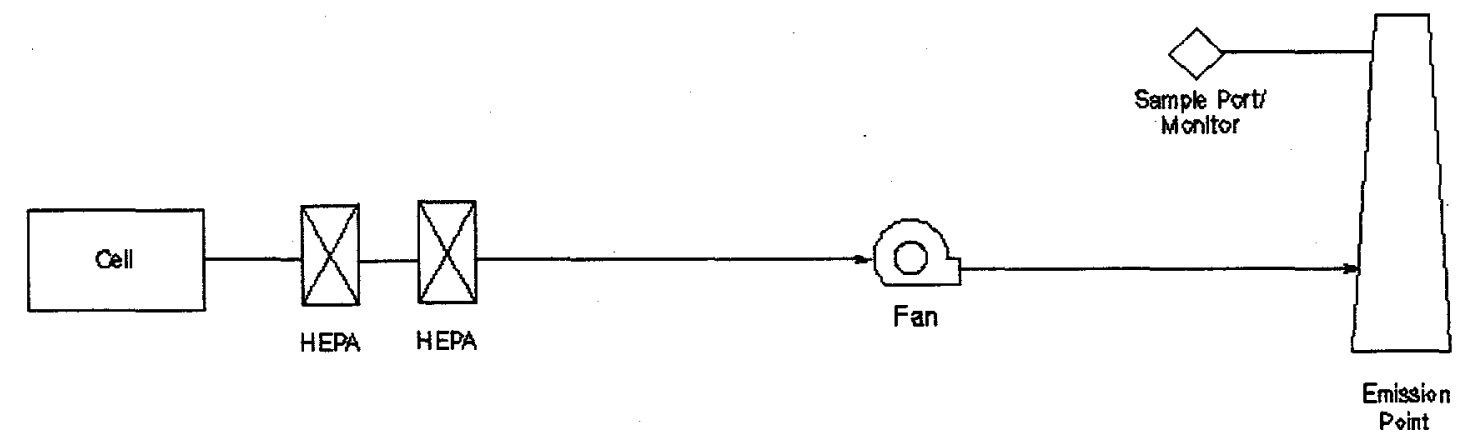

Figure A.13 3730 Simplified Ventilation System Drawing

\section{A.2.23 3745 Building}

Mission and Activities: The primary occupants of the 3745 Building provide electrical and mechanical engineering support for nuclear instrumentation development and instrument fabrication. Other activities are directed at the development and calibration of fiber-optic chemical sensors.

Another mission in the 3745 Building is the operation of a low-level counting lab for radiological control, air sample counting, and smear counting.

Physical Description: The 3745 Building is a two-story wood frame rectangular building with a multiple gable type roof of approximately 5,000 square feet. The main floor is on-grade concrete, and the building is supported on concrete floors. The second floor is wood framing that contains a lunch room and balcony area.

A chemical hood with a HEPA filtered exhaust is used to store more highly contaminated samples. Air emissions from the hood are sampled for radioactive airborne particles. Figure A.14 is a simplified drawing of the ventilation and air emission sampling systems. Sampling system configuration drawings have been developed and are maintained in PNNL's Essential Drawings System.

The building is served by the 300 Area SNS; no liquid effluent monitoring or sampling system is available. 


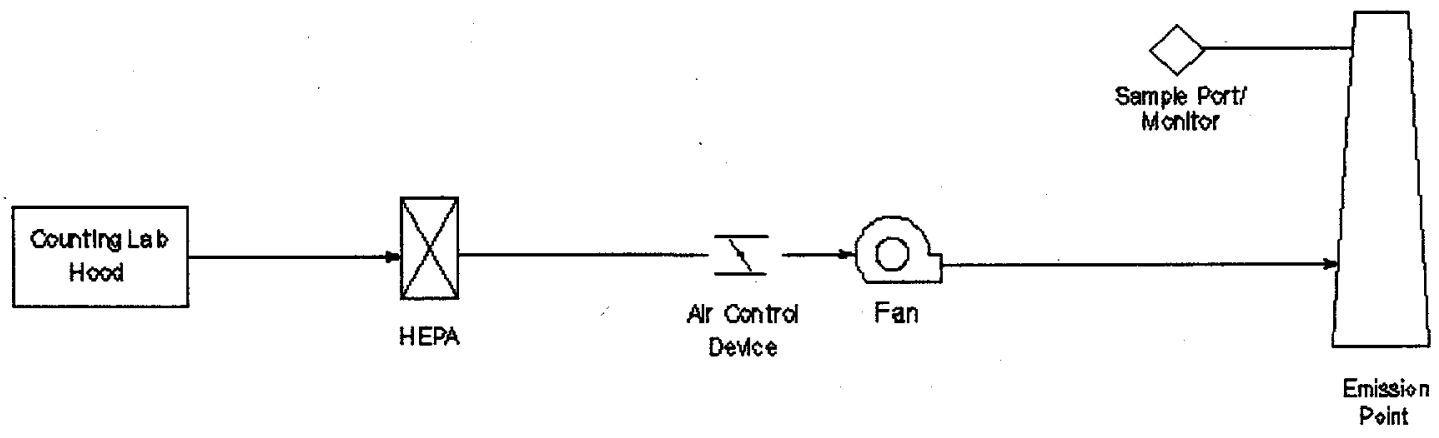

Figure A.14 3745 Simplified Ventilation System Drawing

Radiological Inventory: Low-level air sample and contamination survey samples are stored in the counting laboratory. In addition, the building contains a large number of sealed sources, kilogram quantities of depleted uranium, and gram quantities of transuranics. The 1997 PTE for the building was 5.4E-5 mrem/yr, see Table A.2.

Chemical Inventory: A variety of types and forms of chemicals are used in the building.

Emission History: Radioactive air emissions have been and continue to be measured. Radionuclide air emission data since 1991 are shown in Table 3.1.

\section{A.2.24 622-A}

Mission and Activities: The 622-A Elevator Control Building provides housing and protection for the hoisting equipment and electrical controls for the elevator in the adjacent meteorological tower.

Physical Description: This is a small concrete block building with 170 square feet of floor space. The building is not equipped with a ventilation system, water supply, liquid effluent system, or air or liquid sampling systems.

Radiological Inventory: None. Radiological materials are not permitted within this facility.

Chemical Inventory: Chemicals such as oils and grease may be present to support elevator equipment maintenance and repair.

Emission History: N/A. No monitoring or sampling of facility effluents has been required, and no historic data exist. 


\section{A.2.25 622-B Building}

Mission and Activities: The 622-B Pilot Balloon Release Building provides space to store, inflate, and track weather balloons.

Physical Description: This is a small concrete block building with about 150 square feet of floor space. The building is not equipped with a ventilation system, liquid effluent system, or air or liquid sampling systems.

Radiological Inventory: None. Radiological materials are not permitted within this facility.

Chemical Inventory: This building was not designed for storage of chemicals or hazardous materials. Small quantities may be present for maintenance or repair purposes.

Emission History: N/A. No monitoring or sampling of facility effluents has been required, and no historic data exist.

\section{A.2.26 622-C}

Mission and Activities: The 622-C Building is used for general storage of equipment.

Physical Description: $622-\mathrm{C}$ is a steel storage building with about 1,200 square feet of storage space and a roll-up door. The building is not equipped with ventilation systems, liquid effluent systems, or air or liquid sampling systems.

Radiological Inventory: This storage building does not normally have radioactive materials.

Chemical Inventory: This building was not designed for storage of chemicals or hazardous materials. Small quantities of hazardous materials may be present for maintenance or repair purposes.

Emission History: N/A. No monitoring or sampling of facility effluents has been required, and no historic data exist.

\section{A.2.27 622-R Building}

Mission and Activities: The 622-R space is used to store, prepare, and test equipment that is used for measuring meteorological, air quality, atmospheric radiation, and remote sensing before deployment at various field sites. In addition, the building houses the Hanford Meteorology Station (HMS) which includes weather forecasting and observing; data; collecting, processing, and archiving; and instrument calibration and maintenance. The HMS helps ensure that activities on the Hanford Site that could be severely affected by adverse meteorological conditions can operate in as safe and efficient a manner as possible. In addition, laboratory space is leased to SGN Eurisys Services Group (SESC).

Physical Description: The single story concrete block building has about 9,000 square feet of office and laboratory space. Central ventilation is provided, but the building is not equipped with HEPA filtration or a sampling system for airborne emissions. The building is currently connected to a sanitary sewer system in the 600 Area. No liquid effluent sampling system is provided.

Radiological Inventory: The building contains some sealed sources. The 1997 PTE for the building was 0 , see Table A.2.

Chemical Inventory: Chemicals in the building primarily consist of small quantities of laboratory chemicals.

Emission History: N/A. No monitoring or sampling of facility effluents has been required, and no historic data exist. In the past, a septic tank system was used for sanitary sewer, and this tank is still connected. However, the primary path for liquid effluents is to pump waste to a nearby sanitary sewer system. 


\section{A.2.28 6652-Dome1 Building}

Mission and Activities: The observatory on Rattlesnake Ridge has been used for atmospheric sciences research.

Physical Description: The building has 460 square feet of space. The building has no ventilation or sewer connections and no air or liquid sampling systems.

\section{Radiological Inventory: None.}

Chemical Inventory: This building was not designed for storing chemicals or hazardous materials. Small quantities of hazardous materials may be present for maintenance or repair purposes.

Emission History: N/A. No monitoring or sampling of facility effluents has been required, and no historic data exist.

\section{A.2.29 6652-E Building}

Mission and Activities: The Lysimeter Preparation Building is used for storage in support of lysimeter measurements, although the lysimeter is currently inactive.

Physical Description: The building is a metal structure with about 600 square feet of floor space. The building has no ventilation or sewer connections and no air or liquid sampling systems.

Radiological Inventory: A few sealed sources associated with Lysimeter measuring equipment are stored in the building. The 1997 PTE for the building was 0, see Table A.2.

Chemical Inventory: These buildings were not designed for storing chemicals or hazardous materials. Small quantities of hazardous materials may be present for maintenance or repair purposes.

Emission History: N/A. No monitoring or sampling of facility effluents has been required, and no historic data exist.

\section{A.2.30 6652-L}

Mission and Activities: The Fitzner Eberhardt ALE Bunkers are used for collaborative physics research on gravitational effects. This work will include two complementary experiments: one to discover whether an undiscovered gravity-like force exists, and another to test part of Newton's law of gravitation.

Physical Description: The 6652-L facility is an underground bunker originally used as a Nike missile launch site. It has two large underground areas (approximately 4,000 square feet each) that have been made into labs for the collaborative experiments. The site was selected for the experiments because the bunker was an unused underground structure of adequate size having natural temperature and moisture stability and the site is serviced by electrical power, telephone lines, and an infrequently traveled road (reducing the potential for disturbances).

Radiological Inventory: None. Radiological materials are not permitted within this facility.

Chemical Inventory: Cryogenics only (e.g. nitrogen or helium)

Emission History: N/A. No monitoring or sampling of facility effluents has been required, and no historic data exist. 


\section{A.2.31 747-A and TR1}

Mission and Activities: The 747-A Whole Body Counter is used to provide technical services in internal dosimetry, external dosimetry, instrument calibration, and dosimetry records for 1) protecting the heaith of workers and the public and 2) providing liability protection for government and industrial customers.

Physical Description: The 747-A Building is one-story concrete block building that contains dry laboratory and office space. The adjacent trailer, 747-AT1, contains offices, dry labs, and common space used to support activities conducted within the 747-A Building. The 747-A Building and the adjacent trailer have about 2,000 and 1,600 square feet, respectively. The 747-A Building has a central HVAC system. Neither building is equipped with a filtration or air sampling system. Sanitary sewer hookup is provided to both buildings to support the change room and bathrooms, but the buildings do not have liquid effluent sampling systems.

Radiological Inventory: The 747-A building has a number of sealed sources. The 1997 PTE for the building was 0 , see Table A. 2 .

Chemical Inventory: Chemicals in the 747-A building are limited to small quantities of flammable/combustible or corrosive liquids.

Emission History: N/A. No monitoring or sampling of facility effluents has been required, and no historic data exist.

\section{A.2.32 Lysimeters}

Mission and Activities: The 100, 300, and 600 Area lysimeters are used to study the filtration of contaminants through the soil.

Radiological Inventory: Sealed sources may be used at the lysimeter sites to aid in research measurements.

Chemical Inventory: Chemicals are not stored at the lysimeter sites.

Emission History: N/A. No monitoring or sampling of facility effluents has been required, and no historic data exist.

\section{A.2.33 Environmental Monitoring Stations}

Mission and Activities: Environmental monitoring stations are positioned at strategic locations around the Hanford Site to aid in sample collection to determine the effects of Hanford Site releases on the environment.

Physical Description: The stations consist of small enclosures with 50 to 150 square feet of concrete pad as a foundation. No ventilation, water, or sewer systems are provided.

Radiological Inventory: None.

Chemical Inventory: No chemicals are stored at the environmental monitoring stations.

Emission History: N/A. No monitoring or sampling of facility effluents has been required, and no historic data exist.

\section{A.3.0 References}

Ballinger, M.Y., S.J. Jette, and M.J. Sula. 1995. Assessment of Unabated Facility Emission Potentials for Evaluating Airborne Radionuclide Monitoring Requirements at Pacific Northwest National Laboratory 1995. PNL-10855, Pacific Northwest Laboratory, Richland, Washington. 
Thompson, C.J., M.Y. Ballinger, E.G. Damberg, and R.G. Riley. 1997. Characterization and Monitoring of 300 Area Facility Liquid Waste Streams During 1994 and 1995. Pacific Northwest National Laboratory, Richland, Washington.

WDOE 1998. A Nonradioactive Air Emissions Notice of Construction for the 306W Building and Catalytic Electorchemical Oxidation Unit for the Department of Energy-RL. DE 98NWP-002. Washington State Department of Ecology. Kennewick, Washington. 
This page intentionally left blank. 


\section{Appendix B}

\section{Supporting Calculations}

\begin{tabular}{|c|c|c|c|c|c|c|c|}
\hline Facility & $\begin{array}{c}\text { Emission } \\
\text { Point }\end{array}$ & $\begin{array}{l}\text { Sampler } \\
\text { Flow, CFM }\end{array}$ & $\begin{array}{c}\text { Stack Flow } \\
\text { CFM }\end{array}$ & $\begin{array}{c}\text { Detectable } \\
\text { Release } \\
\text { Alpha, Ci }\end{array}$ & Beta, Ci & Penetration & Transp. \\
\hline EMSL & EP-3020-01S & 1.7 & 6400 & $1.41 \mathrm{E}-07$ & 5.34E-06 & $90-105$ & 0.9 \\
\hline $305 B$ & EP-305B-01-S & 3.3 & 1000 & $1.06 E-08$ & 4.03E-07 & $96-117$ & 0.96 \\
\hline $306 \mathrm{~W}$ & EP-306W-03-V & 3.1 & 26400 & $3.08 \mathrm{E}-07$ & 1.17E-05 & $93-118$ & 0.93 \\
\hline 318 & EP-318-01-S & 1.7 & 7200 & $1.50 \mathrm{E}-07$ & $5.69 \mathrm{E}-06$ & $95-118$ & 0.95 \\
\hline 320 & EP-320-01-S & 2.7 & 32900 & $5.61 \mathrm{E}-07$ & 2.13E-05 & $73-98$ & 0.73 \\
\hline 320 & EP-320-02-S & 1 & 500 & $2.02 \mathrm{E}-08$ & $7.69 E-07$ & $83-97$ & 0.83 \\
\hline 320 & EP-320-03-S & 1.5 & 440 & $1.22 \mathrm{E}-08$ & 4.63E-07 & $81-103$ & 0.81 \\
\hline 320 & EP-320-04-S & 1.5 & 350 & $9.68 \mathrm{E}-09$ & 3.68E-07 & $81-96$ & 0.81 \\
\hline 323 & EP-323-01-S & 1.5 & 4700 & $1.50 \mathrm{E}-07$ & $5.72 \mathrm{E}-06$ & $70-97$ & 0.7 \\
\hline 326 & EP-326-01-S & 1.5 & 59000 & $1.41 E-06$ & $5.34 \mathrm{E}-05$ & $94-110$ & 0.94 \\
\hline 329 & EP-329-01-S & 3 & 51800 & $6.31 \mathrm{E}-07$ & $2.40 \mathrm{E}-05$ & $92-108$ & 0.92 \\
\hline 3730 & EP-3730-01-S & 2.3 & 340 & $5.18 \mathrm{E}-09$ & $1.97 \mathrm{E}-07$ & $96-102$ & 0.96 \\
\hline 3745 & EP-3745-01-S & 1.5 & 530 & $1.32 \mathrm{E}-08$ & $5.01 E-07$ & $90-98$ & 0.9 \\
\hline MDA alpha & 1 & pCi/sample & & & & & \\
\hline MDA beta & 38 & pCi/sample & & & & & \\
\hline Yr Fraction & 0.04 & 2 wk sample & & & & & \\
\hline Lab Corr Factor & 0.85 & & & & & & \\
\hline Op Factor & 1 & & & & & & \\
\hline Transp. Factor & as given & & & & & & \\
\hline Media Factor & 0.91 & & & & & & \\
\hline Detectable Release & & \multicolumn{6}{|c|}{ n) $\times$ (stack flow/sample flow) $\times 1$ E-12 } \\
\hline
\end{tabular}


This page intentionally left blank. 
PNNL-12160

\section{Distribution}

No. of

Copies

OFFSITE

1 DOE/Office of Scientific and Technical Information

\section{ONSITE}

2 DOE Richland Operations Office

MA Barnard

K8-50

ME Burandt
No. of

Copies

24 Pacific Northwest National Laboratory

BP Atencio

MY Ballinger (3)

P7-68

HL Debban

BSRC

P7-73

AK Ikenberry

P7-79

SL Jones

P7-08

JA Lettau

K9-75

LE Maples

K8-95

KE McMullin

P8-50

CL Nelson

P7-57

CJ Nichols

P7-57

KD Shields (5)

P7-68

Information Release (7)

K1-06

Distr.1 